LA-9223-HDR

UC-66b

Issued: April 1982

LA- $-9223-H D R$

DE82 016129

\title{
Geothermal Investigations in Ohio and Pennsylvania
}

\author{
Yoram Eckstein* \\ Richard A. Heimlich* \\ Donald F. Palmer* \\ Spencer S. Shannon, Jr.
}

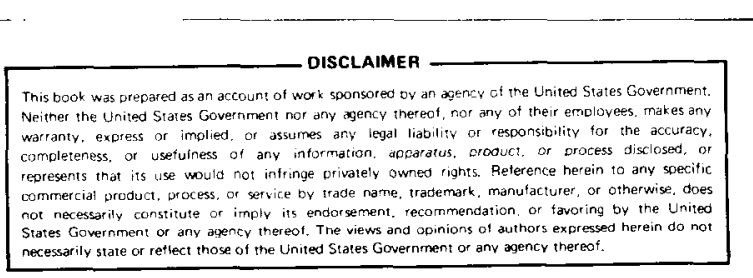

- Department of Geology, Kent State University, Kent, OH 44242. 


\section{DISCLAIMER}

This report was prepared as an account of work sponsored by an agency of the United States Government. Neither the United States Government nor any agency Thereof, nor any of their employees, makes any warranty, express or implied, or assumes any legal liability or responsibility for the accuracy, completeness, or usefulness of any information, apparatus, product, or process disclosed, or represents that its use would not infringe privately owned rights. Reference herein to any specific commercial product, process, or service by trade name, trademark, manufacturer, or otherwise does not necessarily constitute or imply its endorsement, recommendation, or favoring by the United States Government or any agency thereof. The views and opinions of authors expressed herein do not necessarily state or reflect those of the United States Government or any agency thereof. 


\section{DISCLAIMER}

Portions of this document may be illegible in electronic image products. Images are produced from the best available original document. 


\title{
GEOTHERMAL INVESTIGATIONS
}

IN

OHIO AND PENNSYLVANIA

by

\author{
Yoram Eckstein, Richard A. Heimlich, Donald F. Palmer, \\ and Spencer S. Shannon, Jr.
}

\begin{abstract}
New values of heat flow were determined for the Appalachian Plateau in eastern Ohio and northwestern Pennsylvania. Corrected values for wells in Washington and Summit Counties, Ohio, are 1.36 and 1.37 heat-flow units (HFU), respectively. Those of 1.84 and $2.00 \mathrm{HFU}$ define a previously unknown heat-flow high in Venango and Clarion counties, Pennsylvania. Thermal conductivity was measured for core samples from 12 wells in Ohio and 6 wells in Pennsylvania. Heat production was determined for 34 core and outcrop samples from Ohio, Pennsylvania, and New Jersey.
\end{abstract}

\section{INTRODUCTION}

This work was undertaken as part of a program to select sites for hot, dry rock geothermal-energy extraction in the eastern United States. In this study, areas having relatively high conductive heat flow associated with radiogenic heat-producing plutons were sought in ohio and western Pennsylvania. From the geological and geophysical literature, the authors chose areas in which geothermal gradients could be measured in wells, and the thermal conductivity of core samples obtained. From these data they determined the conductive heat flow for four favorable sites. 
GEOLOGY

Figure 1 depicts the geometry of the Precambrian basement surface inferred from 120 wells (Owens, 1967; Saylor, 1968). Subsurface depths to Precambrian rocks range from $<0.6 \mathrm{~km}$ in western Ohio to $>3.6 \mathrm{~km}$ in eastern Ohio and western Pennsylvania.

The Precambrian surface in western Ohio reveals the broad linear Indiana-Ohio platform (Green, 1957), which may be the structural predecessor of the Cincinnati-Findlay Arch. The eastern slope of the basement platform increases eastward from 1 to $20 \mathrm{~m} / \mathrm{km}$ and forms the western margin of the Appalachian Basin. The surface dips to the east in eastern Ohio, and to the south in northwestern Pennsylvania.

In eastern and central Ohio (Fig. 2), and in northwestern Pennysivania (Saylor, 1968), samples from the basement comprise quartz-feldspar gneiss, smaller amounts of quartz-mica schist and amphibolite, and minor occurrences of marble and calcsilicate rocks. The western third of ohio seems to be underlain by Precambrian quartz-feldspar gneiss and granite. Also rhyolite, trachyte, and andesite (McCormick, 1961; Gonterman, 1973) have been identified.

If only the rock in the immediate subcrop is mapped, the underlying rock that may have more geophysical significance is ignored. Although Summerson (1962) maps an area underlying Guernsey County, Ohio, as granitic gneiss, only the upper $3 \mathrm{~m}$ are gneiss, whereas the next $81 \mathrm{~m}$ are amphibolite (McCormick, 1961). In this study, the dominant lithology is mapped and a single pattern is used for medium to coarse quartzo-feldspathic rocks. The mapped area of some rock types has been decreased around drill-hole sites. A newly identified area of granite (M. F. Schmidt, personal communication) in Morrow County has been added to the Ohio map.

Precambrian rocks crop out only in southeastern Pennsylvania. Granite, diorite, gabbro, and anorthosite are associated with granitic gneiss, paragneiss, and metavolcanic rocks (Gray and Shepps, 1960). Throughout the rest of the state they are identified from cores and cuttings and by interpretation of geophysical data. Rocks in the basement in Ohio and northwestern Pennsylvania are similar to those in Precambrian outcrops in Pennsylvania. However, anorthosite has been reported only in southeastern Pennsylvania.

The basement in Ohio and western Pennsylvania may be an extension of the Grenville belt based on radiometric age determinations (Bass, 1960; Rudman et 


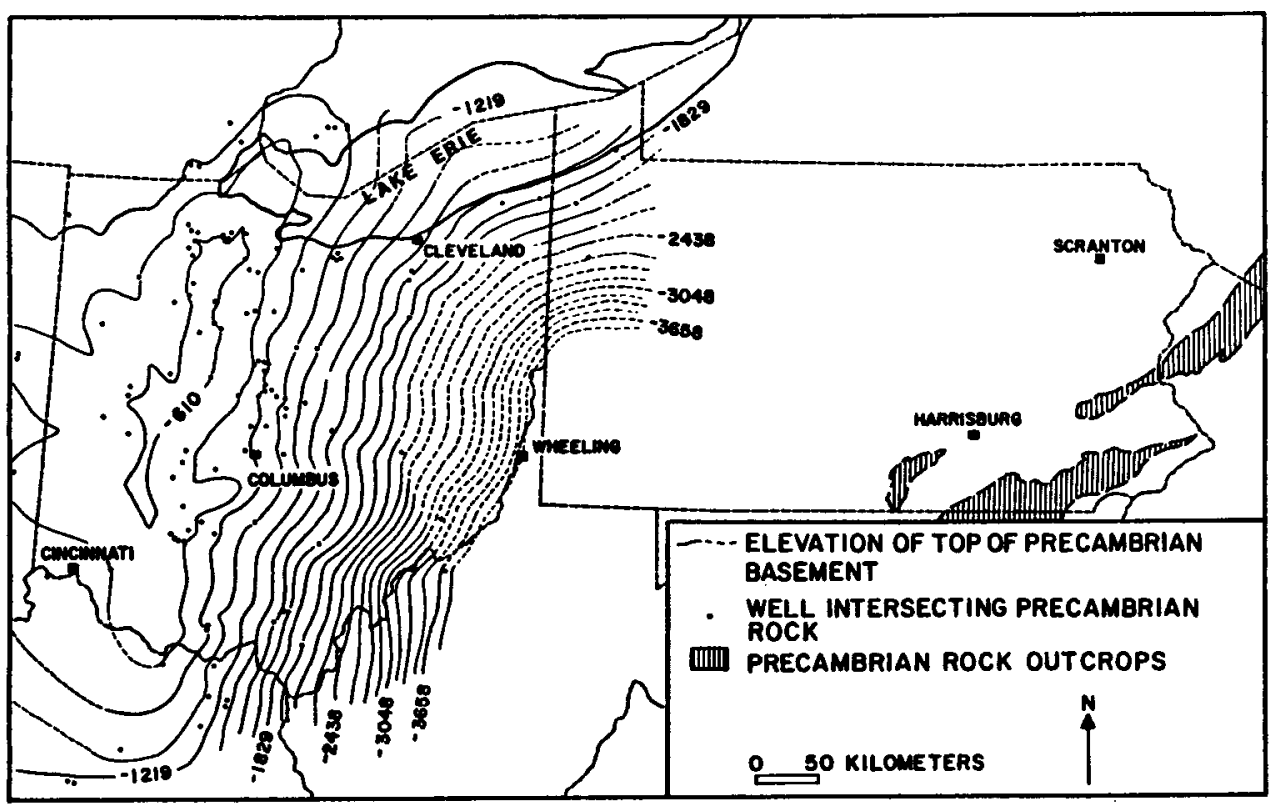

Fig. 1 .

Elevation of top of Precambrian basement in Ohio and Pennsylvania (from Owens, 1967 and Saylor, 1968).

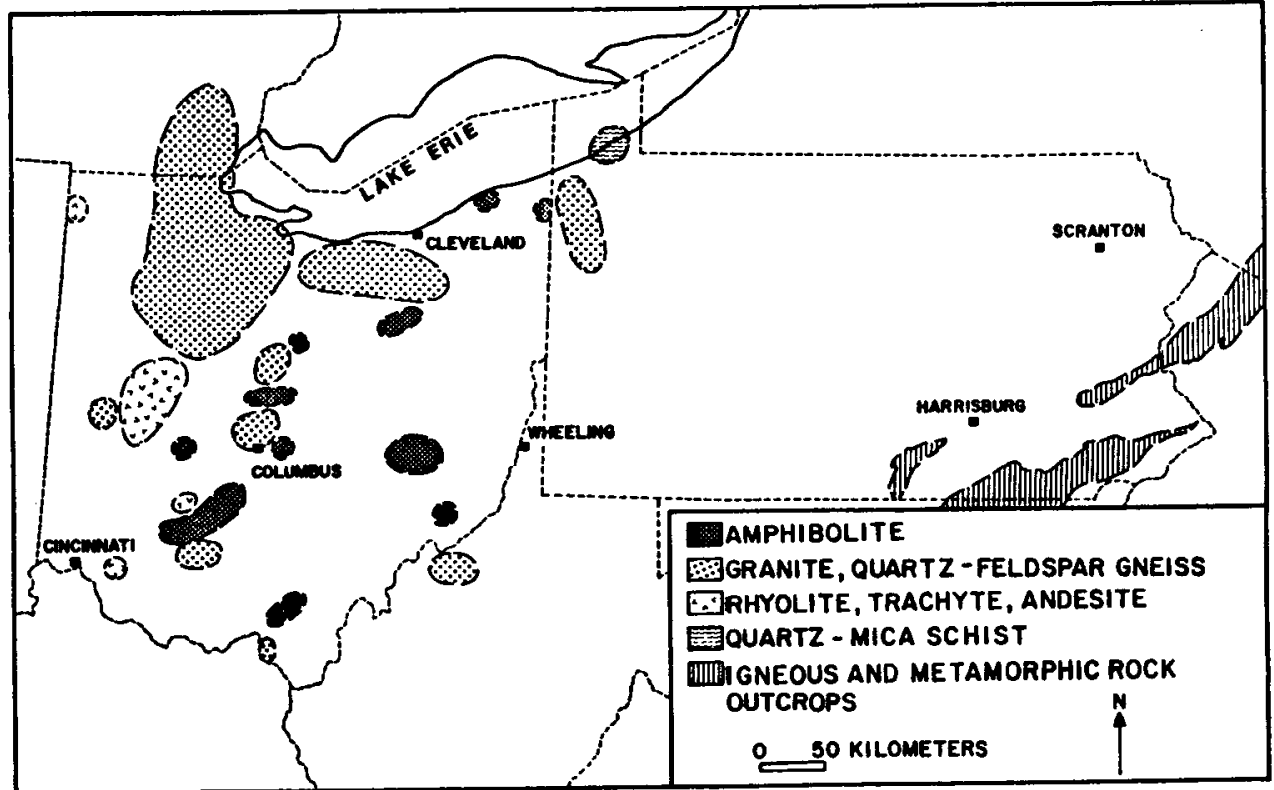

Fig. 2 .

Precambrian rock types in Ohio and Pennsylvania (from McCormick, 1961; Summerson, 1962; Saylor, 1969; and Ross, 1972). 
a1., 1965; Lidiak et a1., 1966; Hofmann et al., 1972; Lapham, 1975; Barbis, 1978). Rb-Sr and K-Ar ages determined on biotite and muscovite from such rocks in Ohio and on whole rock samples from Pennsylvania range from 837 to 942 Myr. Exceptions are whole-rock Rb-Sr ages (1242 and $1304 \mathrm{Myr}$ ) for two Ohio trachyte and rhyolite samples (Lidiak et al., 1966; Barbis, 1978), and $\mathrm{Rb}-\mathrm{Sr}$ feldspar ages for four ohio gneiss and granite samples, which range from 1118 to 1406 Myr (Barbis, 1978).

Barbis (1978) concludes that the Precambrian basement in Ohio was metamorphosed during the Grenville orogeny $1171 \pm 36$ Myr ago. The distribution of basement ages rules out an earlier conclusion (Bass, 1960) that the Grenville Front extends southward from Canada through western Ohio. The trachyte and rhyolite dates indicate that volcanism occurred about $1280 \mathrm{Myr}$ ago. All basement rocks in Ohio and western Pennsylvania have Precambrian ages.

The Precambrian basement is overlain by Paleozoic sedimentary rocks that range in thickness from $<0.6 \mathrm{~km}$ in western ohio to $>5.5 \mathrm{~km}$ in southeastern Pennsylvania. The Paleozoic stratigraphy is described by Shearrow (1957) and Collins (1979). The dominant rock types are:

System

Permian

Pennsylvanian

Mississippian

Devonian

Silurian

Ordovician

Cambrian

\section{Lithology}

Sands tone

Sandstone, shale, limestone, coal

Sandstone, siltstone, shale

Limestone, shale

Sands tone, carbonate rocks, evaporite Carbonate rocks

Sands tone

Cambrian and Ordovician schist, gneiss, quartzite, and serpentinite crop out in southeastern Pennsylvania. In the same area, Triassic shales and sandstones are intruded by diabase dikes. Pleistocene moraines overlie much of the bed rock in the northern parts of Ohio and Pennsylvania.

In the Plateau structural province, which includes ohio and western Pennsylvania, flat-lying Paleozoic rocks locally have gentle folds. Low re- 
gional dips of the Paleozoic rocks in Ohio are related to the Cincinnati Arch (Fig. 3) where uplift began no earlier than Silurian time (Scotford, 1964).

In the Valley and Ridge Province in central Pennsylvania, the Paleozoic rocks were deformed by intensive folding and thrust faulting. In southeastern Pennsylvania, the structural features in metamorphic rocks of the Piedmont Province are partially obscured by sedimentary and volcanic rocks in Triassic grabens.

GEOPHYSICAL SURVEYS

Sources of gravity data include surveys of Ohio (Heiskanen and Uotila, 1956), Pennsylvania (Diment et al., 1972), and the United States (Woollard and Joesting, 1964). Gravity data for the area are mapped in Fig. 4.

The region has generally negative Bouguer gravity values that are characteristic of continents. In easternmost Ohio and western Pennsylvania there are slight fluctuations in gravity values. Prominent anomalies occur in central and western Ohio and in central and eastern Pennsylvania. The longer wavelengths and more subdued anomalies in eastern Ohio may be related to the increased depth to the basement (Rudman et a1., 1965) or to greater homogeneity of the basement rocks (Summerson, 1962). Because the basement in western Ohio has more granite interspersed with metamorphic rocks, density of the terrain is more heterogeneous. Pincus (1960) concluded from an analysis of five major Bouguer anomalies in Ohio that they are caused by density contrasts within the Precambrian basement complex.

Positive anomalies in northwestern ohio have amplitudes and wavelengths of $40 \mathrm{mgal}$ and $25 \mathrm{~km}$ in Sandusky and Seneca Counties, $10 \mathrm{mgal}$ and $25 \mathrm{~km}$ in Lucas and Wood Counties, and $30 \mathrm{mgal}$ and $50 \mathrm{~km}$ in Auglaize, Shelby, and Miami Counties (Newhart, 1975; Haidarian, 1976; Williams, 1976; and Quick, 1976). A large negative anomaly studied by Haidarian (1976) has an amplitude of 25 mgal and a wavelength of $65 \mathrm{~km}$. The positive anomalies seem to be related to gabbro or amphibolite masses in the crust, whereas the negative anomaly may be related to a deeper granite pluton. However, the petrology deduced from gravity values does not agree with cores of basement rocks (McCormick, 1961; Summerson, 1962). Although the high-amplitude Bouguer anomaly and magnetic anomaly in Sandusky and Seneca Counties are thought to result from mass of amphibolite, a drill hole intercepted granite. However, the bodies outlined 


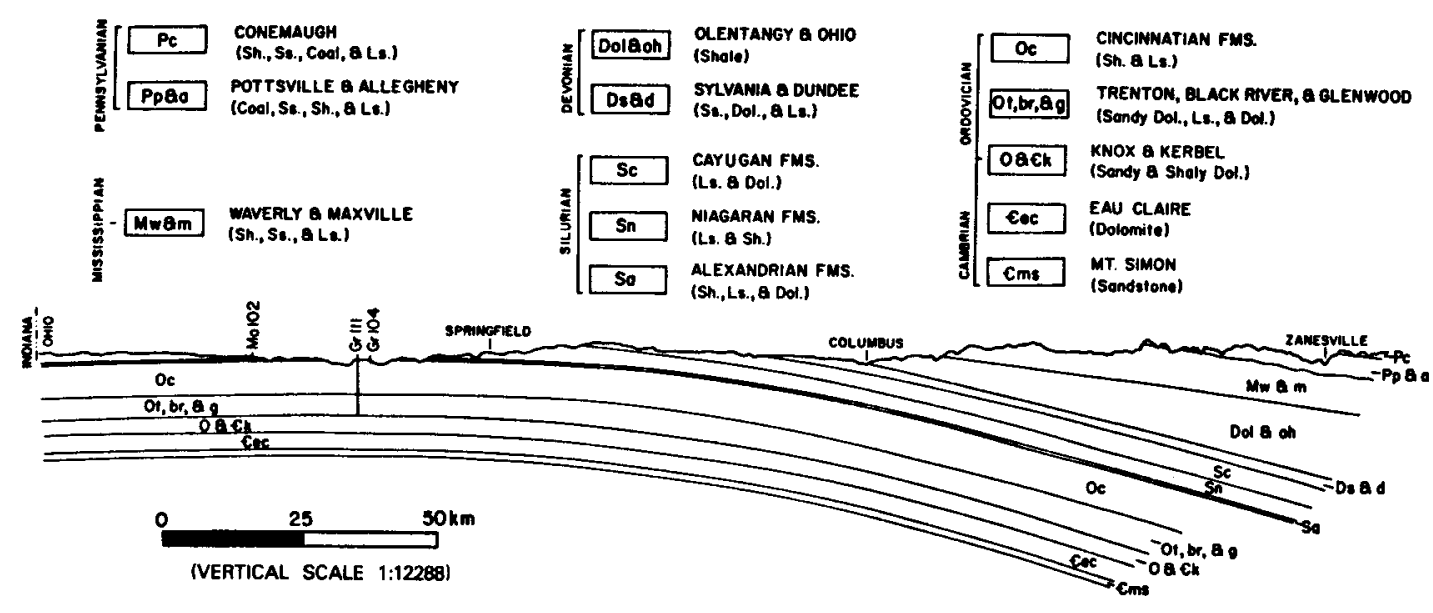

Fig. 3 .

Generalized stratigraphic section across the Cincinnati-Findlay Arch in western Ohio.

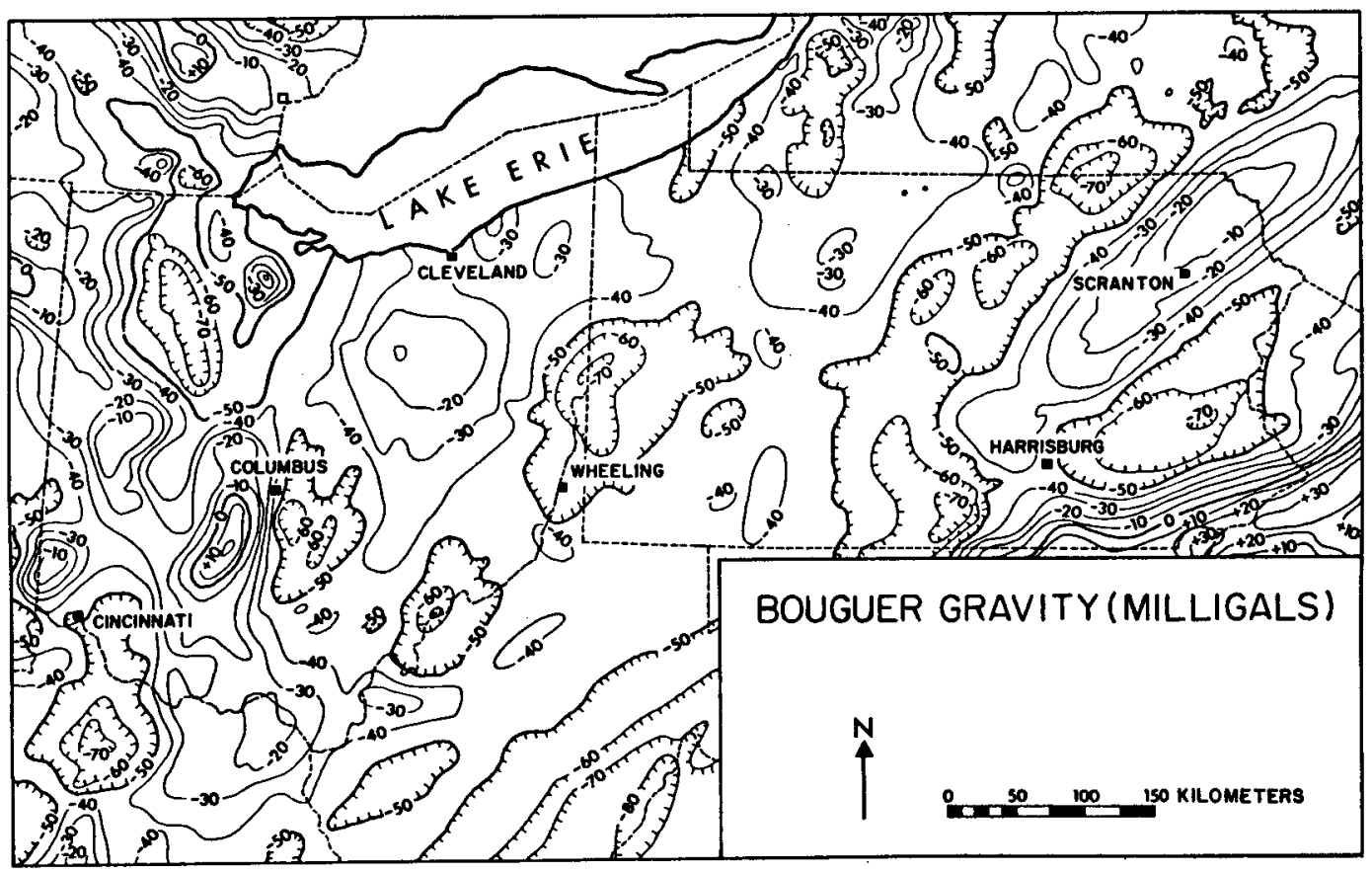

Fig. 4 .

Bouguer gravity map of Ohio and Pennsylvania (modified after Heiskanen and Uotila, 1956; Wollard and Joestling, 1964; and Diment et al., 1972). 
by the gravity anomalies may be deep within the Precambrian basement. All large-scale anomalies in Fig. 4 indicate density variations in the basement complex. Wallace's (1978) measurement of gravity at 450 stations shows a regional gradient identical to that in northeastern Ohio.

In Pennsylvania, large Bouguer anomalies are related to deep sources as in Ohio (Duecker, 1954; Diment et al., 1972) and to shallow diabase intrusions (Kane, 1961). The anomalies in Fig. 4 are due to sources within the basement, which is deep in much of Pennsylvania. In eastern Pennsylvania, the Scranton gravity high is flanked by negative troughs. The Scranton gravity high may result from an excess mass emplaced within the basement complex in Precambrian time (Diment et al., 1972).

Magnetic anomalies associated with gravity anomalies in Ohio have low relief and low gradients that may result from deep basement sources. In Pennsylvania, magnetic anomaly patterns are smooth over areas underlain by Paleozoic sedimentary rocks, but they have high gradients over areas underlain by Precambrian basement or later intrusions. Interpretations of sources causing such anomalies are consistent with models by Haidarian (1976), Quick (1976), Diment et a1., (1972), and Rudman et a1., (1965).

Seismic studies in Ohio and Pennsylvania have determined crustal and upper-mantle velocity structures, depths to the Mohorovicic discontinuity, and sub-Moho layering (Woollard, 1972; Diment et al., 1972). Detailed studies are limited and do not show indications of recent magmatic activity.

The seismicity of Ohio and Pennsylvania is illustrated in Fig. 5. Two zones of moderate seismic activity are separated by a zone of quiescence in southeastern Ohio and western Pennsylvania.

Other seismic areas are in western and northern Ohio. The most active part is the Anna earthquake zone near the bifurcation of the Findlay and Kankakee arches (Bradley and Bennett, 1965). The western Ohio earthquake zone is along the trend of the New Madrid fault zone in Missouri and thus may be related to it.

Earthquake activity along Lake Erie in northern Ohio has been related to seismicity in northwestern New York and in the valley of the St. Lawrence River (Bradley and Bennett, 1965; Spal1; 1979). Some recent seismicity may result from reactivation of basement faults (York and 01iver, 1976).

Seismic activity in eastern Pennsylvania seems to be a northeastern extension of the seismic zone of the southern Appalachians. It has been 


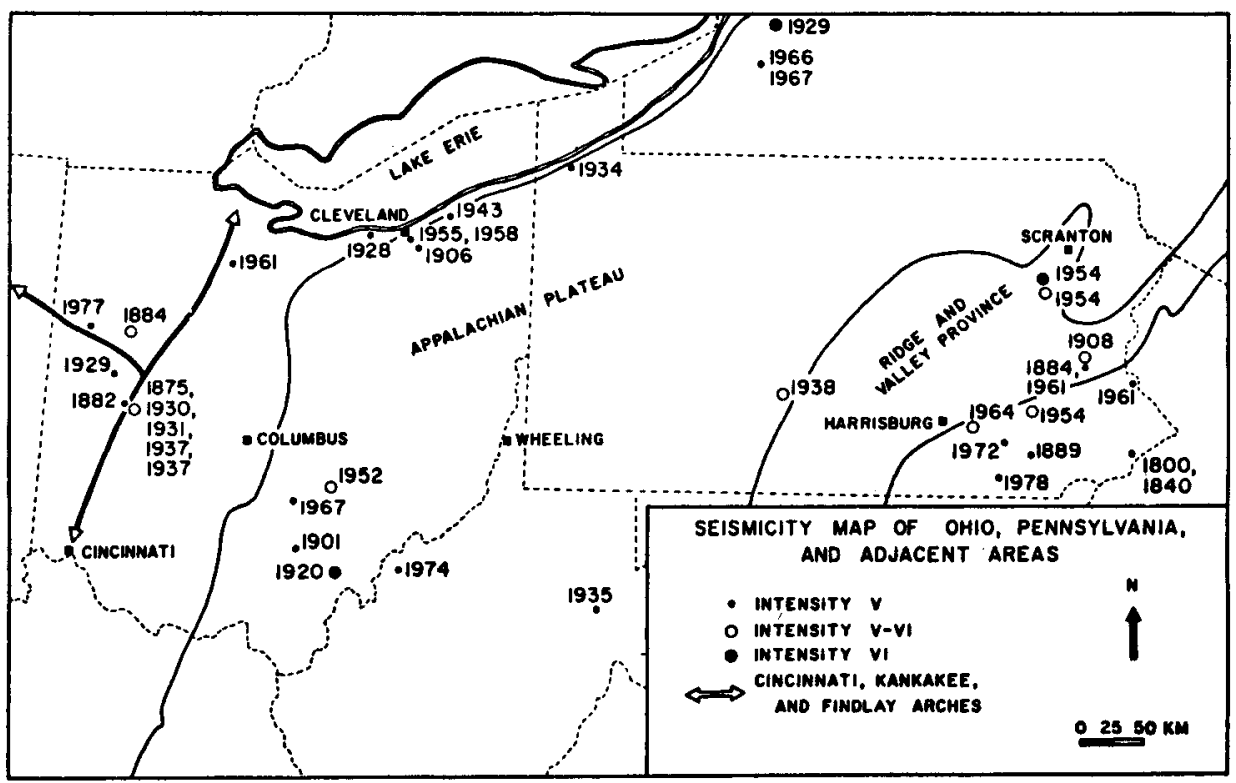

Fig. 5 .

Seismicity map of Ohio, Pennsylvania, and adjacent areas.

inferred that slow uplift in the Appalachian region has continued along older faults that have been reactivated (Woollard, 1958; Bollinger, 1973).

GEOTHERMAL REGIME

Research has focused on updating the temperature gradient map of Ohio and Pennsylvania (American Association of Petroleum Geologists and U.S. Geological Survey) and generation of heat-flow data.

The geothermal-gradient map of Ohio (Fig. 6) is based on bottom-hole temperature (BHT) readings from $2910 i 1$ and gas production or exploration wells (App. A). The gradient map for Pennsylvania (Fig. 7) is based on BHT readings from 533 wells (App. B). Geothermal gradients were computed by subtracting the temperature of shallow ground water ( $\left.T_{g w}\right)$ (Figs. 8 and 9) (Water Well Journal, 1979) from the BHT readings, assuming a depth of $30.5 \mathrm{~m}$ for the $T_{g w m}$, and dividing the difference by the depth at which BHT readings were taken, reduced by $30.5 \mathrm{~m}$. BHT readings were corrected for the time each reading was taken after drilling-fluid circulation had stopped and for the depth of the reading. The correction is based on an approximation of the graphical solution presented by Kappelmeyer and Haenel (1974). The resulting 


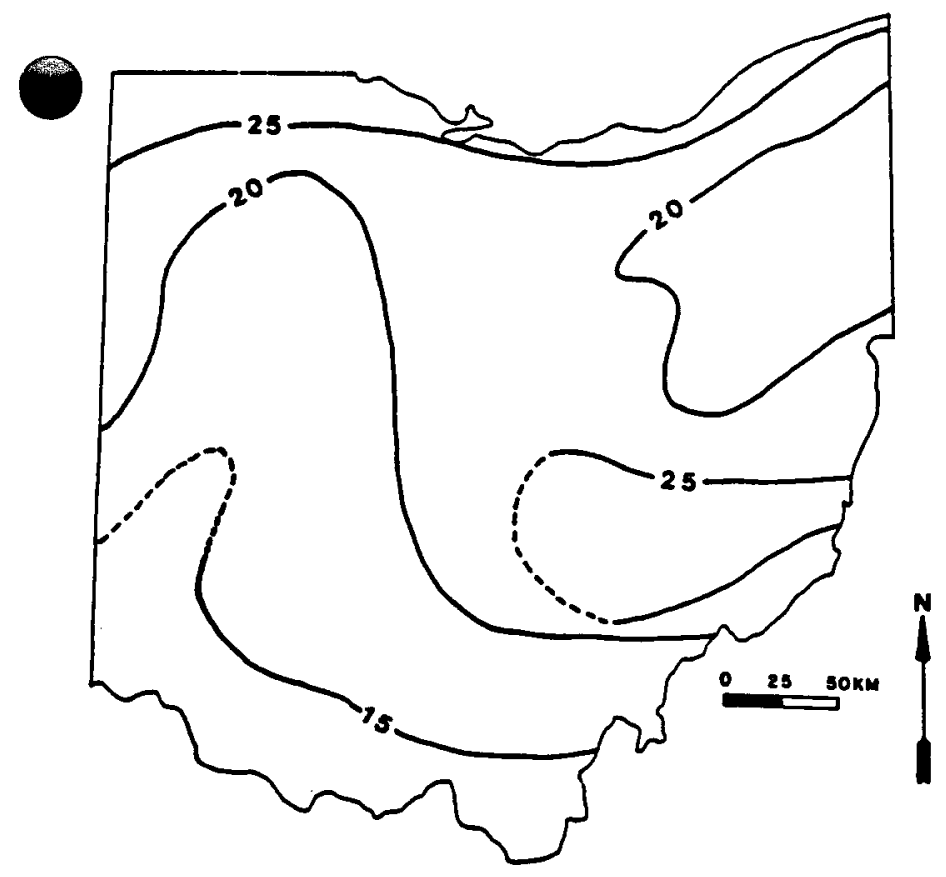

Fig. 6

Geothermal gradient map of Ohio $\left({ }^{\circ} \mathrm{C} / \mathrm{km}\right)$.

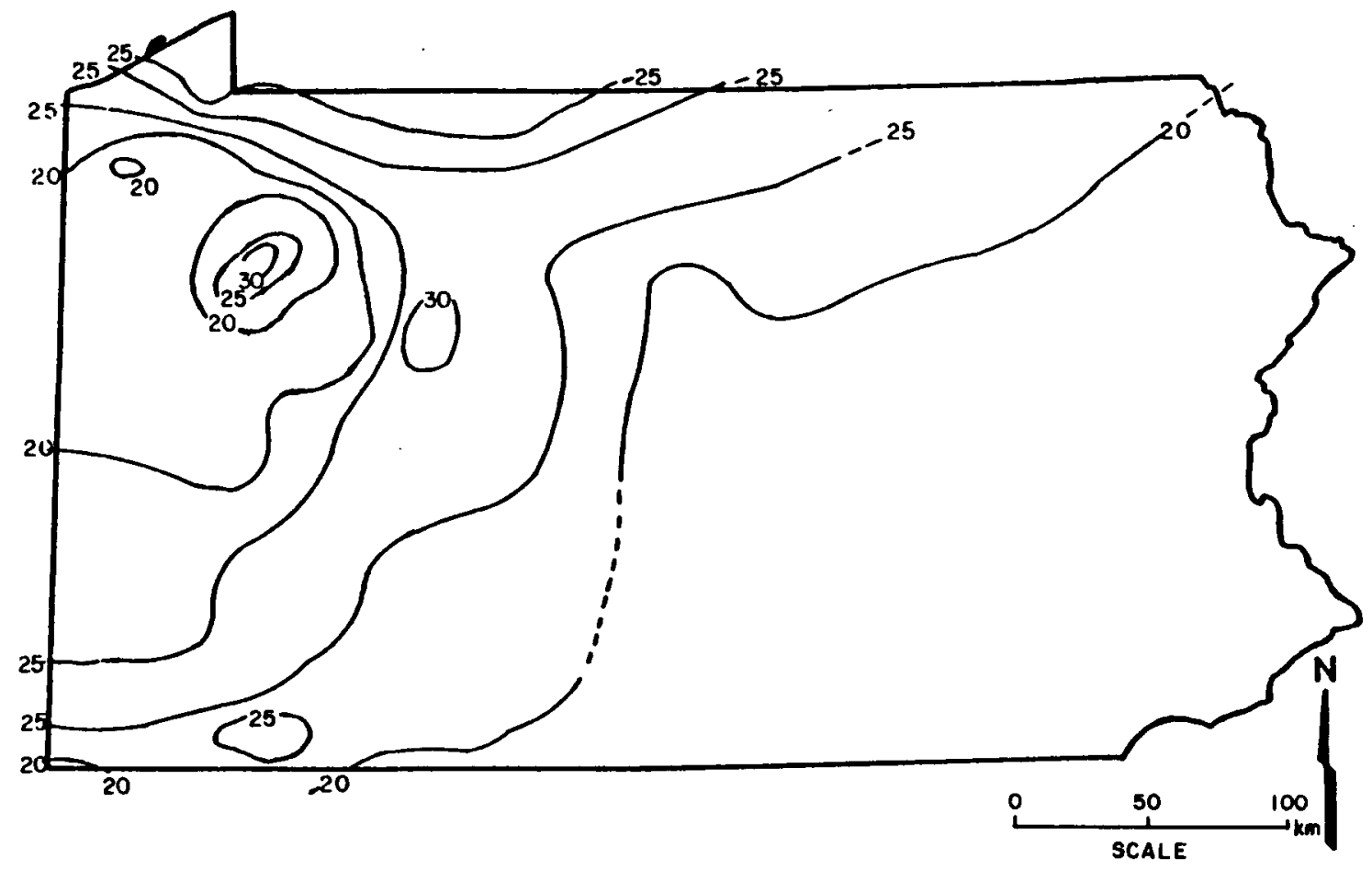

Fig. 7.

Geothermal gradient map of Pennsylvania $\left({ }^{\circ} \mathrm{C} / \mathrm{km}\right)$. 


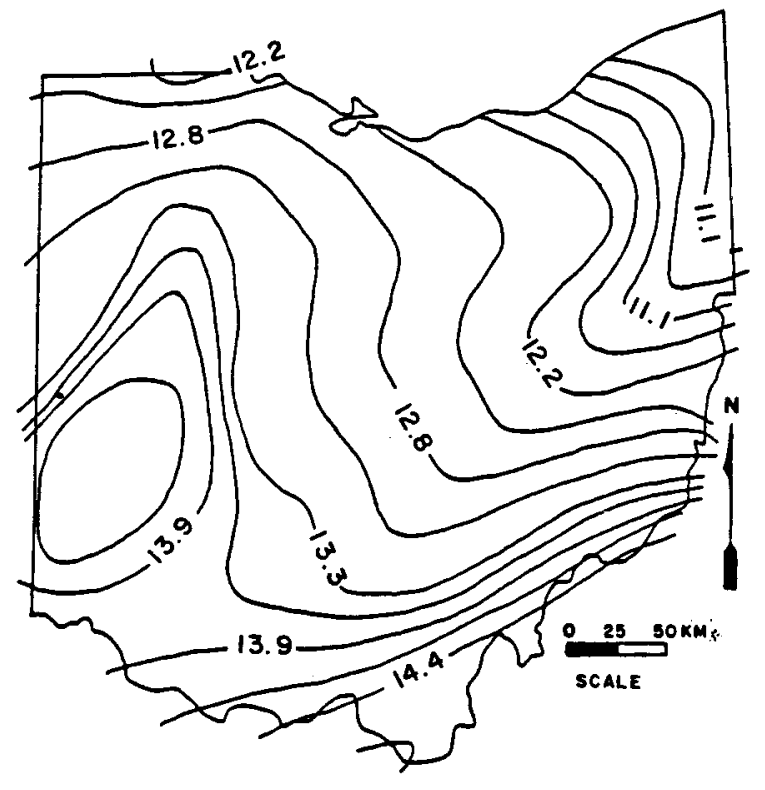

Fig. 8 .

Temperatures $\left({ }^{\circ} \mathrm{C}\right)$ of ground water in Ohio at depth of $30.5 \mathrm{~m}$ (modified after Water Well Journal, 1979).

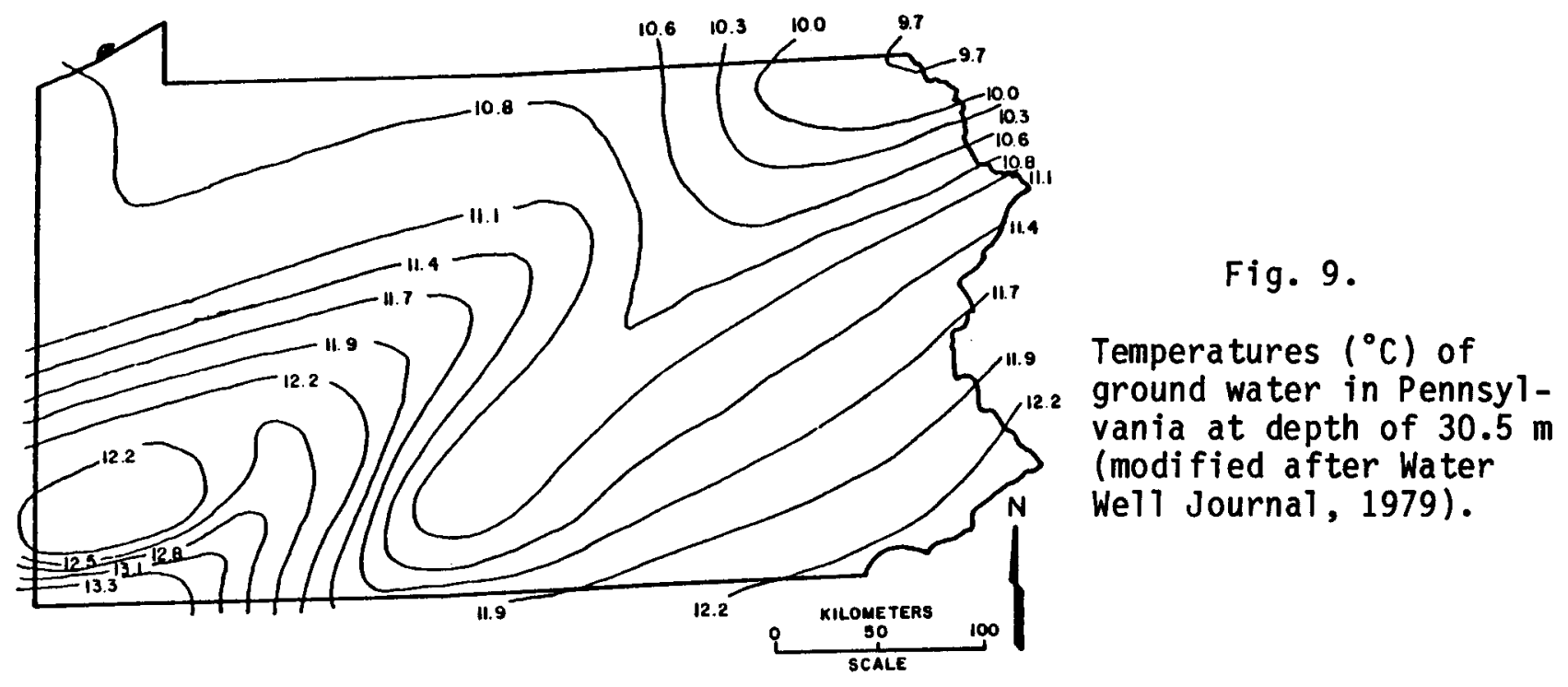

corrected gradients may be accurate within $\pm 2^{\circ} \mathrm{C} / \mathrm{km}$. This error results primarily from a lack of information concerning the elapsed time between cessation of the mud circulation and temperature logging.

Some differences between the geothermal-gradient and ground-water temperature maps are noted in Ohio and Pennsylvania. Ground-water temperatures in shallow $(15-45 \mathrm{~m})$ aquifers are determined by the shallow geothermal gradient and the ground-water recharge system. Convection causes redistribution of the conductive heat flow in both regimes. Its effect is greatest in regions of 
high relief and intense faulting, where recharge by precipitation at higher altitudes maintains constant ground-water movement toward discharge areas. Where the heat-transfer effects at shallow and moderate depths are greatest, the differences in the geothermal-gradient and ground-water temperatures are largest.

Acquisition of new information on the geothermal gradient was limited by the availability of wells suitable for direct measurements. Depth-temperature profiles obtained from a number of wells that intercepted aquifers in Ordovician dolomites in western ohio could not be used because some depth intervals have temperature inversions or near-zero temperature gradients, possibly from convective heat transfer. As there has been little past or present drilling in central and eastern Pennsylvania, few wells were available. Temperatures were measured at discrete intervals using a thermistor probe, which was calibrated to $\pm 0.02^{\circ} \mathrm{C}$.

\section{Corrections}

Most heat-flow measurements are made in shallow (2-km) wells that were not drilled for geothermal purposes. Where temperatures have been perturbed near the earth's surface, corrections must be applied to remove the effects of paleoclimatic variations, surface topography, and surface drainage. Because these temperature corrections are cumulative and depth- and time-dependent, the most recent perturbation should be removed first and the oldest last.

The largest temperature correction is the removal of the effects of Quarternary climatic variations. Past 7ong-term changes in mean surface temperature have produced significant changes at depth (Birch, 1948). Pleistocene glacial stages decreased the mean surface temperature whereas interglacial stages increased it. The overall effect has been a decrease in the observed geothermal gradient.

A mathematical model of surface-temperature history may be approximated by a step function that defines the deviation from mean surface temperature with time. The model that best represents paleoclimatic effects in onio and Pennsylvania (Table I) is a composite of the step functions proposed by Birch (1948), Urban (1971), Diment et al., (1972), and Cermak (1976). The cor-

rection for temperature increase during the Holocene epoch (Cermak, 1976) decreases the paleoclimatic correction below previously reported values (Urban, 1971; Diment et al., 1972; Schlorholtz, 1979). Step changes are 
considered instantaneous (Birch, 1948). Three values of thermal diffusivity were used to approximate the maximum $\left(\kappa=0.016 \mathrm{~cm}^{2} / \mathrm{sec}\right)$, minimum $(\kappa=0.008$ $\left.\mathrm{cm}^{2} / \mathrm{sec}\right)$, and mean $\left(\mathrm{k}=0.010 \mathrm{~cm}^{2} / \mathrm{sec}\right)$ values expected (Birch, 1948; Urban, 1971).

Surface topography and previous episodes of uplift and erosion may affect near-surface geothermal gradients. The effects of surface topography

\section{TABLE I}

STEP FUNCTION DEF INING THE PALEOCLIMATIC MODEL FOR NORTHWESTERN PENNSYLVANIA ${ }^{a}$

\begin{tabular}{c}
$\begin{array}{c}\text { Time } \\
(y r)\end{array}$ \\
\hline $0-20$ \\
$20-50$ \\
$50-100$ \\
$100-150$ \\
$150-200$ \\
$200-400$ \\
$400-500$ \\
$500-600$ \\
$600-700$ \\
$700-800$ \\
$800-900$ \\
$900-1000$ \\
$1000-2000$ \\
$2000-3000$ \\
$3000-4000$ \\
$4000-5000$ \\
$5000-6000$ \\
$6000-7000$ \\
$7000-8000$ \\
$8000-9000$ \\
$9000-10000$
\end{tabular}

Deviation From Present Mean Surface Temperature $\left({ }^{\circ} \mathrm{C}\right)$

0.0

$+2.5$

$+2.0$

$+1.5$

0.0

$-1.0$

$-0.5$

0.0

$+0.5$

$+1.0$

$+2.0$

$+1.0$

0.0

$+0.5$

$+1.25$

$+0.75$

$+2.25$

$+2.5$

$+1.75$

$+1.5$

$-0.5$ 
Tabie I (cont)

\begin{tabular}{ccc}
$\begin{array}{c}\text { Time } \\
(y r)\end{array}$ & $\begin{array}{c}\text { Deviation From Present Mean } \\
\text { Surface Temperature } \\
\left({ }^{\circ} \mathrm{C}\right)\end{array}$ \\
\cline { 2 - 3 } $10000-20000$ & -5.0 \\
$20000-30000$ & -10.0 \\
$30000-40000$ & 0.0 \\
$40000-60000$ & -10.0 \\
$60000-80000$ & 0.0 \\
$80000-100000$ & -10.0 \\
$100000-200000$ & +2.0 \\
$200000-300000$ & -10.0 \\
$300000-600000$ & +2.0 \\
$600000-700000$ & -10.0 \\
$700000-900000$ & +2.0 \\
$900000-$ & 0.0 \\
\hline a(Birch, 1948; Urban 1971; Diment et al., 1972; Cermak, 1976)
\end{tabular}

are removed by adjusting measured temperatures to corrected values below a horizontal datum at the collar of the well. An area within a 20-km radius of each well was integrated in the steady-state topographic correction (Birch, 1950). There have been only minor amounts of uplift and erosion within the study area since early Paleozoic time (Willard, 1962), so no correction was necessary for these factors.

If a river is considered as a line heat source (or sink) of infinite length, the temperature disturbance introduced into shallow strata by a river is defined by

$$
T(x, y, z)=\frac{z T_{0}}{2 \pi} \int_{-\infty}^{\infty} d x^{\prime} \int_{-L}^{0} d y^{\prime} /\left(x-x^{\prime}\right)^{2}+\left(y-y^{\prime}\right)^{2}+z^{2} 3 / 2,
$$

where To is the temperature difference in ${ }^{\circ} \mathrm{C}$ between the mean annual temperature of the river and that of the surrounding soil. $L$ is the width of the river in meters and $1 /\left(\left(x-x^{\prime}\right)^{2}+\left(y-y^{\prime}\right)^{2}+z^{2}\right)^{3 / 2}$ is the distance 
weighting factor (Monge11i, 1970). The mean annual soil temperature was assumed to equal the mean annual air temperature. This approximation is valid for areas of low to moderate elevation (Mongelli, 1970).

Ohio

The most distinctive feature of the onio ground-water temperature map (Fig. 9) is the northward-trending high, along the Cincinnati Arch in the western part of the state. However, the geothermal-gradient map has a slight negative correlation coincident with the arch. Because the lithology of the gently dipping Phanerozoic strata is fairly uniform throughout ohio and western Pennsylvania, shallow subsurface variations in the geothermal regime, cannot readily be attributed to lateral variations in thermal conductivity of the rocks. Moreover, the regional topography is nearly flat. Therefore, the higher temperature of the ground water coincident with the Cincinnati Arch may result from deeper convective ground-water movement along faults and vertical fractures. A similar high ground-water temperature anomaly in southwestern Pennsylvania trends southwestward through West Virginia and into the southernmost counties of ohio. Cannon et al. (1980) proposed a conceptual model for a convective system generating an anomaly in shallow glacial formations. The general principle of the model may be applied as well to two deep, confined aquifers separated by a fractured lithologic unit having aquiclude characteristics, such as a shale or marl. Convection through the fractures would short-circuit between the two aquifers. A well drilled directly above such a convection current would have an anomalously high temperature gradient. A well drilled into such a convection system away from a rising current would have an anomalously low temperature gradient. An analysis of the depthtemperature profiles and depth-geothermal-gradient profiles calculated on the basis of the distribution of BHT throughout ohio tends to support the validity of the model. The depth-BHT diagram for wells along the Cincinnati Arch has a wide scatter of points (Fig. 10), whereas similar diagrams for areas east and west of the arch show arrays of points along a fairly consistent slope (Figs. 11-15). Likewise, the depth-geothermal-gradient diagram for wells along the arch has a wide scatter of the points, particularly in the shallow zones (Fig. 16), whereas the same diagrams for the regions east and west of the arch show a fairly consistent geothermal gradient for most depths, within the range from $15^{\circ} \mathrm{C} / \mathrm{km}$ to $30^{\circ} \mathrm{C} / \mathrm{km}$ (Figs. 17-20). 


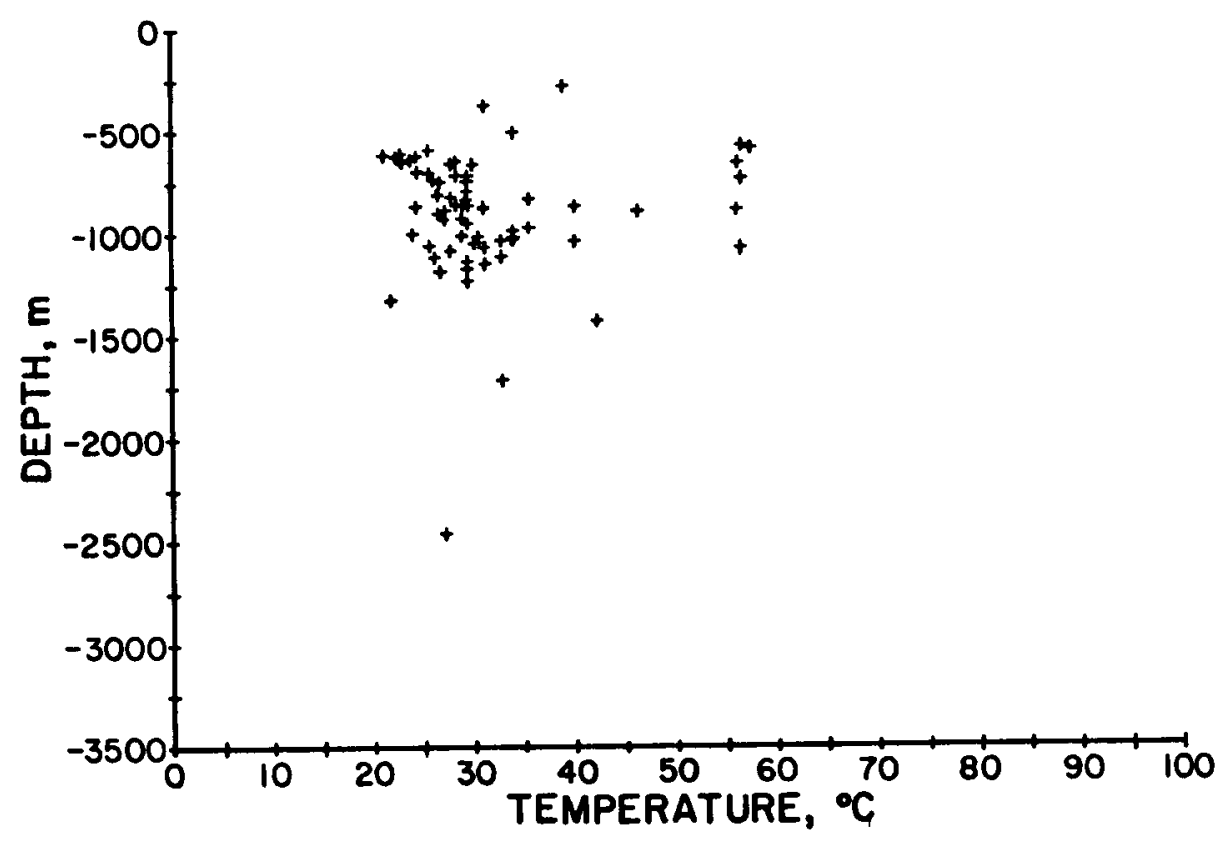

Fig. 10.

BHT in wells along the Cincinnati-Findlay Arch in western Ohio.

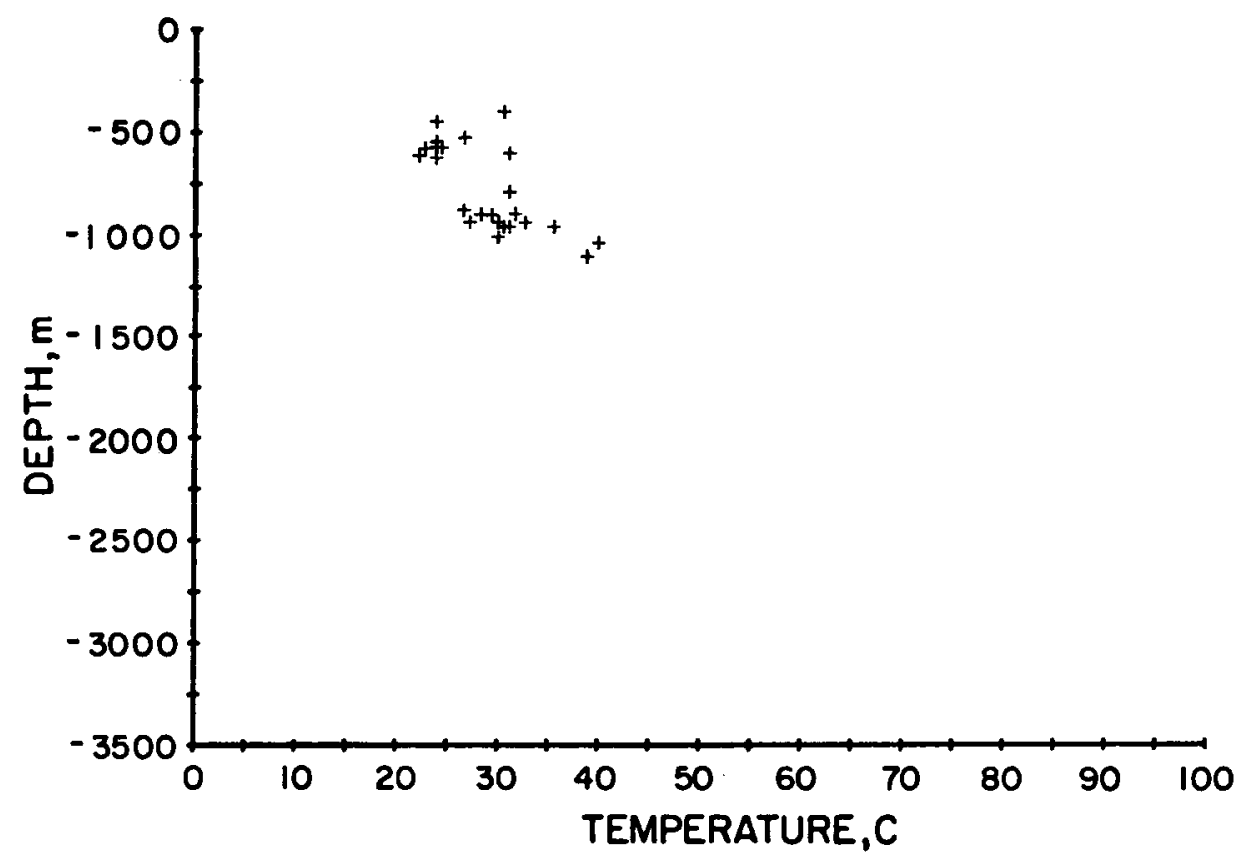

Fig. 11 .

BHT in wells on the western flank of the CincinnatiFindlay Arch in western Ohio. 


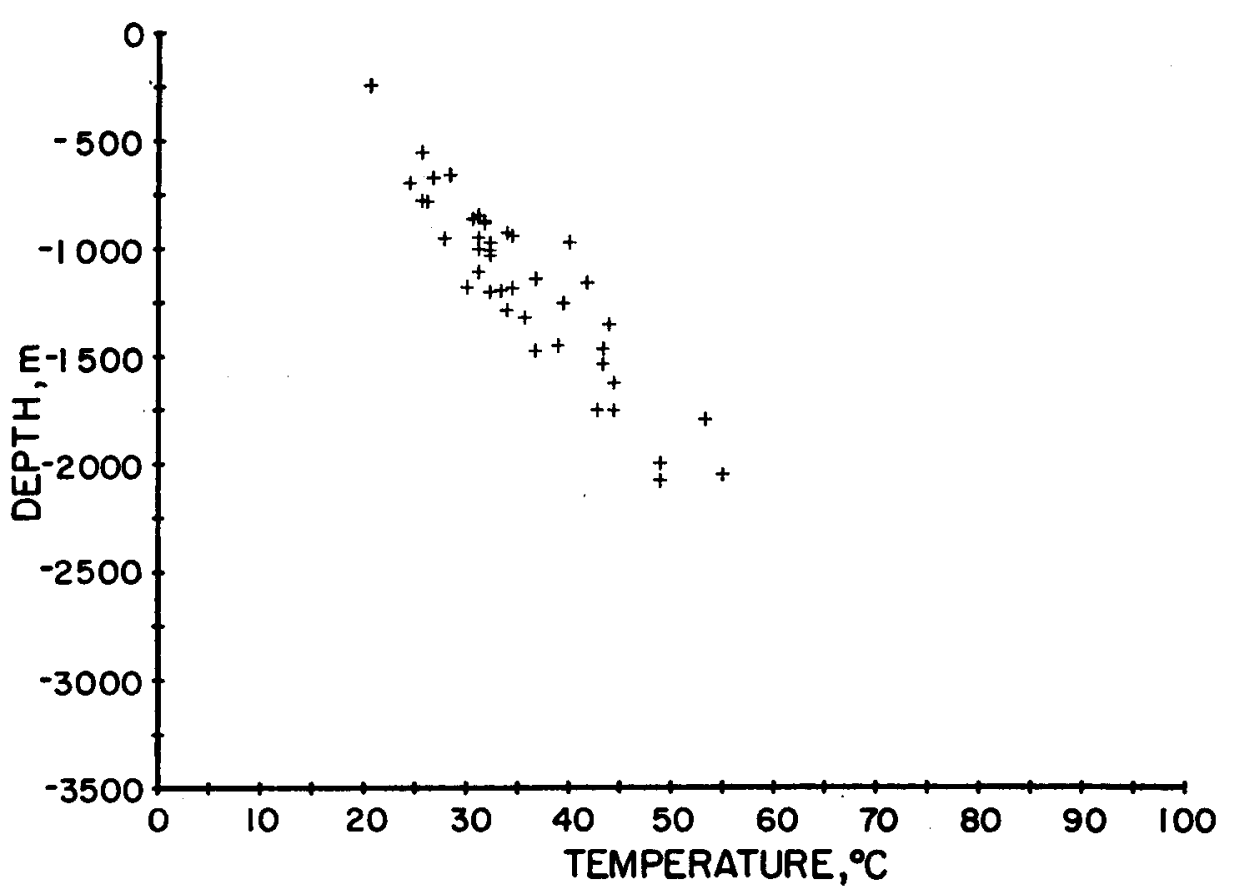

Fig. 12 .

BHT in wells on the eastern flank of the CincinnatiFindlay Arch in central Ohio.

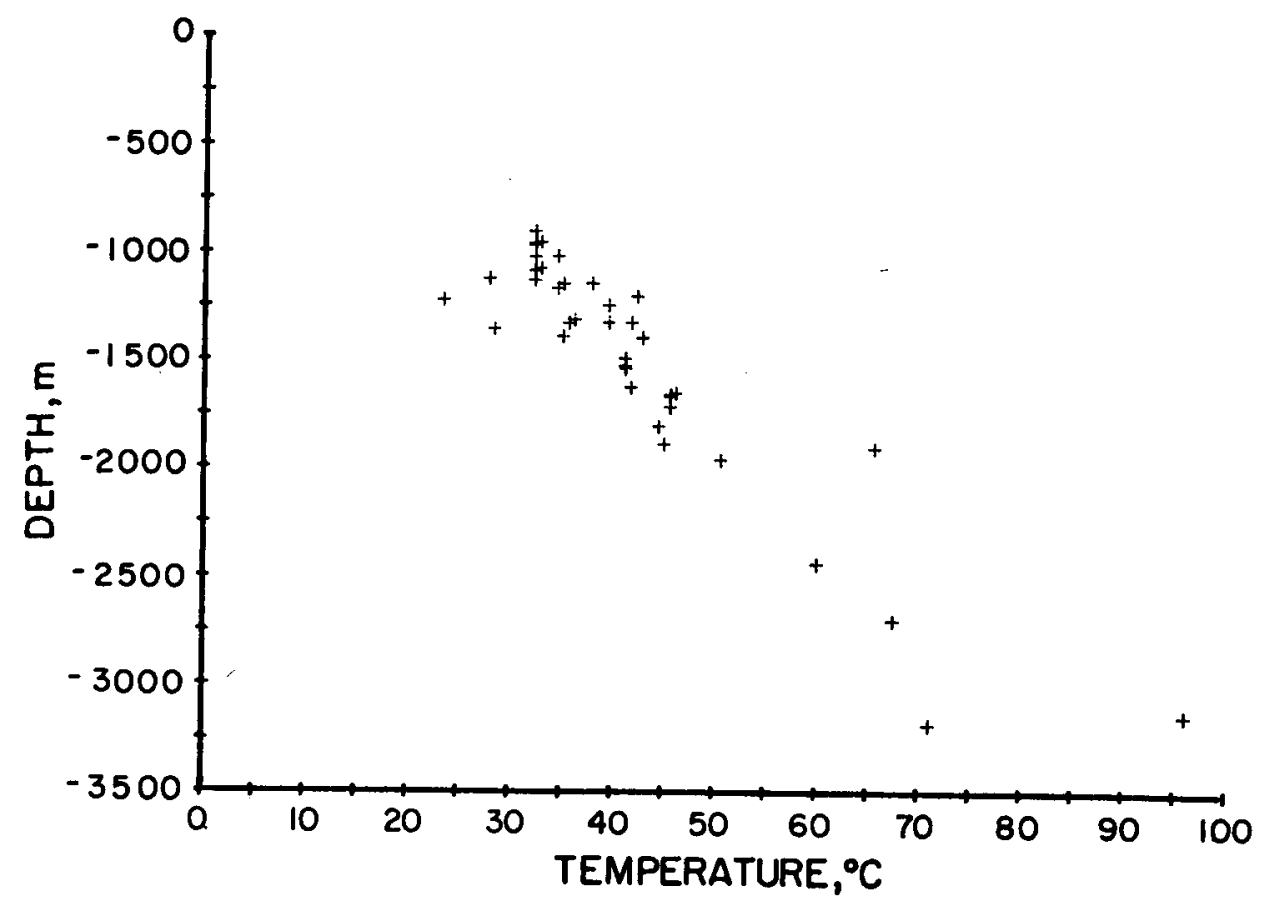

Fig. 13 .

BHT in wells in northeastern Ohio. 


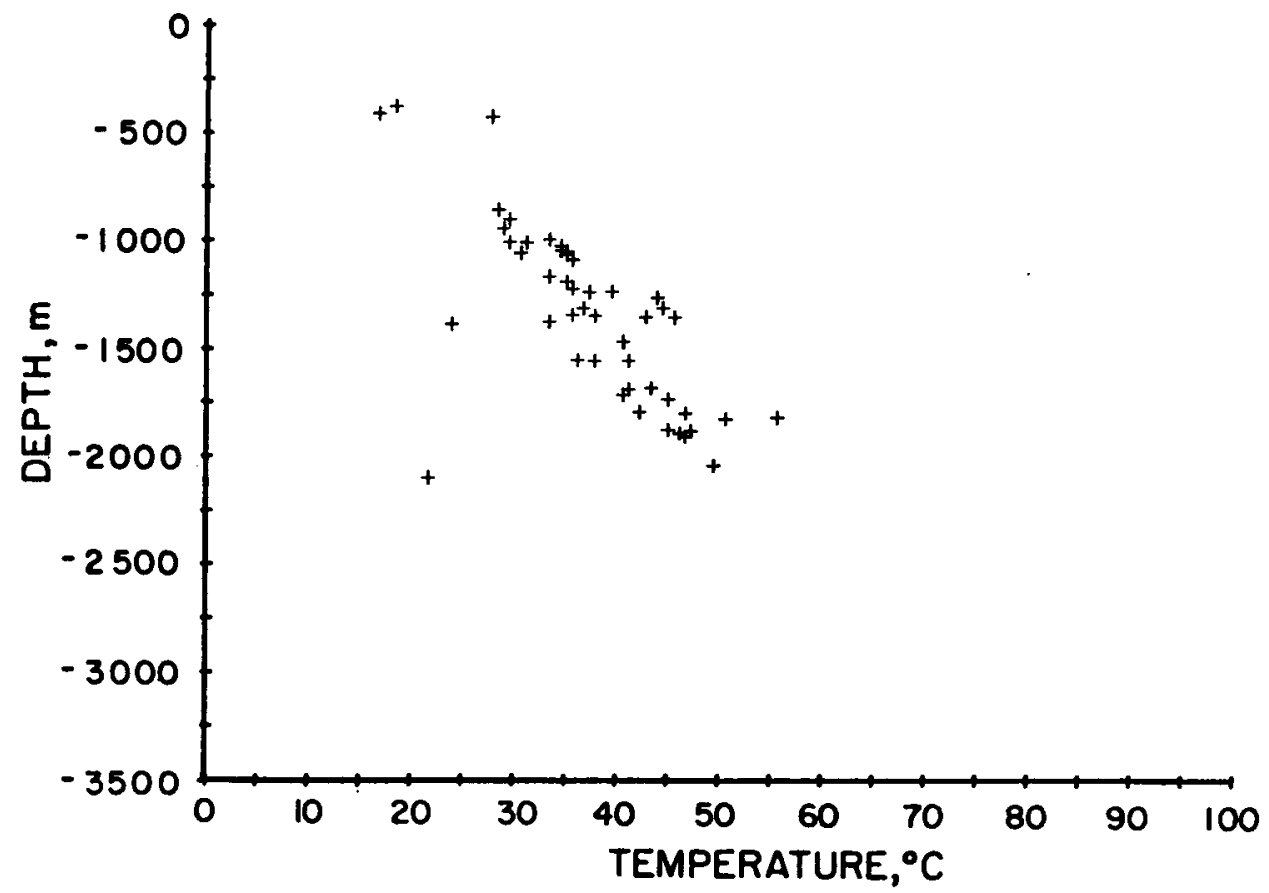

Fig. 14 .

BHT in wells in eastern Ohio.

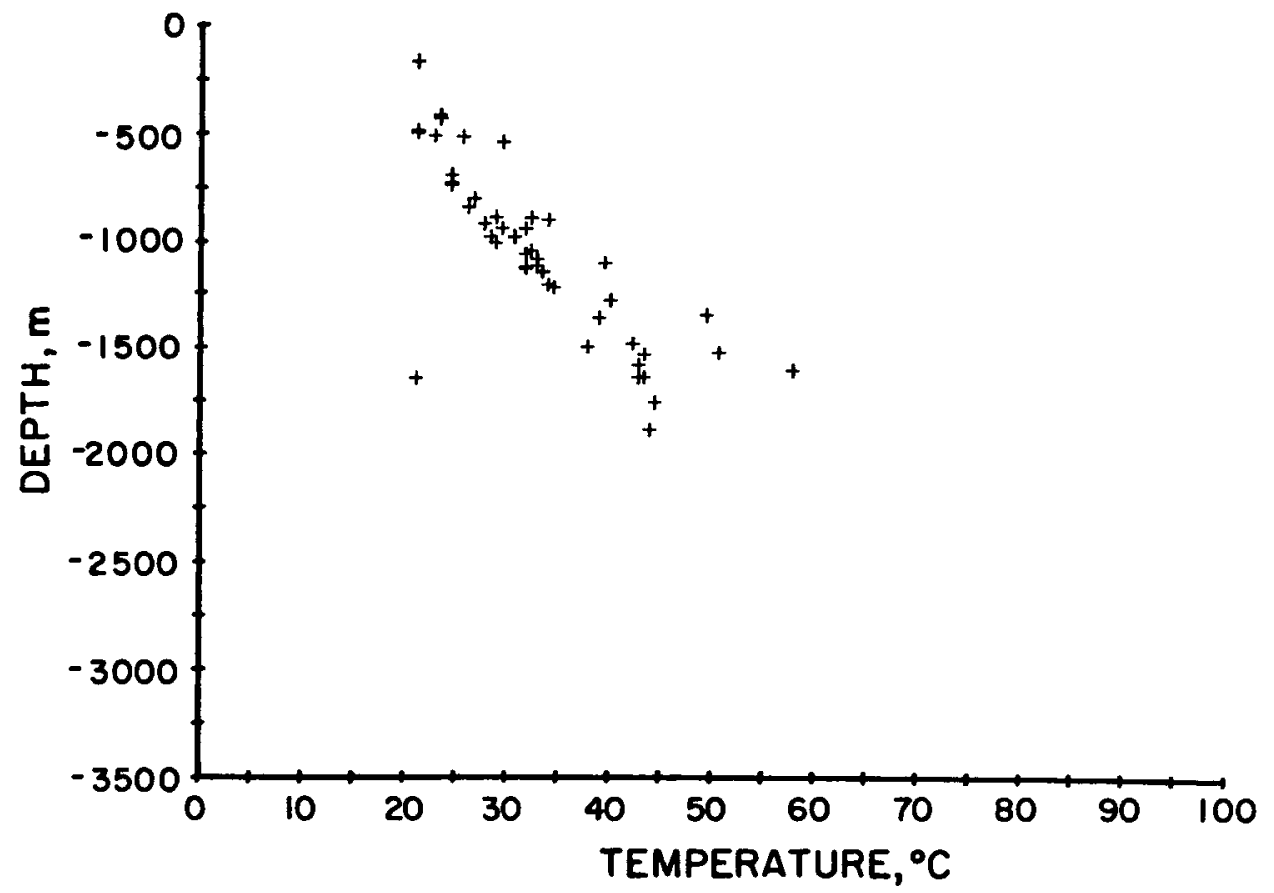

Fig. 15.

BHT in wells in southeastern Ohio. 


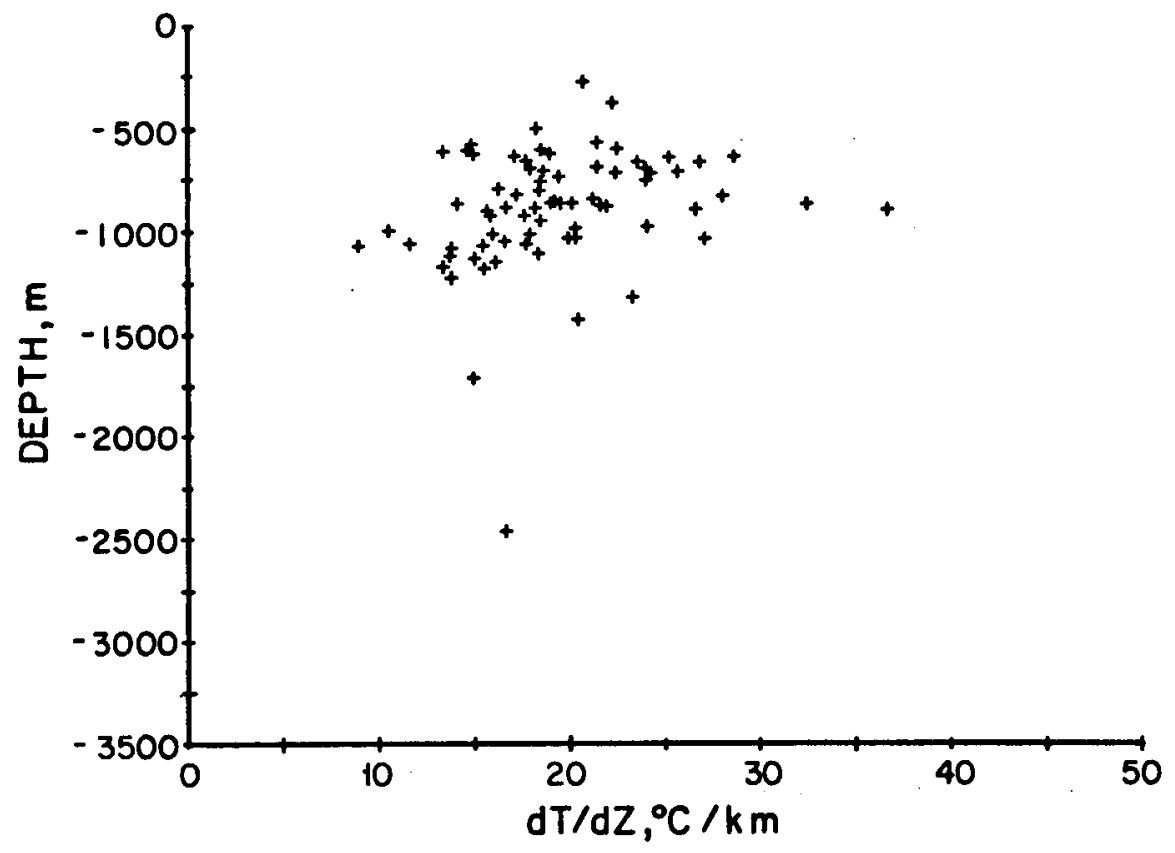

Fig. 16 .

Geothermal gradient as a function of depth in wells along the CincinnatiFindlay Arch in western Ohio.

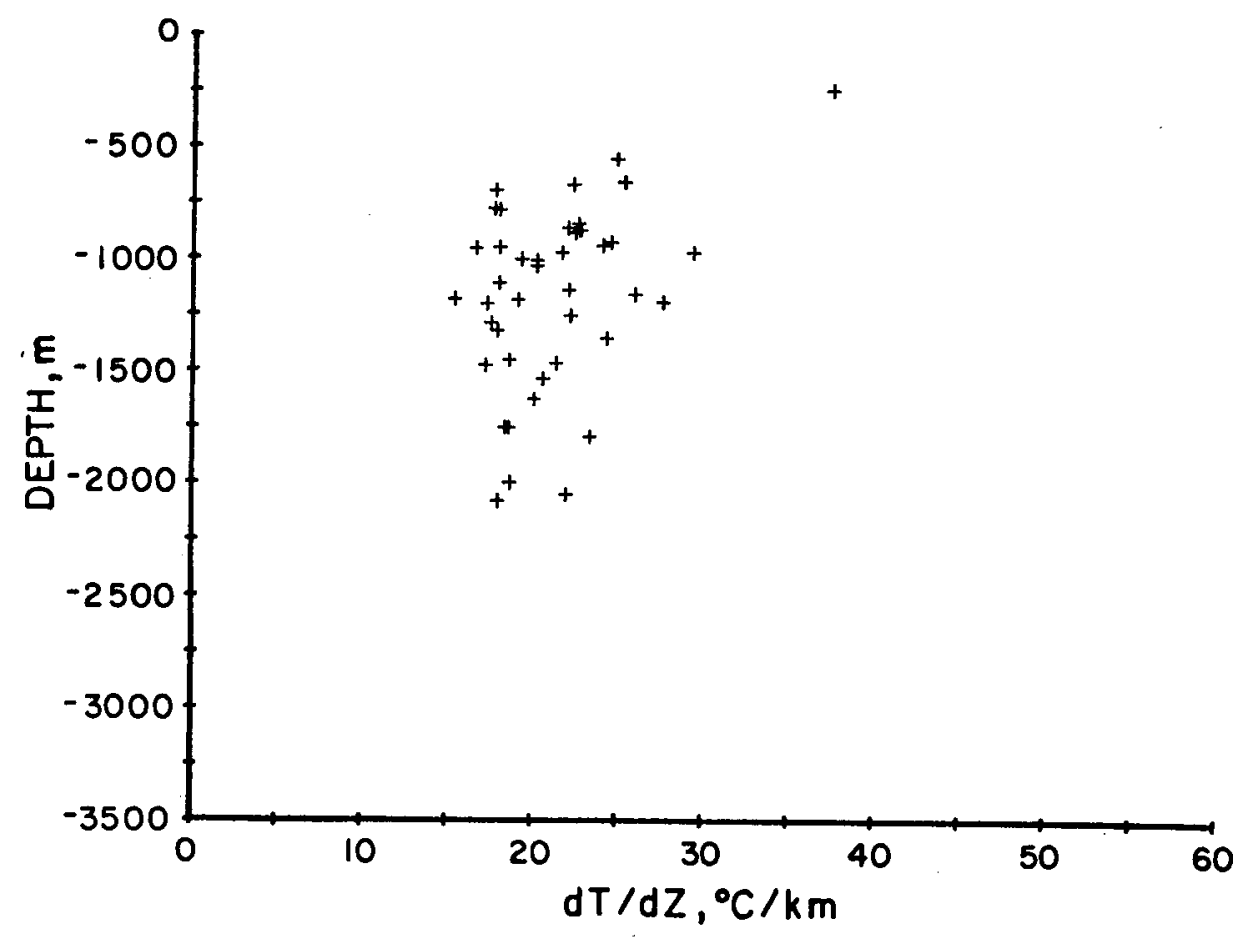

Fig. 17 .

Geothermal gradient as a function of depth in wells on the eastern flank of the Cincinnati-Findlay Arch in central ohio. 

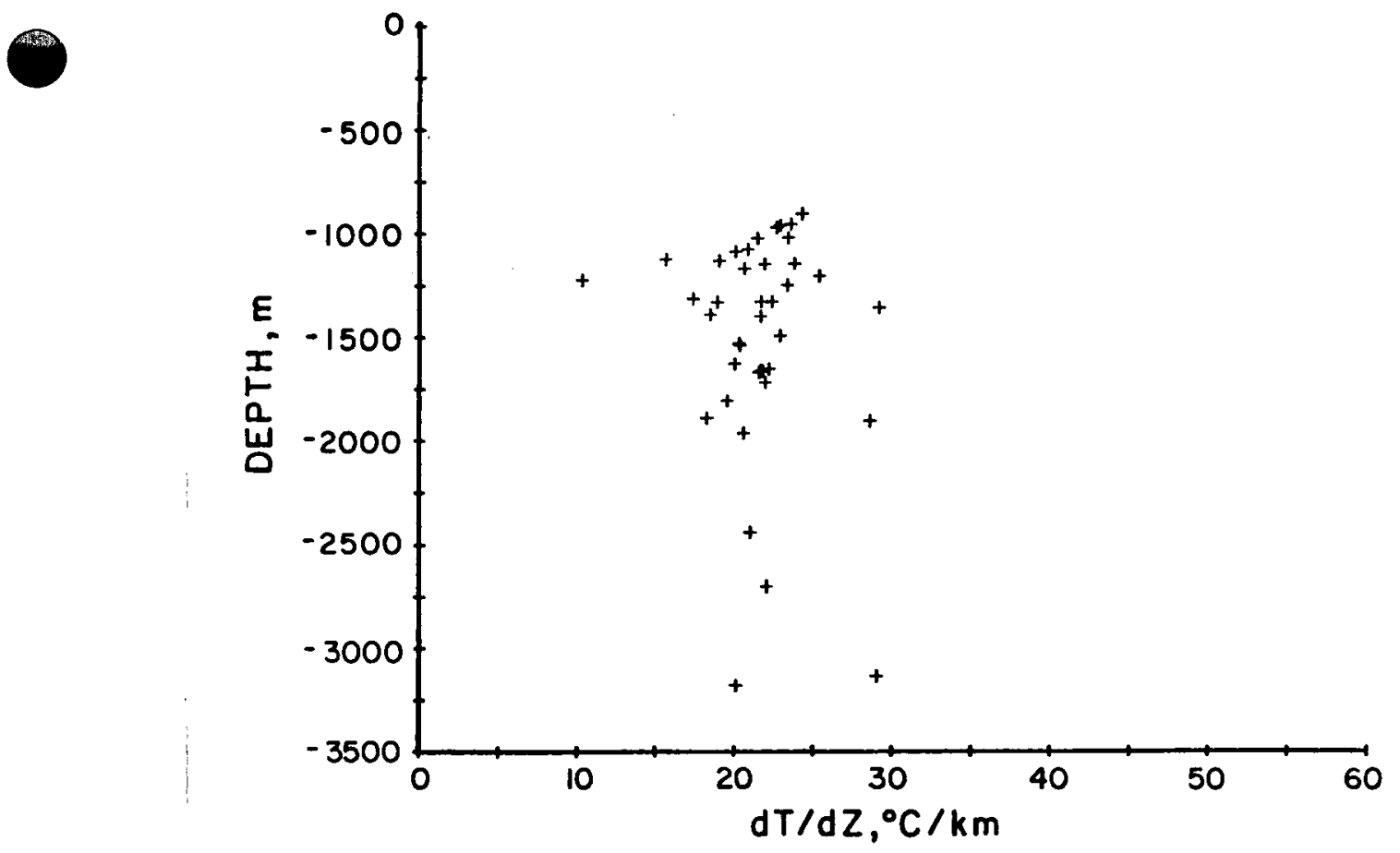

Fig. 18 .

Geothermal gradient as a function of depth in wells in northeastern Ohio.

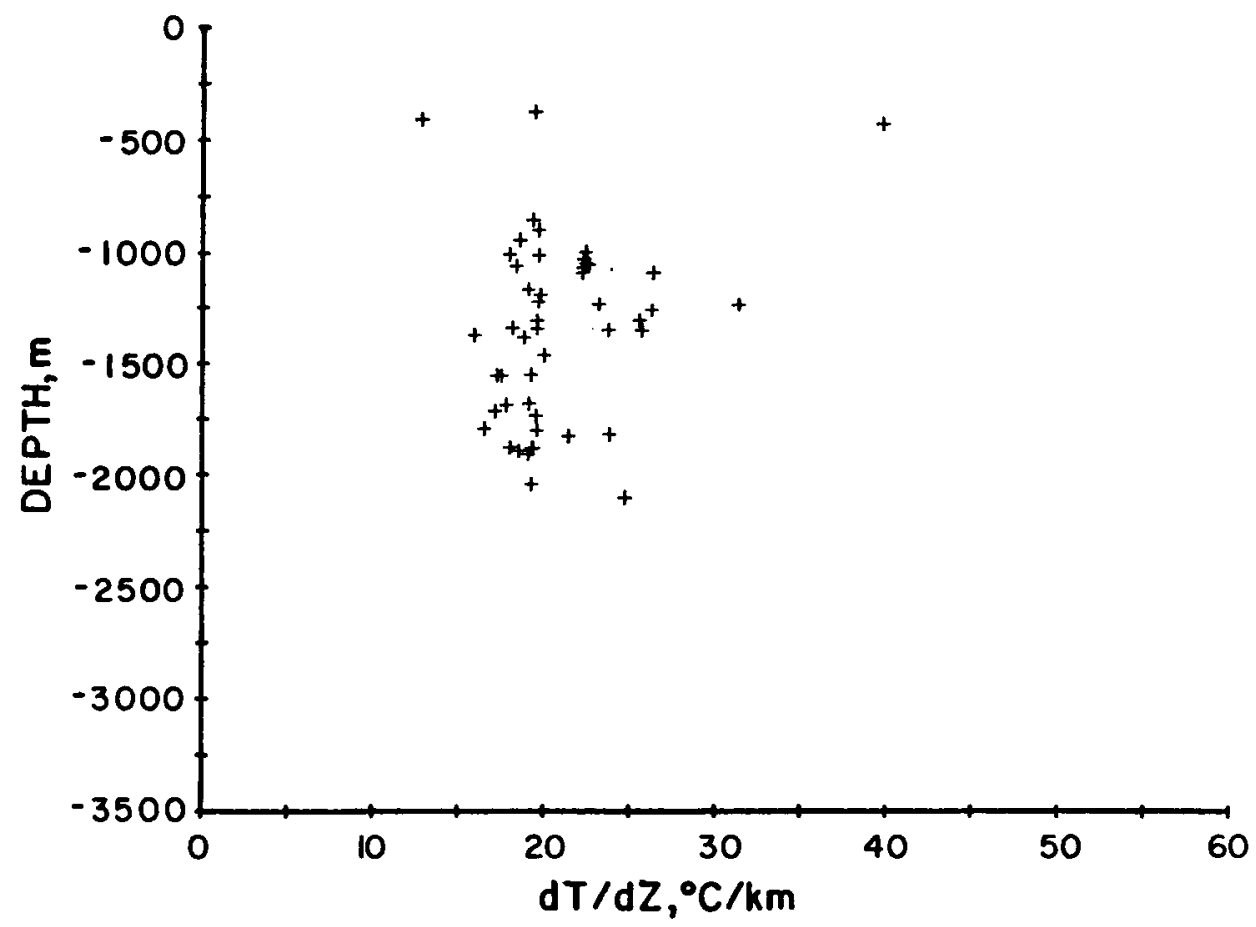

Fig. 19 .

Geothermal gradient as a function of depth in wells in eastern Ohio. 


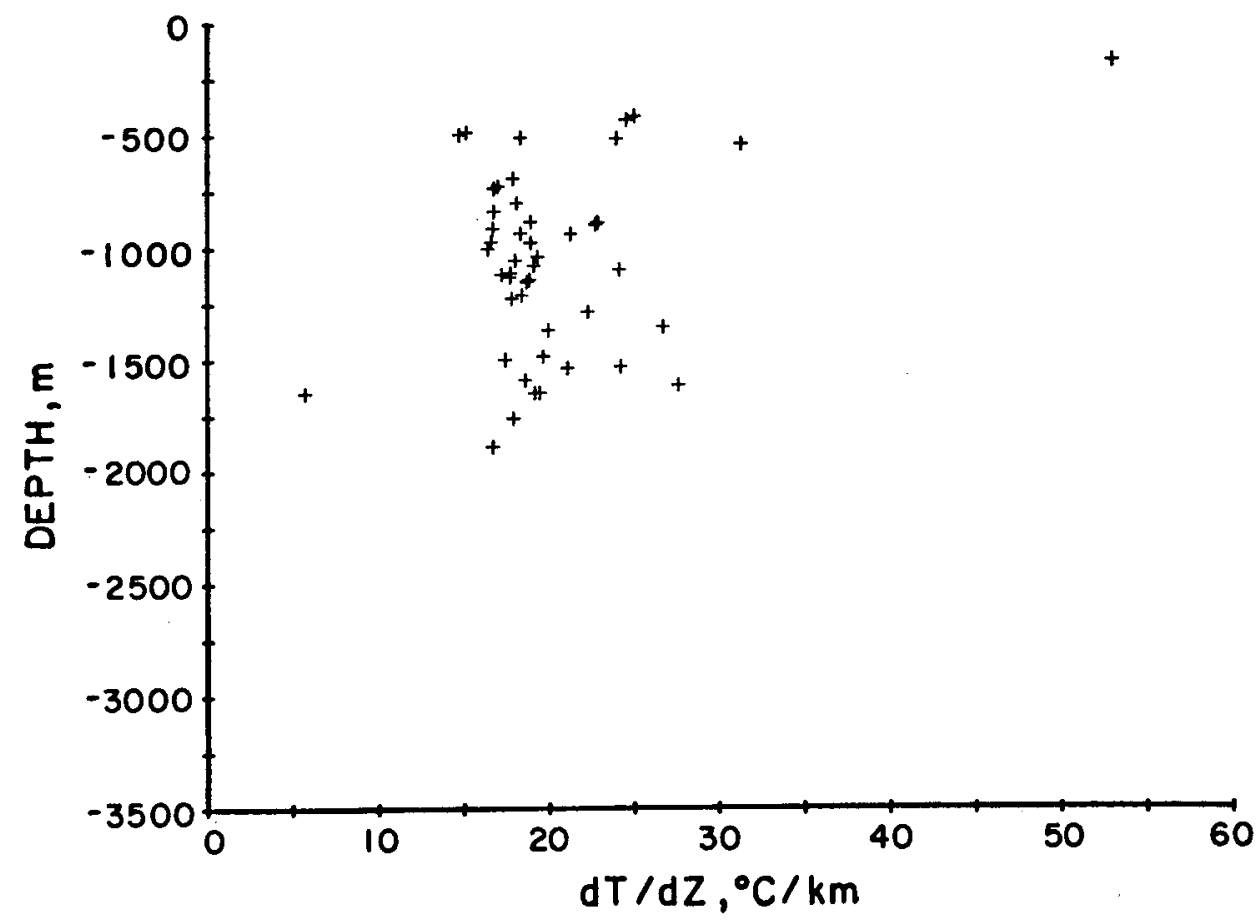

Fig. 20.

Geothermal gradient as a function of depth in wells in southeastern ohio.

Therefore, terrestrial heat within the sedimentary cover along the Cincinnati Arch may be transferred both by convection and by conduction; in contrast, the uniformity of the geothermal gradient east and west of the arch suggests predominantly conductive heat transfer. Accordingly, efforts to find deep holes for heat-flow measurements were concentrated in eastern ohio. One suitable well was measured in Washington County (Figs. 21, 22, and App. C), and another in Sumit County (Figs. 23, 24, and App. D).

\section{Pennsylvania}

The most prominent feature on the geothermal-gradient map of Pennsylvania (Fig. 7) is the northeast-trending anomaly centered on Venango County in the northwestern part of the state. The anomaly maximum exceeds $30^{\circ} \mathrm{C} / \mathrm{km}$, whereas the gradient for the remainder of Pennsylvania rarely exceeds $25^{\circ} \mathrm{C} / \mathrm{km}$ (Figs. 25-32). An exception is a weak high defined by the $30^{\circ} \mathrm{C} / \mathrm{km}$ contour at the common corners of Jefferson, Clearfield, and Elk Counties eastsoutheast of the Venango anomaly (Fig. 7). Gradient surveys were made in the Morrison well (Fig. 33) in Venango County and in the Bowser well (Fig. 34) in 

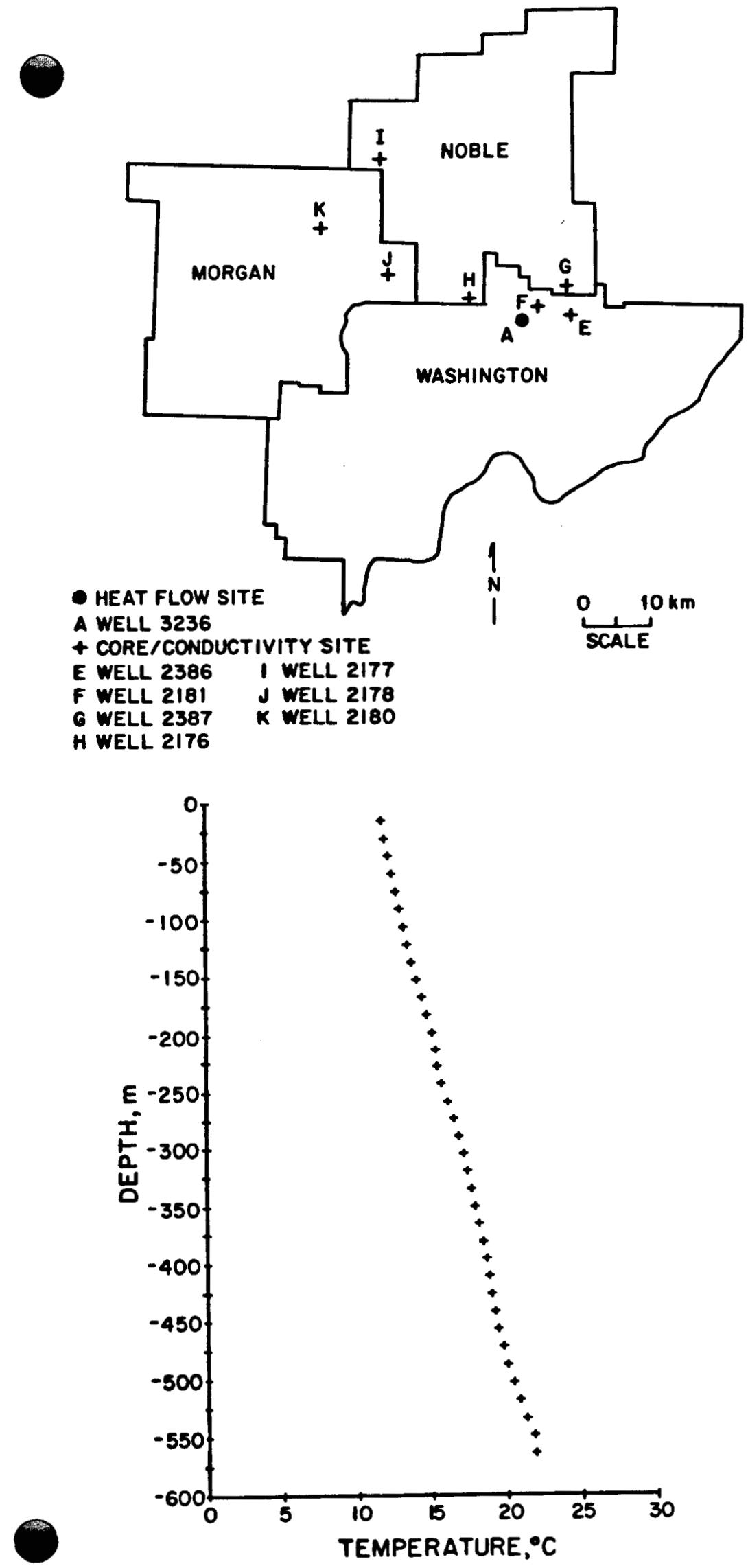

Fig. 21 .

Wells in Morgan, Noble, and Washington Counties, Ohio at which heat-flow measurements were made or core was collected for thermal conductivity determinations.
Fig. 22 .

Depth/temperature profile in We11 3236 in Washington County, Ohio. 


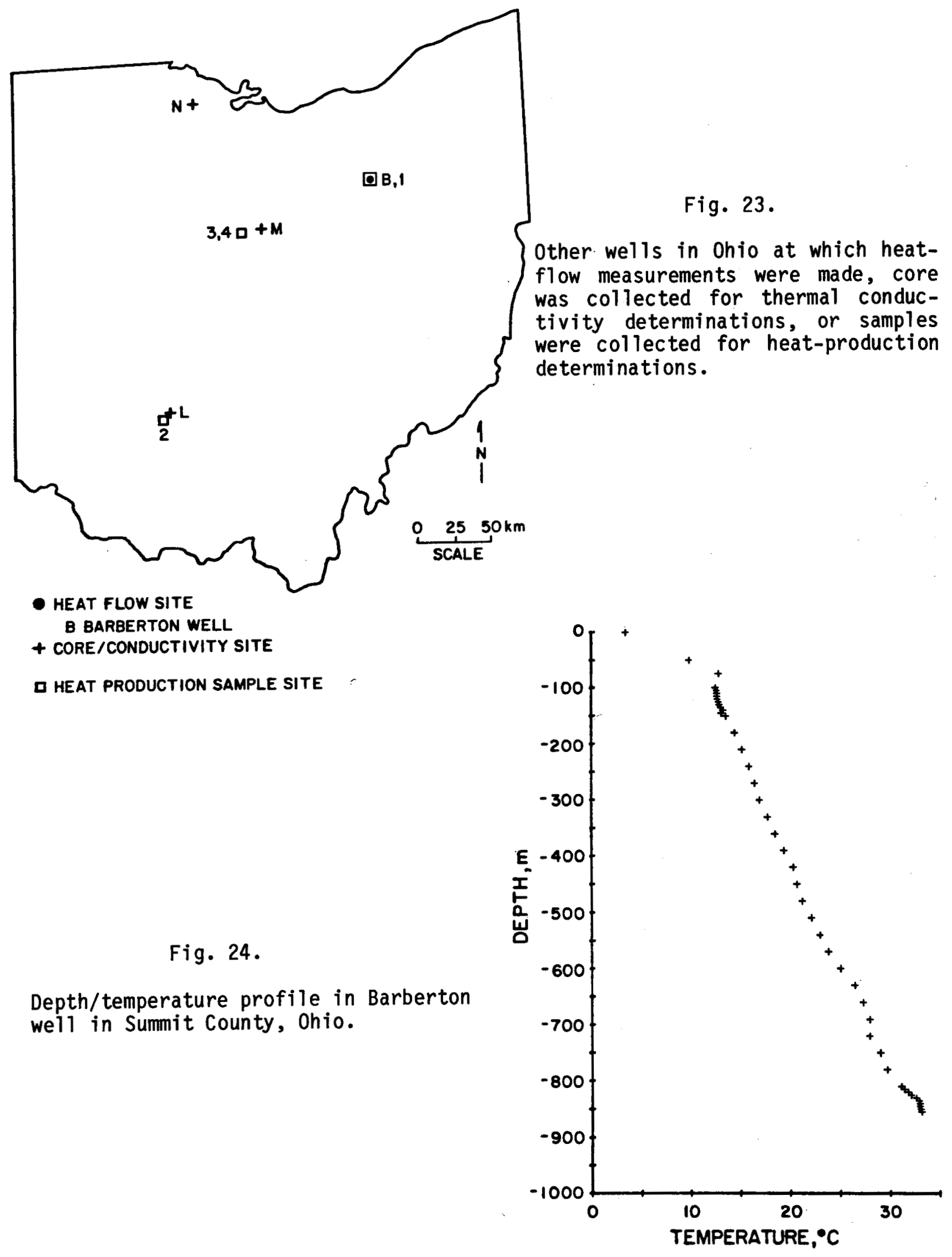




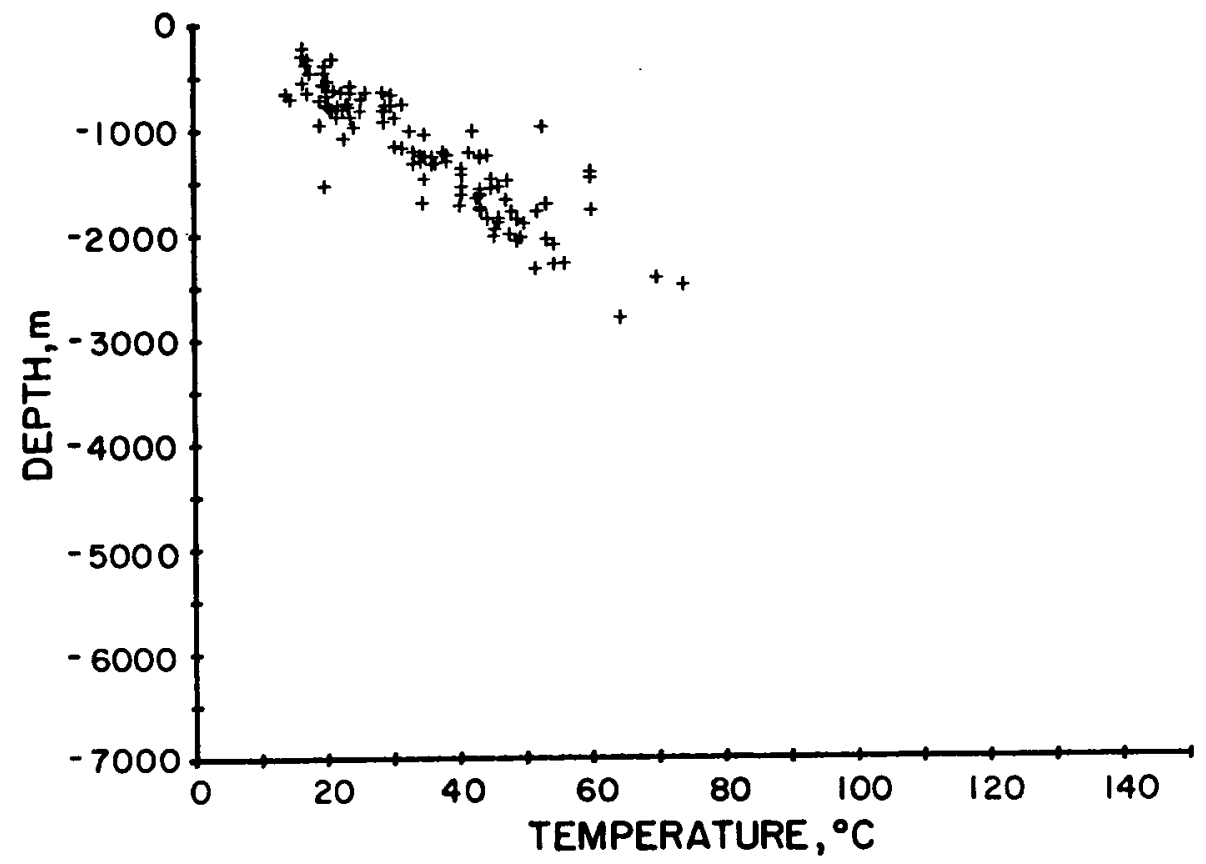

Fig. 25.

BHT in wells in northwestern Pennsylvania.

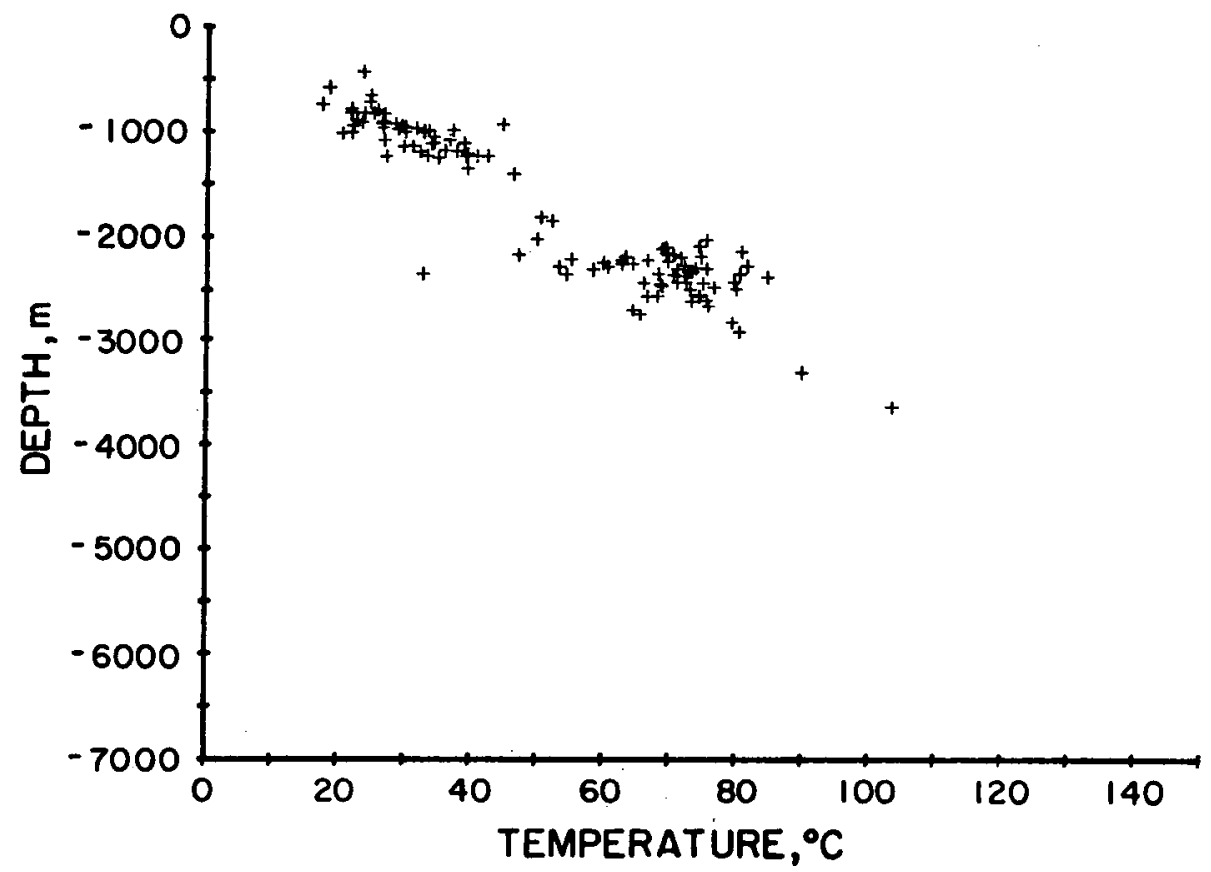

Fig. 26 .

BHT in wells in southwestern Pennsylvania. 


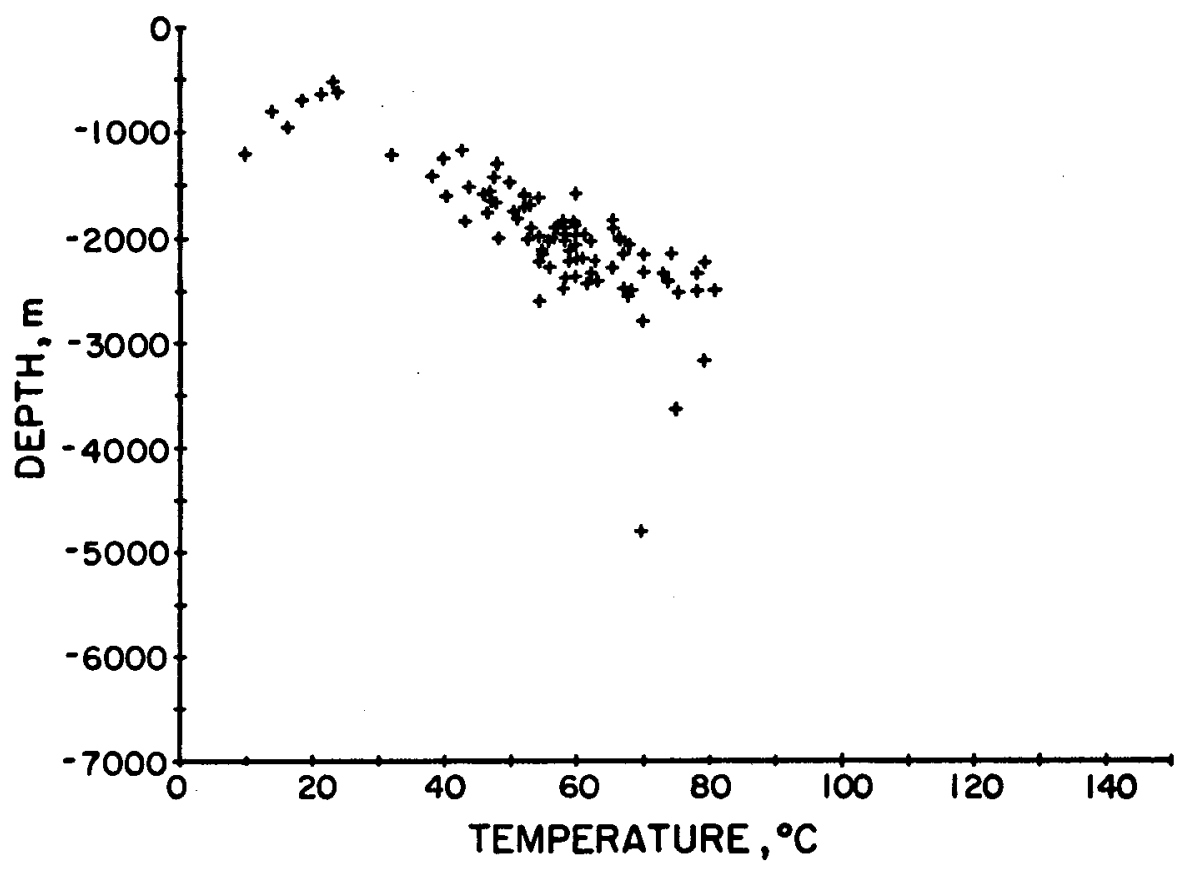

Fig. 27.

BHT in wells in north-central Pennsylvania.

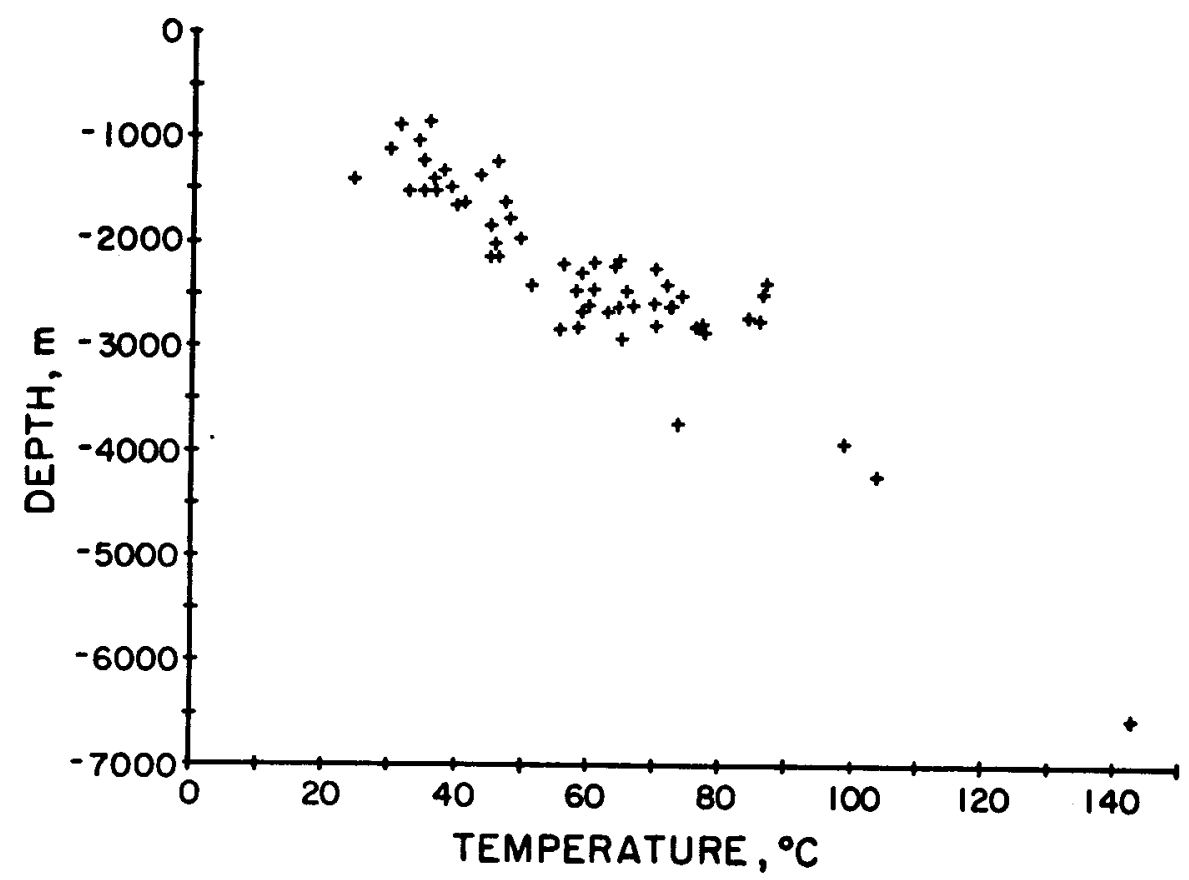

Fig. 28.

BHT in wells in central and northeastern Pennsylvania. 


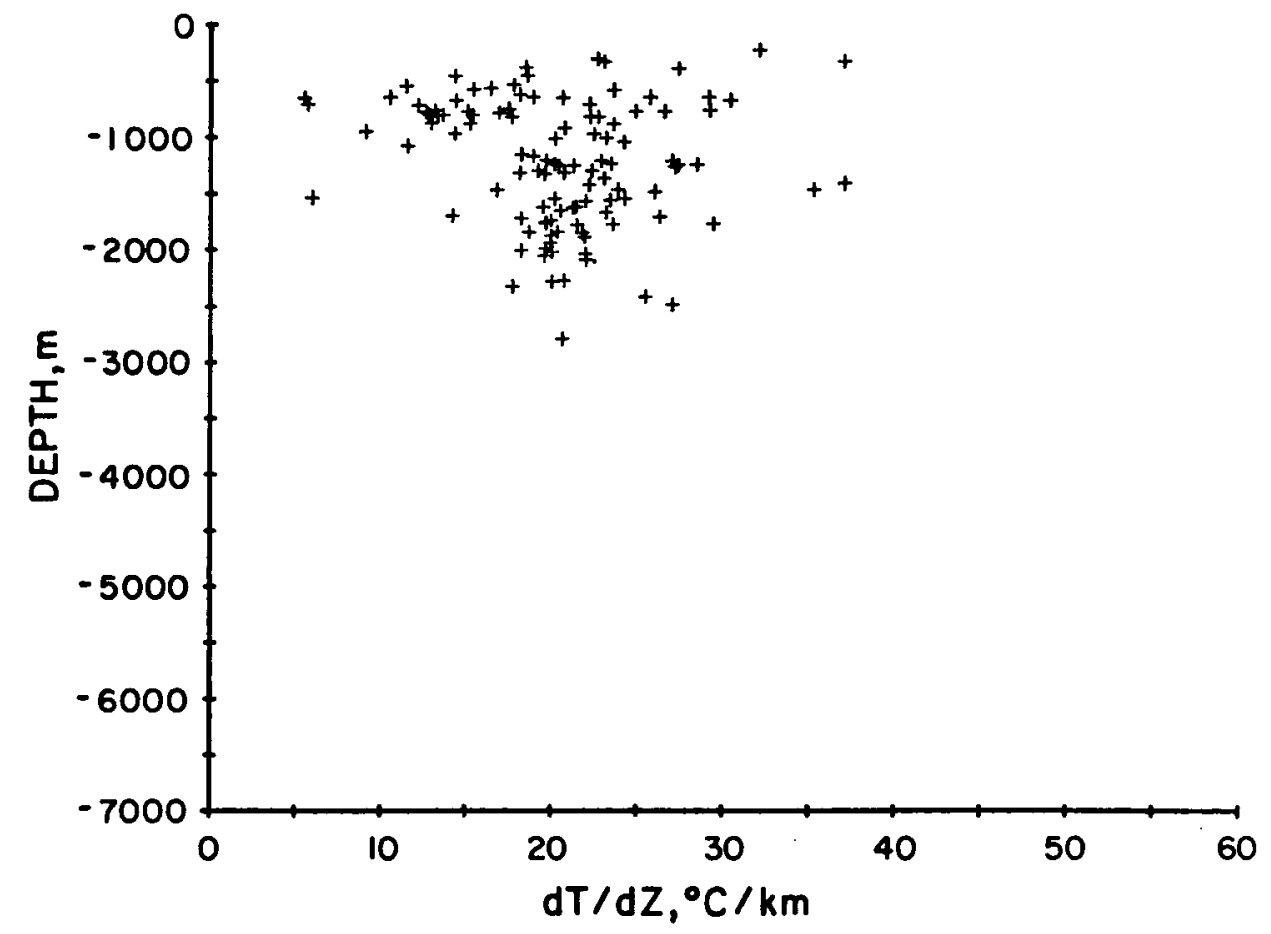

Fig. 29.

Geothermal gradient as a function of depth in wells in northwestern Pennsylvania.

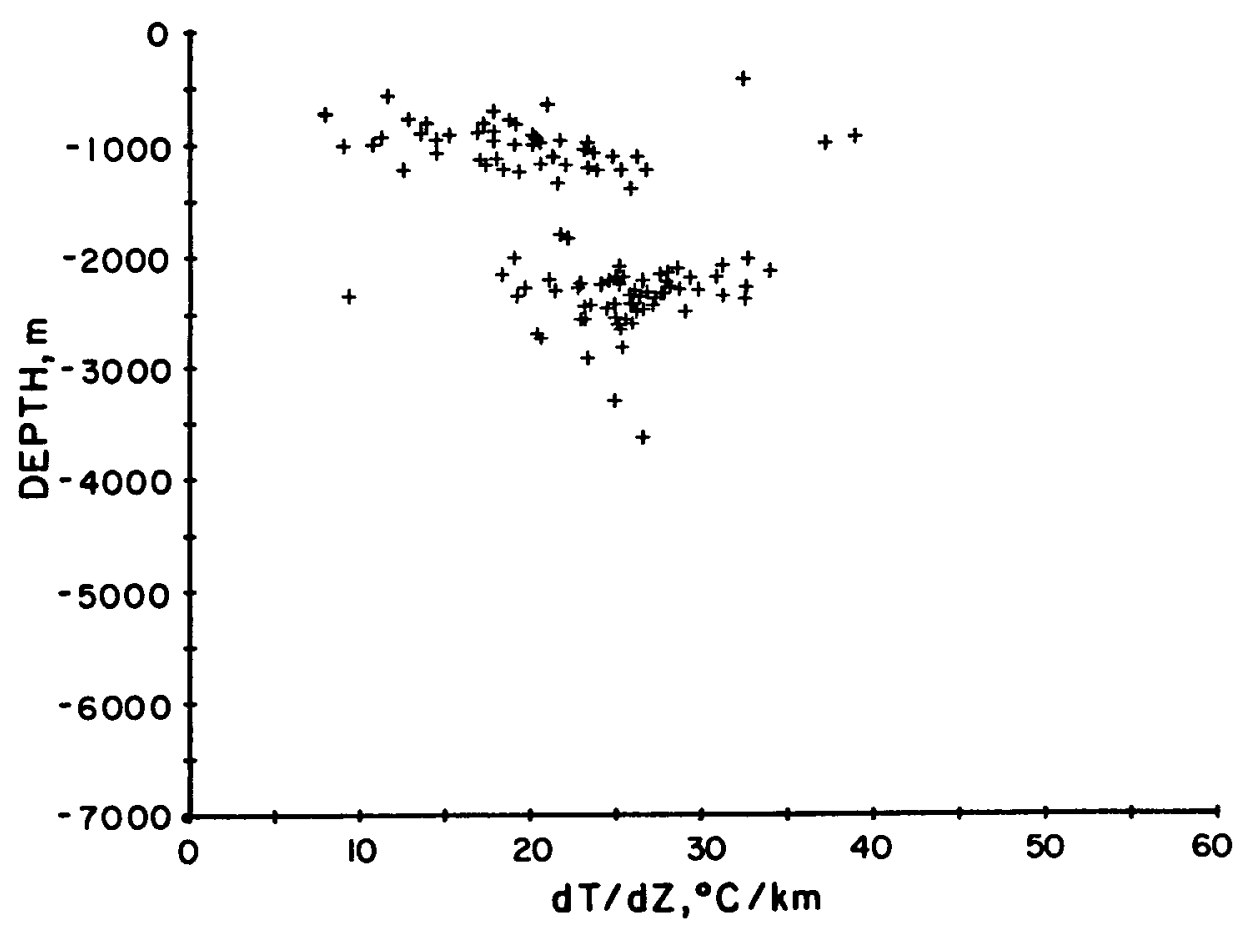

Fig. 30 .

Geothermal gradient as a function of depth in wells in southwestern Pennsylvania. 


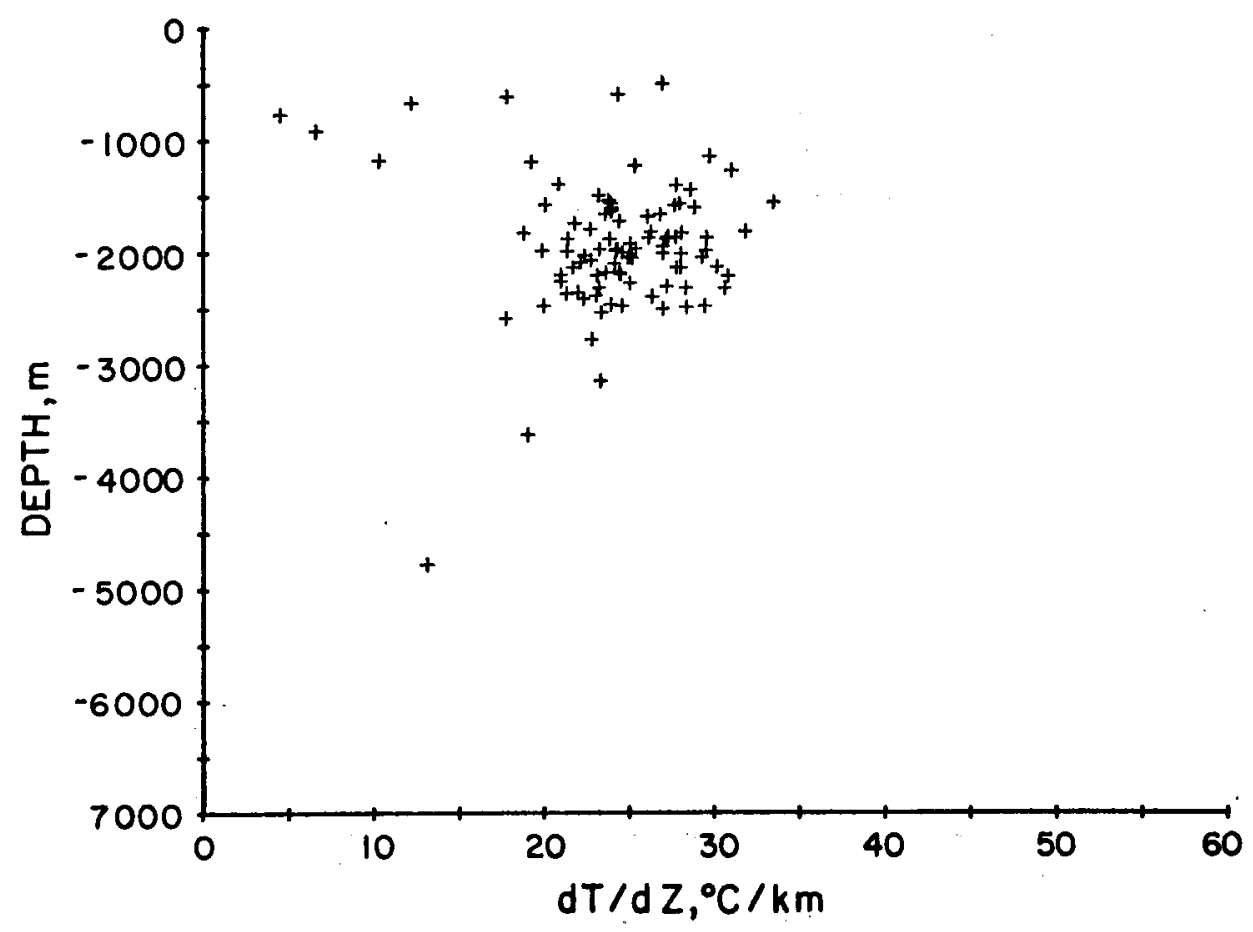

Fig. 31 .

Geothermal gradient as a function of depth in wells in north-central Pennsylvania.

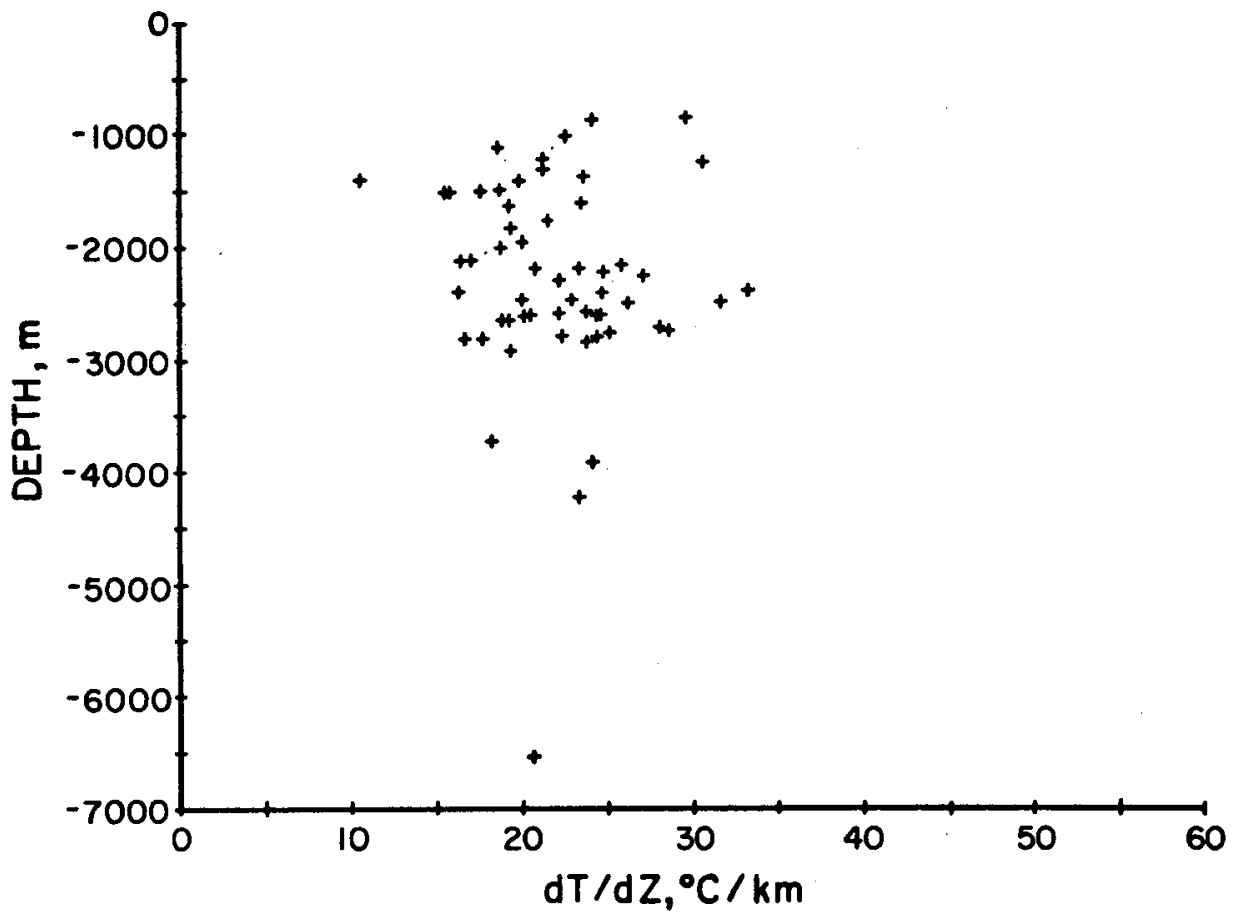

Fig. 32 .

Geothermal gradient as a function of depth in wells in central and northeastern Pennsylvania. 


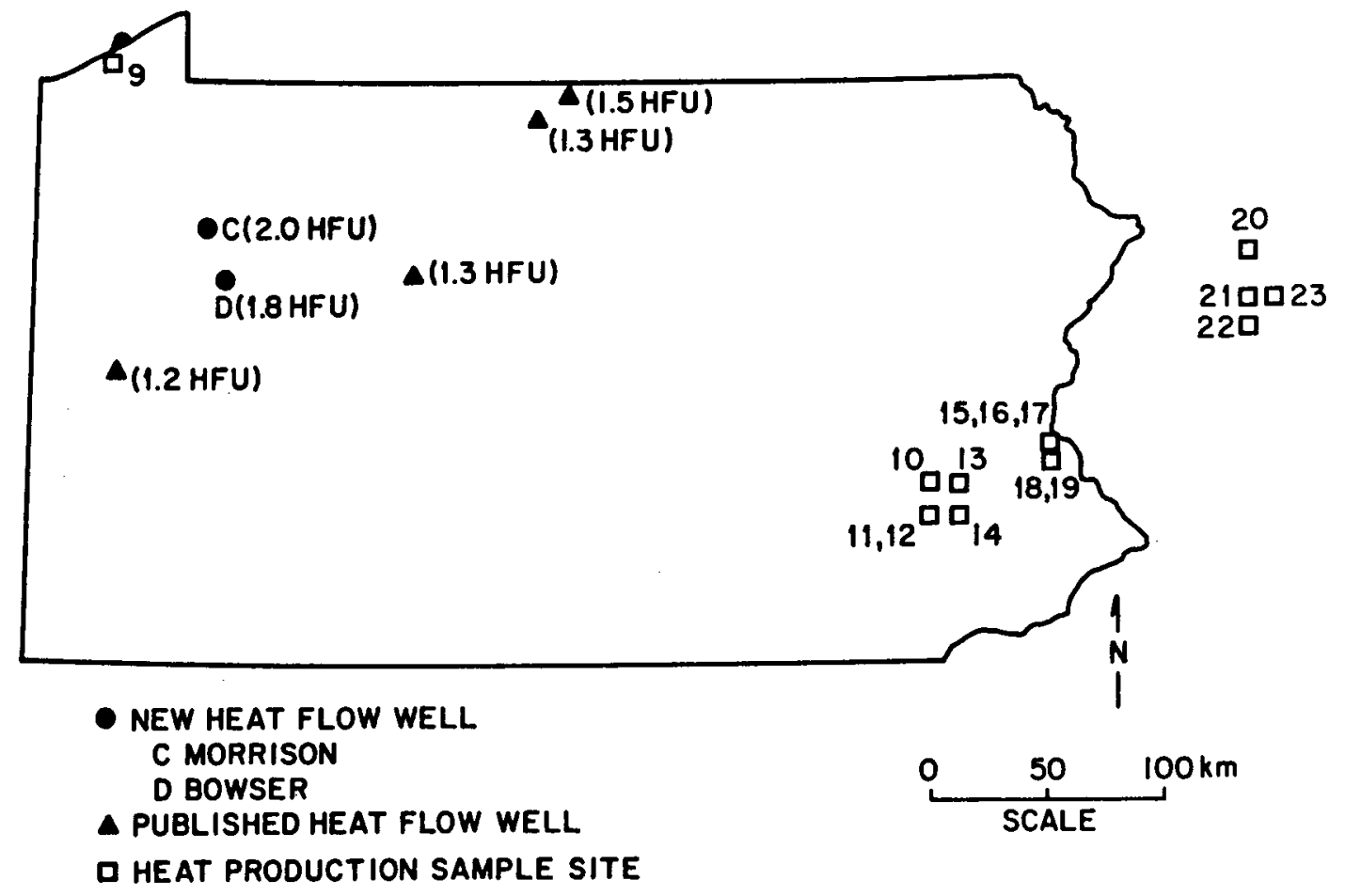

Fig. 33.

Wells and outcrops in Pennsylvania at which heat-flow measurements were made or samples were collected for heat-production determinations.

Clarion County. In addition, core samples from the Bowser well and samples from several wells near the Morrison well were used for measurement of thermal conductivities.

The Morrison well had been drilled to $323.1 \mathrm{~m}$ nine months before measurements were made. The Bowser well caved at $458 \mathrm{~m}$ in 1969 and is currently producing a small amount of gas from Mississippian sandstones in the uppermost $243 \mathrm{~m}$. Because of gas production, ground-water disturbances and, poor 1ithologic control, only measurements between depths of $243 \mathrm{~m}$ and $353 \mathrm{~m}$ were considered reliable. Depth/temperature profiles for the two wells are plotted in Figs. 35 and 36 . Basic temperature data and the relevant corrections are included in Apps. $E$ and $F$. Linear regression of the depth/temperature points within the useful intervals in the Morrison and Bowser wells yields mean uncorrected gradients of $22.63^{\circ} \mathrm{C} / \mathrm{km}$ and $22.53^{\circ} \mathrm{C} / \mathrm{km}$ respectively, and a correlation coefficient of 0.99 . Extrapolation of these gradients to a depth of $30.5 \mathrm{~m}$ gives values of $6.30^{\circ} \mathrm{C}$ and $7.36^{\circ} \mathrm{C}$. These values differ because of differences in the measured temperatures at depth. They are considerably 


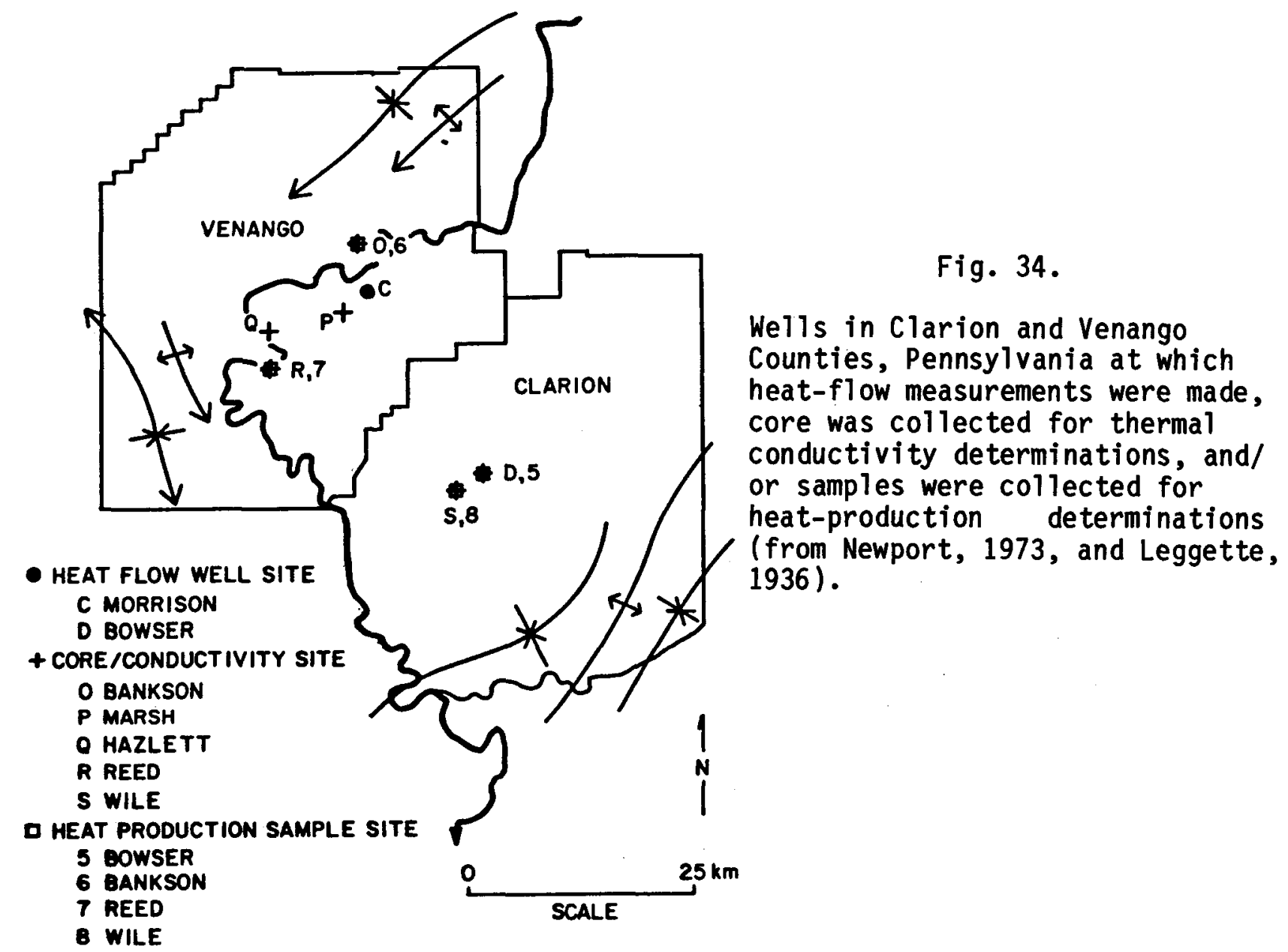

below the ground-water temperatures of $10.8^{\circ} \mathrm{C}$ and $11.0^{\circ} \mathrm{C}$, respectively. This discrepancy may be due mainly to ground-water heat transport, paleoclimatic effects, and effects of the Allegheny and Clarion Rivers, all of which tend to decrease the geothermal gradient at shallow depths, resulting in shallow temperatures (extrapolated from deeper horizons) lower than those measured. The correction for paleoclimatic effects (Birch, 1948; Urban, 1971; Diment et a1., 1972; Cermak, 1976) amounts to an increase to $6.96^{\circ} \mathrm{C} / \mathrm{km}$ and $3.07^{\circ} \mathrm{C} / \mathrm{km}$ in the geothermal gradients in the Morrison and Bowser wells.

Another belt having a relatively higher geothermal gradient, ranging from 25 to $30^{\circ} \mathrm{C} / \mathrm{km}$, extends from Elmira, New York, through the southwestern corner of Pennsylvania into West Virginia and southeastern Ohio. 


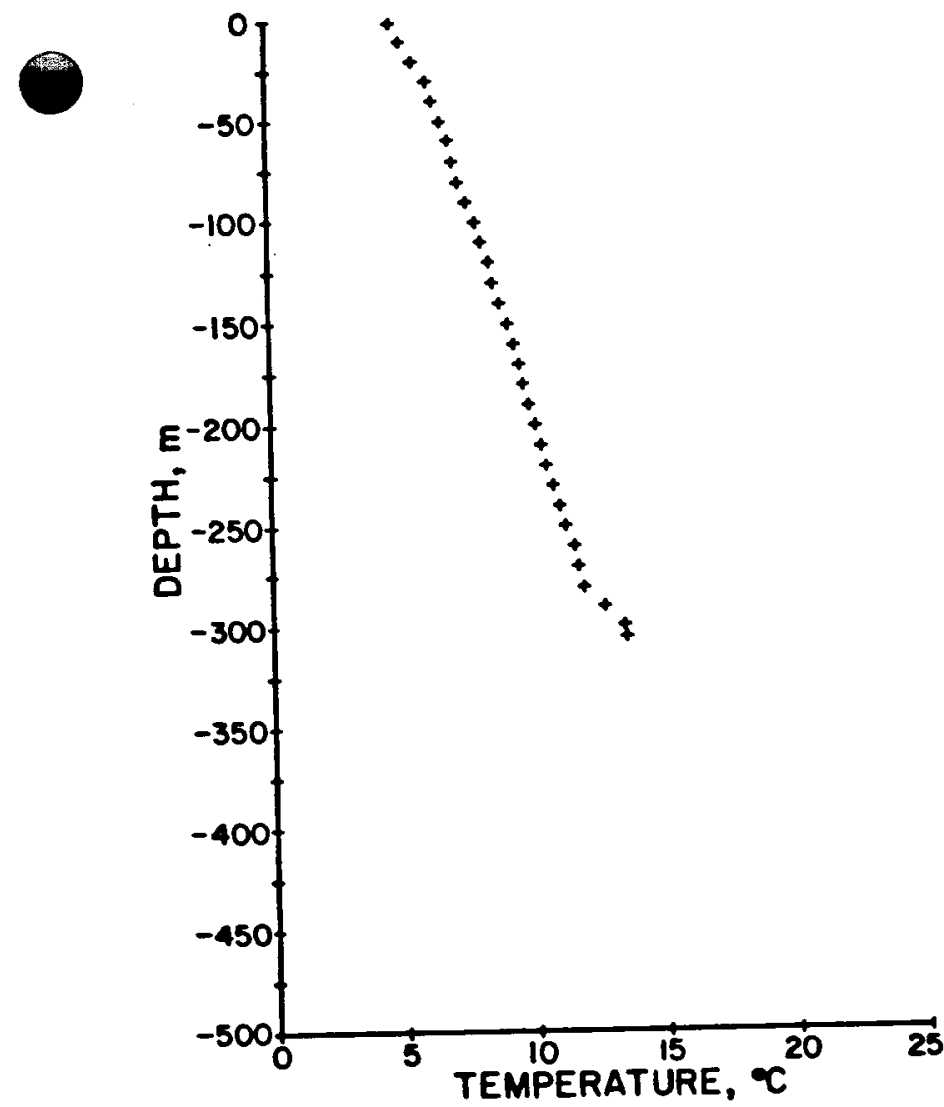

Fig. 35 .

Depth/temperature profile in Morrison well in Venango County, Pennsylvania.

Fig. 36 .

Depth/temperature profile in Bowser well in Clarion County, Pennsylvania.

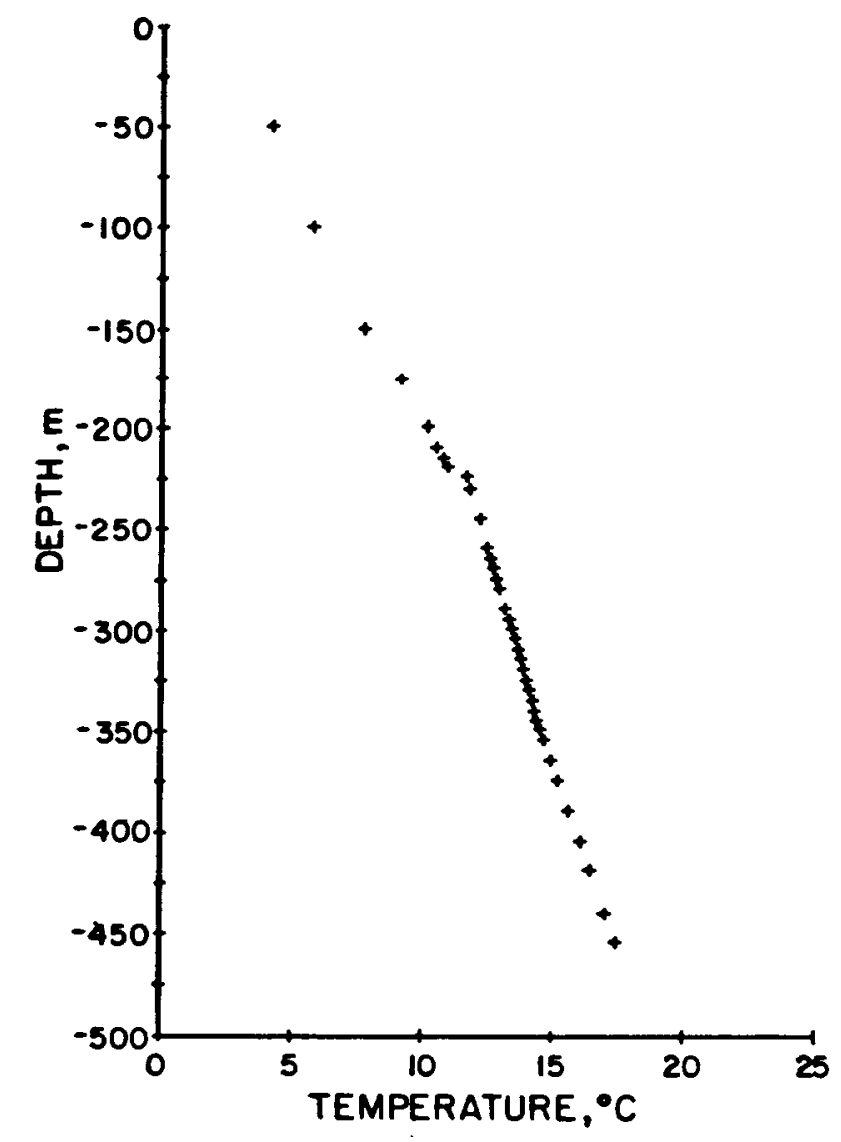


Thermal Conductivity

In practice terrestrial heat flow, $q$ is approximated by

$$
q=\bar{K}(\Delta T / \Delta z),
$$

where $\Delta T$ is the temperature difference over a finite depth interval $\Delta z$ comprised of material having a mean thermal conductivity of $K$.

Thermal conductivity of the rock formations was determined by measurements on core samples using the divided-bar technique (Birch, 1950). The measurements were obtained on machined core-discs, 1.27 to $3.18 \mathrm{~cm}$ thick, under an axial pressure of 50 bars that reduced contact resistance to negligible values. Temperatures across the divided bar were measured with thermistors calibrated to $\pm 0.02^{\circ} \mathrm{C}$ with a platinum resistance thermometer. Each core sample was measured for thermal conductivity first "off-the-shelf" and second after saturation with water in a vacuum chamber.

A total of 77 core samples were obtained from wells in Washington, Noble, and Morgan counties in southeastern Ohio (App. G), 29 core samples were taken from the Barberton well (App. H), and 37 other core samples were obtained from wells in southern, central, and northern ohio (App. I). A total of 64 core samples were taken from wells in Venango and Clarion counties in Pennsylvania (App. J).

Computations of the terrestrial heat flow were done using the interval method. Each well was divided into a series of uniform depth intervals $(\Delta z)$. The temperature difference $(\Delta T)$ for each interval was measured and the mean thermal conductivity $(K)$ was computed. The measured thermal conductivities of representative core samples of each rock unit penetrated were averaged to determine the mean thermal conductivity for each rock type. These means were averaged by weighting the percentage of each lithologic type comprising each depth interval $(\Delta z)$ in wells from which no core samples were available. The mean heat flow of the evaluated intervals is considered to be the best approximation for the observed terrestrial heat flow. The calculated heat-flow values, with appropriate corrections for each site, are given in Table II.

Three basement samples from 0 hio and five from Pennsylvania were analyzed for U(ordinary), ${ }^{232} \mathrm{Th}$, and $\mathrm{K}_{2} \mathrm{O}$ by the Los Alamos National Laboratory. Five samples of shale from Ohio and 11 samples from Pennsylvania also were analyzed at the Los Alamos National Laboratory for U(ordinary) ${ }^{232} \mathrm{Th}$ and $\mathrm{K}$. Analysis of U(ordinary), ${ }^{232} \mathrm{Th}$, and $\mathrm{Ra}$ contents in 34 
TABLE II

HEAT-FLOW VALUES

\begin{tabular}{|c|c|c|c|c|c|}
\hline \multirow[b]{2}{*}{ Well Name } & \multicolumn{2}{|c|}{ Site Location } & \multirow{2}{*}{$\begin{array}{c}Q^{a} \\
\left(\mu \mathrm{cal} / \mathrm{cm}^{2} \mathrm{sec}\right)\end{array}$} & \multirow{2}{*}{$\begin{array}{c}Q^{b} \\
\left(\mu \mathrm{cal} / \mathrm{cm}^{2} \mathrm{sec}\right)\end{array}$} & \multirow{2}{*}{$\begin{array}{c}Q^{d} \\
\left.(\mu \mathrm{ca}) / \mathrm{cm}^{2} \mathrm{sec}\right)\end{array}$} \\
\hline & Site & $\frac{\operatorname{con}}{W}$ & & & \\
\hline 3236 & $39^{\circ} 33^{\prime} 30^{\prime \prime}$ & $81^{\circ} 26^{\prime} 25^{\prime \prime}$ & $1.14 \pm 0.23$ & $1.33 \pm 0.23$ & $1.36 \pm 0.25$ \\
\hline Barberton & $41^{\circ} 01^{\prime} 15^{\prime \prime}$ & $81^{\circ} 37^{\prime} 30^{\prime \prime}$ & $1.14+0.20$ & $1.37 \pm 0.21$ & $1.37 \pm 0.20$ \\
\hline Morrison & $41^{\circ} 23^{\prime} 52^{\prime \prime}$ & $79^{\circ} 43^{\prime} 25^{\prime \prime}$ & $1.44 \pm 0.55$ & $1.92 \pm 0.75^{c}$ & $2.00 \pm 0.72$ \\
\hline Bowser & $41^{\circ} 14^{\prime} 00^{\prime \prime}$ & $79^{\circ} 31^{\prime} 52^{\prime \prime}$ & $1.73 \pm 0.41$ & $1.97 \pm 0.47$ & $1.84 \pm 0.36$ \\
\hline
\end{tabular}

surface samples of basement rock from the Reading Prong in eastern Pennsylvania and New Jersey were made by A. Drake of the U.S. Geological Survey. Radium content was used because $K_{2} O$ analyses were not available. The analyses and corresponding heat-production rates are shown in App. $K$.

\section{DISCUSSION AND CONCLUSIONS}

The low-enthalpy convective system associated with the axis of the Cincinnati-Findlay Arch was postulated (Cannon et al., 1980) based on the inverse correlation between the low geothermal gradient and relatively higher ground-water temperatures in the shallow aquifers along the crest of the arch. Cannon et al., (1980) also observed that the warmer ground water in the shallow aquifers contains relatively high concentrations of chloride, total dissolved solids, and silica. The high ionic concentrations in the warmer, shallow ground water may be evidence for the convective model because they result from influx of brackish or saline connate water from deep bed-rock formations into the shallow aquifer through faults and fractures. The distribution of the BHT and of the calculated geothermal gradients (Figs. 10-30) provides additional support for the proposed model (Cannon et al., 1980). Moreover, from Fig. 10 it may be inferred that groundwater at a temperature as high as $60^{\circ} \mathrm{C}$ may be found along the Cincinnati-Findlay Arch at depths not exceeding $600 \mathrm{~m}$. 
The uncorrected heat flow in Clarion County, Pennsylvania is higher than average for the eastern United States (Diment et al., 1972; Sass et al., 1976). When corrected for environmental conditions, the heat flows in Clarion and Venango counties are markedly higher than the mean of 1.34 heat-flow units (HFU) for the eastern United States (Urban, 1971). The values define a local heat-flow high not associated with other reported heat-flow highs in New York (Urban, 1971; Hodge, D. S., 1979, personal communication) nor in other northeastern states (Sass et al., 1980).

The pronounced northeast-trending trough (Fig. 9) on the ground-water temperature map of Pennsylvania and the decreasing hydraulic gradient in northwestern Pennsylvania may result from cold recharge along the Allegheny Mountains and the Allegheny drainage basin, respectively. If so, the geothermal-gradient highs (Fig. 7) mark areas of higher than average conductive heat flow. The area of elevated ground-water temperature (Fig. 9) in southwestern Pennsylvania corresponds roughly with above-average geothermal gradients (Fig. 6).

The Bouguer gravity map of Pennsylvania indicates a southwest-trending gravity low centered at Pittsburgh (Fig. 4). The wavelength of southwesttrending aeromagnetic high centered in Venango county (U. S. Geological Survey, 1979) may indicate that the source of the anomaly is within the upper crust.

Birch et al., (1968), Roy et al., (1968), and Lachenbruch (1968, 1970) observed a linear relation between heat flow $(Q)$ and radiogenic heat production $(A)$ :

$$
Q=a+b A,
$$

where $a$ is the portion of the observed heat flow originating from the lower crust and mantle. The coefficient corresponding to the thickness of the heat-producing layer of the upper crust is $b$. The values of $a$ and $b$ are 0.69 and 6.9 respectively for the eastern heat-flow province, according to costain et al., (1980). For the topographically. corrected heat flows of Venango and Clarion counties, the relation would indicate upper crustal heat productions of 11.59 heat-generation units (HGU) and 13.48 HGU respectively, which are much higher values than heat production from the Precambrian basement determined in nearby Erie County (App. K). 
Based on a two-layer model, that crustal thickness is approximately 36-45 km (Pakiser and Steinhart, 1964). Assuming a mantle heat flow of 0.4 HFU (Roy et al., 1968) and a lower crustal contribution of 0.95 HFU (Urban, 1971), the upper crustal contribution would be $1.05 \mathrm{HFU}$ for Venango County and $0.89 \mathrm{HFU}$ for Clarion County. This is approximately three times the typical upper crustal contribution for the eastern heat-flow province. Perhaps some excess heat flow is due to the highly radiogenic Pennsylvanian and Mississippian shales (App. $K$ ), but the heat production of the shales beneath the Venango anomaly differs little from that of samples below non-anomalous areas in Ohio. Moreover, the Venango anomaly does not coincide with the center of the Appalachian Basin, where the sedimentary cover is thickest (Fig. 1 ). Therefore, the anomaly may be associated with abnormally high heat production in the upper crust. A more detailed gravimetric survey might provide more information on the nature of the anomaly. If the anomaly is associated with a younger, felsic intrusion, characterized by a high concentration of radiogenic elements, such a survey would help delimit the spatial distribution of the anomaly.

The heat-flow values found elsewhere are well within the commonly expected values characteristic of the Allegheny Plateau, (1.22 to $1.89 \mathrm{HFU})$ (Joyner, 1960).

\section{SUMMARY AND RECOMMENDATIONS}

Two types of geothermal anomalies were encountered during the course of the project. The anomaly in western Ohio is of a convective character, 1 imited to moderate depths within the sedimentary cover. Ground water, at temperatures that may be useful in local agricultural and space-heating projects, seems to convect from deeper formations to shallow zones through the system of faults and fractures associated with the Cincinnati-Findlay Arch. Further research efforts emphasize detailed mapping of the fault and fracture system along the arch and fuller characterization of the hydrothermal phenomena associated with the system. Side-looking airborne radar combined with infrared photography would be useful in mapping the faults and fractures associated with the arch. Ground water should be sampled and analyzed from all available wells.

The heat-flow anomaly in northwestern Pennsylvania seems to be associated with an anomalous heat source within the upper crust. The source 
probably is within the Precambrian basement, and may be a felsic intrusion having a relatively high concentration of radioactive elements. To determine the validity of this interpretation, a detailed gravimetric survey of the anomalous region and additional heat-flow measurements are recommended. The latter should be determined on at least five cores from wells 500-1000 m deep. Additional heat-flow measurements are recommended in other areas of Pennsylvania where geothermal gradients exceed $30^{\circ} \mathrm{C} / \mathrm{km}$ (Fig. 6 ).

\section{ACKNOWLEDGMENTS}

The assistance of M. W. Schlorholtz, G. G. Maurath, M. F. Schmidt, and M. S. Cannon while graduate students at Kent State University is gratefully acknowledged.

\section{REFERENCES}

American Association of Petroleum Geologists and U.S. Geological Survey, 1976, Subsurface temperature map of North America.

Barbis, F. C., 1978, Rb-Sr geochronology of the Precambrian basement of Ohio, Ohio State Univ. unpub. M.S. thesis, 83 p.

Bass, M. N., 1960, Grenville boundary in Ohio, J. Geol., v. 68, p. 673-677.

Birch, F., 1948, The effects of Pleistocene climatic variations upon geothermal gradients, Am. J. Sci., v. 246, p. 729-760.

Birch, F., 1950, Flow of heat in the Front Range, Colorado, Geol. Soc. Am. Buti., v. 61, p. 567-630.

Birch, F., Roy, R. F., and Decker, E. R., 1968, Heat flow and thermal history in New England and New York, in Zen E., White, W. S., Hadley, J. B., and Thompson, J. B., Jr., ed., Studies of Appalachian Geology: Northern and Maritime, p. 437-451, Interscience, New York.

Bollinger, G. A., 1973, Seismicity and crustal uplift in the southeastern United States, Am. J. Sci., v. 273A, p. 396-408.

Bradley, E. A., and Bennett, T. J., 1965, Earthquake history of Ohio, Seismol. Soc. Am. Bul1., v. 55, p. 745-752.

Cannon, M. S., Tabet, C. A., and Eckstein, Y., 1980, A low enthalpy convective system in western Ohio, Geotherm. Resour. Coun. Trans., v. 4, p. 105-108. 
Cermak, V., 1976, Paleoclimatic effect on the underground temperature and some problems of correcting heat flow, in Adam, A., ed., Geoelectric and geothermal studies, east-central Europe, Soviet Asia, p. 56-66, Akad. Kiado, Budapest.

Collins, H. R., 1979, Ohio in The Mississippian and Pennsylvanian (Carboniferous) Systems in the United States, U. S. Geol. Surv. Prof. Paper 1110-E, p. E1-E26.

Costain, J. K., Glover, L., and Sinha, A. K., 1980, Low-temperature geothermal resources in the eastern United States, EOS, v. 61, p. 1-3.

Diment, W. H., Urban, T. C., and Revetta, F. A., 1972, Some geophysical anomalies in the eastern United States, in Robertson, E. C., ed., The Nature of the Solid Earth, McGraw Hill, p. 544-574.

Duecker, J. C., 1954, Gravity traverse in northeastern Pennsylvania, Am. Geophys. Union Trans., v. 35, p. 503-507.

Gonterman, J. R., 1973, Petrographic study of the Precambrian basement rocks of Ohio, Ohio State Univ. unpub. M.S. thesis, 139 p.

Gray, C., and Shepps, V. C., 1960, Geologic map of Pennsylvania, Pennsylvania Geol. Surv.

Green, D. A., 1957, Trenton structure in Ohio, Indiana, and northern I1linois, Am. Assoc. Petroleum Geologists Bu11., v. 41, p. 627-642.

Haidarian, M. R., 1976, Geophysical investigation of a gravity minima in northwestern Ohio, Bowling Green State Univ. unpub. M.S. thesis, $56 \mathrm{p}$.

Heiskanen, W. A. and Uotila, U. A., 1956, Gravity survey of the state of Ohio, Ohio Geol. Surv., Rept. Inv. 30.

Hofmann, C. M., Faure, G., and Janssens, A., 1972, Age determination of a granite gneiss from the Precambrian basement of Scioto County, Ohio, Ohio $J$. Sci., v. 72, p. 49-53.

Joyner, W. B., 1960, Heat flow in Pennsylvania and West Virginia, Geophysics, v. 25 , p. $1229-1241$.

Kane, M. F., 1961, Structure of plutons from gravity measurements, U.S. Geol. Surv. Prof. Paper 424-C, p. C258-C259.

Kappelmeyer, 0. and Haenel, R., 1974, Geothermics with special reference to application, Geoexploration Monographs, ser. 1, no. 4, Gebruder Borntraeger, Berlin.

Lachenbruch, A. H., 1968, Preliminary geothermal model for the Sierra Nevada, J. Geophys. Res., v. 73, p. 6977-6989.

, 1970, Crustal temperature and heat production: implications of the Tinear heat flow relation, J. Geophys. Res., v. 75, p. 3291-3300. 
Lapham, D. M., 1975, Interpretation of $\mathrm{K}-\mathrm{Ar}$ and $\mathrm{Rb}-\mathrm{Sr}$ isotopic dates from a Precambrian basement core, Erie County, Pennsylvania, Pennsylvania Geol. Surv. Inf. Circ. 79, p. 26.

Leggette, R. M., 1936, Ground water in northwestern Pennsylvania, Pennsylvania Topog. and Geol. Surv. Bul1. W-3, 215 p.

Lidiak, E. G., Marvin, R. F., Thomas, H. H., and Bass, M. N., 1966, Geochronology of the mid-continent region, United States, 4. Eastern area, $J$. Geophys. Res., v. 71, p. 5427-5438.

McCormick, G. R., 1961, Petrology of Precambrian rocks of Ohio, Ohio Geol. Surv. Rept. Inv. 41,60 p.

Mongelli, F., 1970, Influence of rivers on geotemperatures, Annali di Geofisica, v. 23 , p. 205-212.

Newhart, J. A., 1975, Gravity and magnetic geophysical investigations of Sandusky, Seneca, and portions of Hancock and Wood Counties, Ohio, Bowling Green State Univ., unpub. M.S. thesis, 75 p.

Newport, T. C., 1973, Summary ground-water resources of Clarion County, Pennsylvania, Pennsylvania Topog. and Geol. Surv., Water Resour. Rept. 32 , $42 \mathrm{p}$.

Owens, G. L., 1967, The Precambrian surface of Ohio, Ohio Geol. Surv. Rept. Inv. 64,9 p.

Pakiser, L. C., and Steinhart, J. S., 1964, Explosion seismology in the western hemisphere, in Odishaw, H., ed., Research in Geophysics, p. 123-147, MIT Press, Cambridge, Mass.

Pincus, H. J., 1960, Geological interpretation of major Ohio gravity anomalies (abs.), J. Geophys. Res., v. 65, p. 2517.

Quick, R. C., 1976, Gravity-magnetic survey of portions of Wood and Lucas Counties, Ohio, Bowling Green State Univ. unpub. M.S. thesis, 81 p.

Ross, M. E., 1972, Precambrian quartzo-feldspathic gneiss from the Herman $1 \mathrm{~A}$ weil1, Erie County, Ohio, Ohio J. Sci., v. 72, p. 105-109.

Roy, R. F., Decker, E. R., Blackwe11, D. D., and Birch, F., 1968, Heat flow in the United States, J. Geophys. Res., v. 73, p. 5207-5222.

Rudman, A. J., Summerson, C. H., and Hinze, W. J., 1965, Geology of basement in midwestern United States, Am. Assoc. Petroleum Geologists Bu11., v. 49, p. 894-904.

Sass, J. H., Blackwel1, D. D.., Chapman, D. S., Costain, J. K., Decker, E. R., Lawver, L. A., and Swanberg, C. A., 1980, Heat flow from the crust of the United States, in Touloukian, Y. S., Judd, W. R., and Roy R. F., eds., Physical Properties of Rocks and Minerals, McGraw-Hill, p. 503-548. 
Sass, J. H., Diment, W. H., Lachenbruch, A. H., Marshal 1, B. V., Munroe, R. J., Moses, T. H., Jr., and Urban, T. C., 1976, A heat-flow contour map of the conterminous United States, U.S. Geol. Surv. Open-File Rept. 76-756, $24 \mathrm{p}$.

Saylor, T. E., 1968, The Precambrian in the subsurface of northwestern Pennsylvania and adjoining areas, Pennsylvania Geol. Surv. Inf. Circ. 62, $25 \mathrm{p}$.

Schlorholtz, M., 1979, Terrestrial heat flow in southeastern Ohio, Kent State Univ. unpub. M.S. thesis, $77 \mathrm{p}$.

Scotford, D. M., 1964, Cincinnati Arch: mineralogical-statistical evidence of post-Ordovician origin, Am. Assoc. Petroleum Geologists Bul1., v. 48, p. $427-436$.

Shearrow, G. G., 1957, Geologic cross section of the Paleozoic rocks from northwestern to southeastern Ohio, Ohio Geol. Surv. Rept. Inv. 33, 42 p.

Spa11, H., 1979, Understanding seismicity within the continents, Earthquake Inf. Bul1., v. 11, p. 80-88.

Summerson, C. H., 1962, Precambrian in Ohio and adjoining areas, Ohio Geol. Survey Rept. Inv. 44, 16 p.

U. S. Geological Survey, 1979, Aeromagnetic map of Pennsylvania, Map GP-924, $1: 500000$.

Urban T., 1971, Terrestrial heat flow in the Middle Atlantic States, Univ. Rochester, unpub. Ph.D. dissert., 398 p.

Wallace, R. L., 1978, Gravity survey of the Kent quadrangle, Portage County, Ohio, Kent State Univ., unpub. M.S. thesis, 132 p.

Water Well Journal, 1979, Heat pump update, v. 33, no. 10, p. 50, and unpub. materials on file at National Water Well Association, Worthington, Ohio.

Willard, B., 1962, Pennsylvania geology summarized, Educational Series, v. 4, p. 17 .

Williams, D. W., 1976, The Anna, Ohio, earthquake zone and the establishment of the Anna gravity network, Univ. Michigan, unpub. M.S. thes is, $73 \mathrm{p}$.

Woollard, G. P., 1958, Areas of tectonic activity in the United States as indicated by earthquake epicenters, Am. Geophys. Union Trans., v. 39, p. 1135-1150.

Woollard, G. P., 1972, Regional variations in gravity, in Robertson, E. C., ed., The Nature of the Solid Earth, McGraw Hill, p. 463-505.

Woollard, G. P., and Joesting, H. R., 1964, Bouguer gravity anomaly map of the United States (exclusive of Alaska and Hawaii), Am. Geophys. Union and U.S. Geol. Surv. 
York, J. E., and 01 iver, J. E., 1976, Cretaceous and Cenozoic faulting in eastern North America, Geol. Soc. Am. Bul1., v. 87, p. $1105-1114$. 
APPENDIX A

BOTTOM-HOLE TEMPERATURES IN OIL AND GAS WELLS

IN OHIO 
County

Adams

Allen

Ashl and

Ashtabula

Athens

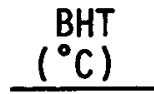

29.40

23.89

22.22

35.56

30.56

30.56

33.89

36.67

20.59

43.89

27.78

32.22

32.22

32.78

39.44

32.22

34.44

23.33

32.78

34.44

50.56

-32. 22

32.22

32.22

45.00

37.78

32.78

42.02

22.78

31.67

23.33

29.44

25.56

34.44

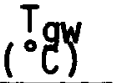

14.17

13.83

13.58

13.58

13.25

12.58

12.58

12.63

12.61

12.67

11.23

10.96

10.96

11.02

11.06

11.01

11.06

11.07

11.03

11.02

10.83

11.08

10.98

11.33

11.08

11.32

13.56

13.72

14.03

13.22

13.56

13.55

13.99

13.22 $\underset{(m)}{\text { Depth }}$

1167.8

619.15

608.8

955.6

995.8

864.41

928.18

1473.71

242.93

1353.62

1123.49

969.57

959.82

1075.33

1246.63

904.34

1018.34

1221.64

954.02

1167.38

1962.91

1085.09

1021.69

1129.59

1889.76

1143.61

1112.52

1481.33

508.10

1054.61

429.16

538.58

513.59

1223.16 $d T / d z$

13.40

17.10

14.94

24.10

17.93

21.92

24.49

17.16

37.40

24.26

15.64

22.64

22.88

20.83

23.34

24.27

23.68

10.30

23.55

20.60

20.56

20.04

21.43

19.01

18.24

23.78

17.76

19.64

18.31

18.01

24.53

31.28

23.94

17.79 


\begin{tabular}{|c|c|c|c|c|}
\hline County & $\begin{array}{r}\text { BHT } \\
\left({ }^{\circ} \mathrm{C}\right) \\
\end{array}$ & $\begin{array}{r}\mathrm{T}_{\mathrm{gw}} \\
\left({ }^{\circ} \mathrm{C}\right)\end{array}$ & $\begin{array}{c}\text { Depth } \\
(\mathrm{m}) \\
\end{array}$ & $\mathrm{dT} / \mathrm{dz}$ \\
\hline \multirow[t]{3}{*}{ Auglaize } & 26.67 & 14.0 & 521.6 & 25.8 \\
\hline & 23.89 & 13.28 & 541.7 & 37.8 \\
\hline & 32.78 & 13.47 & 935.4 & 21.3 \\
\hline \multirow[t]{2}{*}{ Butler } & 28.30 & 14.61 & 895.2 & 13.30 \\
\hline & 30.0 & 14.5 & 1004.62 & 16.53 \\
\hline \multirow[t]{8}{*}{ Carroll } & 41.11 & 11.66 & 1687.07 & 17.78 \\
\hline & 47.22 & 11.45 & 1880.01 & 19.34 \\
\hline & 47.22 & 11.53 & 1881.84 & 19.28 \\
\hline & 18.33 & 11.67 & 373.38 & 19.43 \\
\hline & 40.56 & 11.72 & 1713.89 & 17.13 \\
\hline & 45.0 & 11.75 & 1734.31 & 19.51 \\
\hline & 43.33 & 11.81 & 1680.97 & 19.10 \\
\hline & 46.11 & 11.67 & 1891.28 & 18.51 \\
\hline \multirow[t]{2}{*}{ Champaign } & 28.33 & 13.6 & 686.3 & 21.40 \\
\hline & 27.78 & 14.28 & 815.3 & 17.20 \\
\hline Clarke & 26.11 & 14.53 & 1111.61 & 13.71 \\
\hline \multirow[t]{3}{*}{ Clinton } & 23.9 & 13.8 & 993.4 & 10.5 \\
\hline & 33.9 & 13. & 1019.3 & 20.3 \\
\hline & 25.6 & 13.7 & 1054.7 & 11.6 \\
\hline \multirow[t]{7}{*}{ Columbiana } & 67.50 & 11.31 & 2701.14 & 22.05 \\
\hline & 44.44 & 11.12 & 1804.42 & 19.54 \\
\hline & 71.11 & 11.38 & 3179.67 & 20.11 \\
\hline & 41.67 & 11.61 & 1625.19 & 20.01 \\
\hline & 96.11 & 11.39 & 3134.87 & 29.07 \\
\hline & 65.56 & 11.39 & 1904.70 & 28.60 \\
\hline & 45.56 & 11.61 & 1661.77 & 21.65 \\
\hline \multirow[t]{6}{*}{ Coshocton } & 30.56 & 12.34 & 1056.13 & 18.36 \\
\hline & 46.67 & 12.31 & 1905.91 & 19.07 \\
\hline & 42.78 & 12.29 & 1351.18 & 23.73 \\
\hline & 37.22 & 12.25 & 1234.74 & 21.35 \\
\hline & 49.44 & 12.21 & 2042.16 & 19.25 \\
\hline & 39.44 & 122.38 & 1232.0 & 23.18 \\
\hline
\end{tabular}


County

Crawford

Defiance

Del aware

Erie

Fairfield

Fayette

Frankl in

Fulton

\begin{tabular}{c}
$\begin{array}{c}\text { BHT } \\
\left({ }^{\circ} \mathrm{C}\right)\end{array}$ \\
\hline 33.33 \\
34.44 \\
31.11
\end{tabular}

23.89

22.22

35.56

30.56

38.89

23.89

24.44

40.0

32.8

29.4

40.0

29.4

31.1

28.3

25.6

29.4

34.4

25.6

33.3

33.33

24.44

26.11

24.44

33.33

24.44

42.2

32.8

35.5

31.1

28.3
$T_{\text {gw }}$

$\frac{\left({ }^{\circ} \mathrm{C}\right)}{12.39}$

12.40

12.49

13.83

13.58

13.58

13.25

12.8

2.7

12.83

12.89

12.92

12.5

13.0

12.97

12.89

13.08

13.11

12.89

12.5

12.69

12.75

13.11

12.87

12.84

12.89

13.09

12.88

13.56

13.11

13.17

13.2

12.42
Depth

$\frac{\text { (m) }}{994.56}$

1045.16

1008.58

619.15

608.8

955.6

995.8

1101.1

569.1

569.7

1033.6

1030.6

946.7

862.5

1224.3

1059.6

710.3

702.4

1132.8

1182.8

555.1

1193.8

1139.95

736.09

837.9

725.42

1149.71

691.29

1435.0

1104.7

827.8

1144.7

896.4
$\frac{\mathrm{dT} / \mathrm{dz}}{22.42}$

22.4

19.67

17.1

14.94

24.1

17.93

23.7

20.75

20.4

27.0

19.9

18.4

32.4

13.8

17.7

22.4

18.6

15.0

19.0

24.8

27.55

18.83

16.75

16.75

16.98

18.68

17.87

20.4

18.3

28.0

16.1

18.3 


\begin{tabular}{|c|c|c|c|c|c|}
\hline \multirow[t]{3}{*}{ County } & \multirow{2}{*}{$\begin{array}{r}\begin{array}{c}\text { BHT } \\
\left({ }^{\circ} \mathrm{C}\right)\end{array} \\
31.1\end{array}$} & \multirow{2}{*}{$\begin{aligned}\left.{ }^{{ }^{\circ} \mathrm{CW}}\right) \\
12.47\end{aligned}$} & \multicolumn{2}{|c|}{$\begin{array}{c}\text { Depth } \\
\text { (m) }\end{array}$} & \multirow{2}{*}{$\mathrm{dT} / \mathrm{dz}$} \\
\hline & & & 788.1 & 24.6 & \\
\hline & 26.6 & 13.11 & 874.7 & 16.0 & \\
\hline \multirow[t]{2}{*}{ Gallia } & 21.1 & 14.5 & 494.08 & 14.72 & \\
\hline & 21.11 & 14.44 & 484.94 & 15.13 & \\
\hline \multirow[t]{3}{*}{ Geauga } & 42.22 & 13.29 & 1203.05 & 25.39 & \\
\hline & 35.00 & 11.32 & 1145.13 & 21.87 & \\
\hline & 40.00 & 11.8 & 1242.3 & 17.1 & \\
\hline \multirow[t]{5}{*}{ Hancock } & 30.0 & 13.44 & 647.8 & 26.82 & \\
\hline & 31.1 & 13.28 & 855.2 & 21.6 & \\
\hline & 28.3 & 13.3 & 625.5 & 25.2 & \\
\hline & 25.6 & 13.25 & 578.3 & 22.5 & \\
\hline & 21.1 & 13.47 & 600.9 & 13.4 & \\
\hline \multirow[t]{4}{*}{ Hardin } & 24.4 & 13.42 & 606.9 & 19.0 & \\
\hline & 27.2 & 13.25 & 912.2 & 15.8 & \\
\hline & 27.2 & 13.3 & 863.7 & 16.7 & \\
\hline & 22.8 & 13.58 & 622.8 & 28.6 & \\
\hline \multirow[t]{5}{*}{ Harrison } & 50.6 & 12.17 & 1824.5 & 21.42 & \\
\hline & 27.7 & 12.11 & 422.8 & 39.74 & \\
\hline & 16.7 & 11.86 & 407.2 & 12.84 & \\
\hline & 45.0 & 11.83 & 1875.4 & 18.00 & \\
\hline & 46.7 & 12.08 & 1799.5 & 19.58 & \\
\hline \multirow[t]{2}{*}{ Highland } & 56.4 & 13.56 & 1071.2 & 8.89 & \\
\hline & 56.47 & 13.6 & 729.6 & 18.6 & \\
\hline \multirow[t]{3}{*}{ Hocking } & 26.67 & 13.01 & 800.1 & 18.09 & \\
\hline & 31.67 & 13.02 & 938.17 & 21.24 & \\
\hline & 32.22 & 12.96 & 888.19 & 22.84 & \\
\hline \multirow[t]{6}{*}{ Holmes } & 36.7 & 12.28 & 1141.0 & 22.0 & \\
\hline & 48.9 & 12.28 & 1998.4 & 18.6 & \\
\hline & 53.3 & 12.39 & 1794.0 & 23.2 & \\
\hline & 31.1 & 12.42 & 1003.5 & 19.2 & \\
\hline & 39.4 & 12.36 & 1253.5 & 22.1 & \\
\hline & 48.9 & 12.22 & 2078.9 & 17.9 & \\
\hline
\end{tabular}




\begin{tabular}{|c|c|c|c|c|}
\hline County & $\begin{array}{r}\mathrm{BHT} \\
\left({ }^{\circ} \mathrm{C}\right) \\
\end{array}$ & $\begin{array}{r}T_{g W} \\
\left({ }^{\circ} \mathrm{C}\right) \\
\end{array}$ & $\begin{array}{c}\text { Depth } \\
(\mathrm{m}) \\
\end{array}$ & $\mathrm{dT} / \mathrm{dz}$ \\
\hline \multirow[t]{2}{*}{ Huron } & 32.22 & 12.72 & 1032.97 & 20.09 \\
\hline & 32.22 & 2.76 & 1200.61 & 17.19 \\
\hline \multirow[t]{2}{*}{ Jackson } & 33.9 & 14.25 & 896.4 & 22.7 \\
\hline & 21.1 & 13.94 & 165.9 & 52.9 \\
\hline Jefferson & 51.67 & 12.06 & 2100.07 & 24.72 \\
\hline \multirow[t]{14}{*}{ Knox } & 28.33 & 12.72 & 659.59 & 25.27 \\
\hline & 26.67 & 12.66 & 672.29 & 22.22 \\
\hline & 42.78 & 12.61 & 1751.08 & 18.28 \\
\hline & 32.22 & 12.49 & 974.14 & 21.59 \\
\hline & 33.89 & 12.71 & 1284.73 & 17.43 \\
\hline & 24.44 & 12.68 & 696.77 & 17.66 \\
\hline & 31.67 & 12.52 & 875.08 & 22.67 \\
\hline & 31.67 & 12.55 & 885.44 & 22.36 \\
\hline & 31.11 & 12.72 & 846.73 & 22.53 \\
\hline & 38.89 & 12.61 & 1449.93 & 18.51 \\
\hline & 31.67 & 12.56 & 876.6 & 22.59 \\
\hline & 43.33 & 12.79 & 1466.09 & 21.28 \\
\hline & 27.78 & 12.51 & 954.02 & 16.54 \\
\hline & 27.78 & 12.51 & 937.07 & 16.83 \\
\hline \multirow[t]{3}{*}{ Lawrence } & 33.89 & 14.58 & 982.4 & 20.28 \\
\hline & 46.11 & 14.67 & 890.0 & 36.6 \\
\hline & 30.55 & 14.67 & 1060.5 & 15.4 \\
\hline \multirow[t]{9}{*}{ Licking } & 33.33 & 12.8 & 1373.12 & 15.79 \\
\hline & 35.56 & 12.91 & 1219.2 & 19.65 \\
\hline & 28.36 & 12.68 & 855.27 & 19.32 \\
\hline & 35.0 & 12.88 & 1185.98 & 19.75 \\
\hline & 29.44 & 12.66 & 899.77 & 19.65 \\
\hline & 37.78 & 12.64 & 1552.48 & 17.24 \\
\hline & 40.56 & 12.72 & 1462.74 & 20.0 \\
\hline & 44.44 & 12.66 & 1309.73 & 25.54 \\
\hline & 37.78 & 12.83 & 1344.17 & 19.57 \\
\hline
\end{tabular}




\begin{tabular}{|c|c|c|c|c|}
\hline County & $\begin{array}{r}\mathrm{BHT} \\
\left({ }^{\circ} \mathrm{C}\right) \\
\end{array}$ & $\begin{array}{r}T_{\mathrm{gW}} \\
\left({ }^{\circ} \mathrm{C}\right) \\
\end{array}$ & $\begin{array}{c}\text { Depth } \\
(\mathrm{m}) \\
\end{array}$ & $\mathrm{dT} / \mathrm{dz}$ \\
\hline \multirow[t]{4}{*}{ Logan } & 56.0 & 13.33 & 882.7 & 18.15 \\
\hline & 57.4 & 14.11 & 577.1 & 14.8 \\
\hline & 56.5 & 14.17 & 565.5 & 21.4 \\
\hline & 56.0 & 13.33 & 656.1 & 17.7 \\
\hline \multirow[t]{2}{*}{ Lorain } & 35.6 & 12.6 & 1319.4 & 17.8 \\
\hline & 26.1 & 12.6 & 783.2 & 17.9 \\
\hline \multirow[t]{5}{*}{ Mahoning } & 41.11 & 11.7 & 1537.72 & 20.33 \\
\hline & 46.11 & 11.56 & 152.32 & 22.16 \\
\hline & 45.56 & 11.47 & 1716.33 & 21.94 \\
\hline & 45.56 & 11.47 & 1660.86 & 21.74 \\
\hline & 45.56 & 11.50 & 1667.62 & 21.51 \\
\hline \multirow[t]{2}{*}{ Marion } & 27.22 & 12.93 & 2447.54 & 16.67 \\
\hline & 31.11 & 13.04 & 357.1 & 22.23 \\
\hline \multirow[t]{3}{*}{ Medina } & 55.00 & 12.39 & 2050.69 & 21.91 \\
\hline & 31.11 & 12.44 & 1108.25 & 17.9 \\
\hline & 31.11 & 12.44 & 949.74 & 17.9 \\
\hline \multirow[t]{2}{*}{ Meigs } & 50.6 & 14.5 & 1525.0 & 24.2 \\
\hline & 57.8 & 14.2 & 1610.1 & 27.6 \\
\hline \multirow[t]{3}{*}{ Mercer } & 22.8 & 13.2 & 574.6 & 17.6 \\
\hline & 30.56 & 12.28 & 396.24 & 48.07 \\
\hline & 31.11 & 13.24 & 956.16 & 19.98 \\
\hline \multirow[t]{2}{*}{ Mi ami } & 30.0 & 14.5 & 933.91 & 17.82 \\
\hline & 27.22 & 14.5 & 932.99 & 14.7 \\
\hline \multirow[t]{8}{*}{ Morgan } & 37.78 & 13.03 & 1493.82 & 17.43 \\
\hline & 38.89 & 13.08 & 1363.98 & 19.94 \\
\hline & 43.33 & 13.29 & 1642.87 & 19.44 \\
\hline & 33.89 & 12.91 & 1208.44 & 18.38 \\
\hline & 40.0 & 12.93 & 1283.21 & 22.25 \\
\hline & 21.11 & 11.66 & 1645.62 & 5.72 \\
\hline & 43.33 & 13.0 & 1533.14 & 21.05 \\
\hline & 42.78 & 13.17 & 1644.09 & 19.15 \\
\hline \multirow[t]{2}{*}{ Morrow } & 35.0 & 12.92 & 1123.8 & 20.84 \\
\hline & 23.89 & 14.0 & 921.72 & 25.17 \\
\hline
\end{tabular}




\begin{tabular}{|c|c|c|c|c|}
\hline County & $\begin{array}{r}\text { BHT } \\
\left({ }^{\circ} \mathrm{C}\right) \\
\end{array}$ & $\begin{array}{c}\mathrm{T}_{\mathrm{gw}} \\
\left({ }^{\circ} \mathrm{C}\right) \\
\end{array}$ & $\begin{array}{c}\text { Depth } \\
(\mathrm{m}) \\
\end{array}$ & $\mathrm{dT} / \mathrm{dz}$ \\
\hline & 35.56 & 12.82 & 1211.88 & 19.84 \\
\hline & 34.44 & 12.83 & 1264.62 & 18.07 \\
\hline & 31.11 & 12.86 & 999.44 & 18.83 \\
\hline & 29.44 & 12.92 & 1386.84 & 12.62 \\
\hline & 30.56 & 12.78 & 1030.22 & 18.39 \\
\hline & 27.78 & 12.79 & 1032.27 & 15.5 \\
\hline & 34.44 & 12.92 & 1124.71 & 20.3 \\
\hline & 27.78 & 11.83 & 972.3 & 16.44 \\
\hline & 35.0 & 12.9 & 1189.94 & 21.98 \\
\hline \multirow[t]{15}{*}{ Musk ingum } & 35.0 & 12.72 & 1048.51 & 22.57 \\
\hline & 45.6 & 12.47 & 1353.31 & 25.69 \\
\hline & 41.11 & 12.68 & 1552.04 & 17.49 \\
\hline & 43.89 & 12.43 & 1261.07 & 26.26 \\
\hline & 33.33 & 12.43 & 1161.59 & 19.07 \\
\hline & 36.11 & 12.6 & 1548.08 & 19.23 \\
\hline & 36.67 & 12.37 & 1309.42 & 19.57 \\
\hline & 35.56 & 12.49 & 1085.70 & 26.33 \\
\hline & 23.89 & 12.44 & 1383.79 & 18.81 \\
\hline & 34.44 & 12.57 & 1025.35 & 22.68 \\
\hline & 28.89 & 12.56 & 942.44 & 18.54 \\
\hline & 29.44 & 12.57 & 1004.32 & 17.94 \\
\hline & 35.0 & 12.76 & 1062.53 & 22.23 \\
\hline & 35.56 & 12.54 & 1099.11 & 22.2 \\
\hline & 35.56 & 12.49 & 1341.12 & 18.14 \\
\hline \multirow[t]{2}{*}{ Noble } & 55.6 & 13.11 & 1817.1 & 23.8 \\
\hline & 42.2 & 13.08 & 1791.9 & 16.5 \\
\hline ottawa & 22.8 & 12.5 & 586.5 & 18.5 \\
\hline \multirow[t]{2}{*}{ Paulding } & 31.1 & 12.97 & 597.5 & 31.98 \\
\hline & 23.9 & 13.02 & 443.8 & 26.3 \\
\hline \multirow[t]{4}{*}{ Perry } & 43.9 & 12.89 & 1885.8 & 16.7 \\
\hline & 32.2 & 12.7 & 1038.8 & 19.3 \\
\hline & 32.8 & 12.78 & 1078.2 & 19.1 \\
\hline & 28.8 & 12.67 & 884.8 & 18.9 \\
\hline
\end{tabular}




\begin{tabular}{|c|c|c|c|c|}
\hline County & $\begin{array}{r}\mathrm{BHT} \\
\left({ }^{\circ} \mathrm{C}\right) \\
\end{array}$ & $\begin{array}{r}T_{g w} \\
\left({ }^{\circ} \mathrm{C}\right) \\
\end{array}$ & $\begin{array}{c}\text { Depth } \\
(\mathrm{m})\end{array}$ & $\mathrm{dT} / \mathrm{dz}$ \\
\hline & 29.4 & 12.86 & 934.8 & 18.3 \\
\hline & 28.3 & 12.67 & 973.6 & 16.6 \\
\hline & 27.7 & 12.92 & 914.4 & 16.7 \\
\hline & 31.7 & 13.05 & 1117.5 & 17.2 \\
\hline & 28.8 & 12.89 & 1002.5 & 16.4 \\
\hline & 31.7 & 12.92 & 1127.9 & 17.7 \\
\hline & 30.6 & 12.72 & 976.0 & 18.91 \\
\hline & 27.7 & 13.3 & 1075.1 & 13.78 \\
\hline & 28.8 & 13.25 & 840.3 & 19.20 \\
\hline \multirow[t]{2}{*}{ Pickaway } & 28.8 & 13.11 & 921.7 & 17.61 \\
\hline & 38.9 & 13.19 & 247.6 & 20.67 \\
\hline \multirow[t]{2}{*}{ Pike } & 33.89 & 13.67 & 494.08 & 18.24 \\
\hline & 26.67 & 13.64 & 1176.53 & 15.47 \\
\hline \multirow[t]{7}{*}{ Portage } & 41.67 & 12.67 & 1325.88 & 22.36 \\
\hline & 35.0 & 12.04 & 1387.45 & 18.47 \\
\hline & 36.11 & 12.17 & 1311.55 & 17.36 \\
\hline & 42.78 & 12.0 & 1396.59 & 21.64 \\
\hline & 41.11 & 12.24 & 1492.0 & 22.88 \\
\hline & 35.56 & 11.98 & 1328.01 & 18.89 \\
\hline & 28.33 & 11.79 & 1354.53 & 29.18 \\
\hline \multirow[t]{3}{*}{ Ross } & 26.6 & 13.36 & 748.2 & 18.45 \\
\hline & 28.8 & 13.22 & 1008.0 & 15.94 \\
\hline & 30.0 & 13.22 & 1041.3 & 16.6 \\
\hline \multirow[t]{7}{*}{ Sandusky } & 24.4 & 12.83 & 677.7 & 17.9 \\
\hline & 28.3 & 12.89 & 842.7 & 18.97 \\
\hline & 29.4 & 12.61 & 731.1 & 23.96 \\
\hline & 28.3 & 12.94 & 671.9 & 23.95 \\
\hline & 29.4 & 12.58 & 822.3 & 21.24 \\
\hline & 29.4 & 12.83 & 676.5 & 25.65 \\
\hline & 24.4 & 12.83 & 848.5 & 14.14 \\
\hline \multirow[t]{2}{*}{ Scioto } & 32.78 & 14.26 & 1712.06 & 14.91 \\
\hline & 21.67 & 14.42 & 1316.74 & 23.22 \\
\hline
\end{tabular}




\begin{tabular}{|c|c|c|c|c|}
\hline County & $\begin{array}{r}\text { BHT } \\
\left({ }^{\circ} \mathrm{C}\right) \\
\end{array}$ & $\begin{array}{l}\mathrm{T}_{\mathrm{gw}} \\
\left({ }^{\circ} \mathrm{C}\right)\end{array}$ & $\begin{array}{c}\text { Depth } \\
\text { (m) }\end{array}$ & $\mathrm{dT} / \mathrm{dz}$ \\
\hline \multirow[t]{3}{*}{ Stark } & 39.44 & 12.21 & 1324.97 & 21.65 \\
\hline & 41.11 & 12.02 & 1527.05 & 20.26 \\
\hline & 60.0 & 11.86 & 2439.31 & 20.98 \\
\hline \multirow[t]{2}{*}{ Warren } & 31.7 & 14.5 & 893.0 & 19.9 \\
\hline & 29.4 & 13.9 & 898.5 & 17.9 \\
\hline \multirow[t]{6}{*}{ Washington } & 444.4 & 13.5 & 1758.0 & 17.9 \\
\hline & 23.3 & 13.7 & 413.9 & 25.0 \\
\hline & 42.8 & 13.9 & 1586.0 & 18.6 \\
\hline & 39.4 & 13.75 & 1096.8 & 24.1 \\
\hline & 49.4 & 13.9 & 1351.7 & 26.7 \\
\hline & 35.0 & 13.5 & 1598.8 & 13.7 \\
\hline \multirow[t]{9}{*}{ Wayne } & 32.2 & 12.5 & 1008.9 & 20.1 \\
\hline & 44.4 & 12.6 & 1752.5 & 18.5 \\
\hline & 44.4 & 12.6 & 1625.3 & 20.0 \\
\hline & 41.7 & 12.4 & 1159.6 & 25.9 \\
\hline & 43.3 & 12.4 & 1534.7 & 20.5 \\
\hline & 25.6 & 12.4 & 778.4 & 17.6 \\
\hline & 40.0 & 12.4 & 972.9 & 29.3 \\
\hline & 34.4 & 12.5 & 942.4 & 24.0 \\
\hline & 30.0 & 12.6 & 1179.4 & 15.3 \\
\hline \multirow[t]{6}{*}{ Wood } & 31.1 & 12.9 & 862.2 & 21.9 \\
\hline & 26.1 & 12.8 & 717.0 & 19.4 \\
\hline & 21.1 & 12.9 & 595.7 & 14.6 \\
\hline & 29.4 & 13.0 & 844.8 & 20.1 \\
\hline & 28.8 & 12.9 & 847.9 & 19.5 \\
\hline & 26.6 & 12.75 & 784.8 & 18.4 \\
\hline \multirow[t]{5}{*}{ Wyandot } & 29.4 & 13.1 & 771.6 & 16.3 \\
\hline & 27.7 & 13.2 & 642.9 & 23.6 \\
\hline & 26.6 & 13.2 & 884.8 & 15.7 \\
\hline & 26.6 & 13.2 & 875.0 & 15.9 \\
\hline & 29.4 & 13.1 & 703.6 & 24.2 \\
\hline
\end{tabular}




\author{
APPENDIX B \\ BOTTOM-HOLE TEMPERATURES IN OIL AND GAS WELLS \\ IN PENNSYL VANIA AND ADJACENT AREAS OF \\ MARYLAND AND WEST VIRGINIA
}




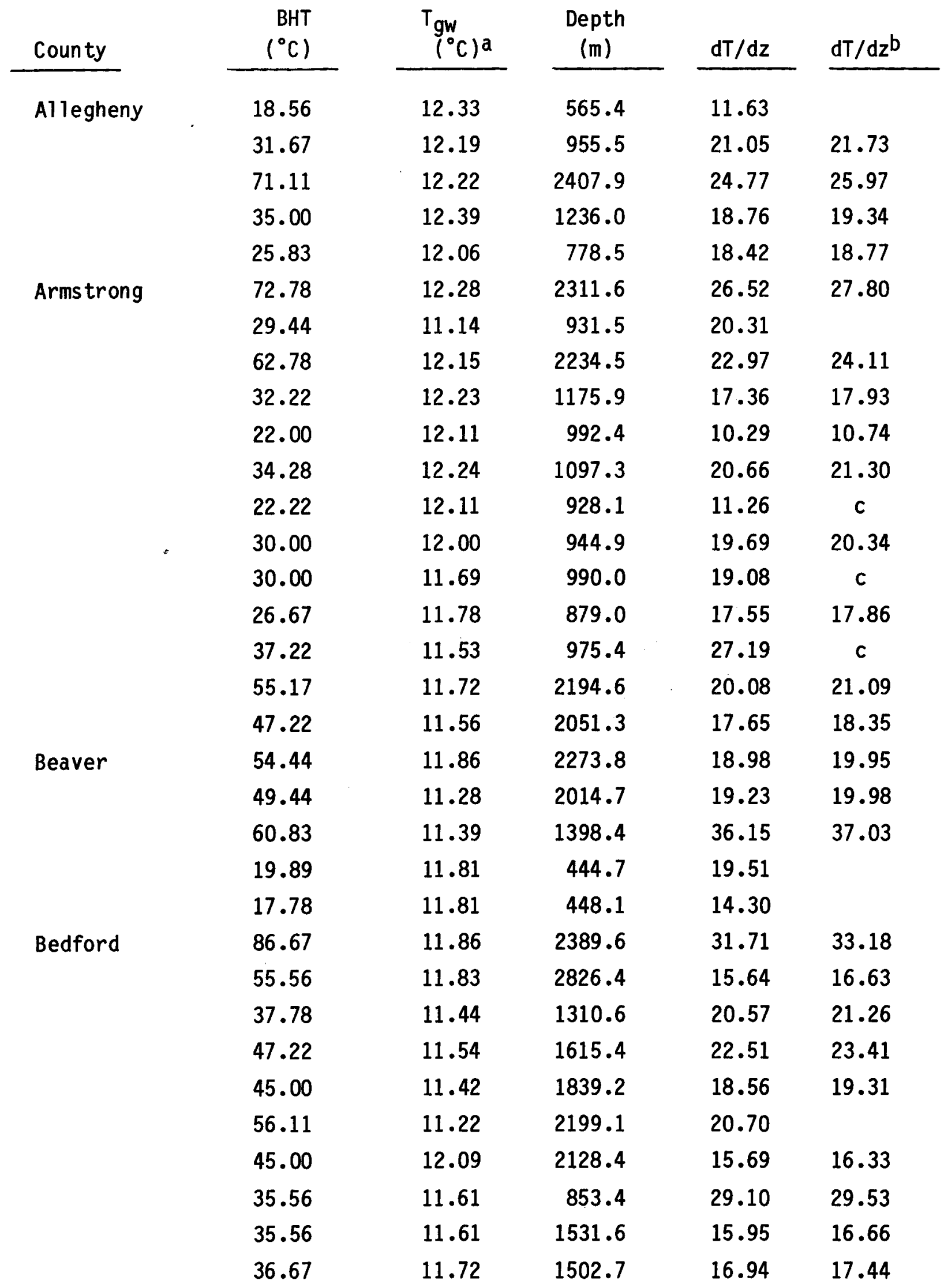




\begin{tabular}{|c|c|c|c|c|c|}
\hline County & $\begin{array}{l}\mathrm{BHT} \\
\left({ }^{\circ} \mathrm{C}\right)\end{array}$ & $\stackrel{\mathrm{T}}{g \mathrm{~W}}_{\left({ }^{\circ} \mathrm{C}\right)^{\mathrm{a}}}$ & $\begin{array}{c}\text { Depth } \\
(m)\end{array}$ & $\mathrm{dT} / \mathrm{dz}$ & $d T / d z^{b}$ \\
\hline \multirow[t]{5}{*}{ Blair } & 47.78 & 11.92 & 1774.9 & 20.56 & 21.38 \\
\hline & 58.33 & 11.94 & 2822.4 & 16.62 & 17.66 \\
\hline & 46.11 & 12.08 & 2122.6 & 16.26 & 16.93 \\
\hline & 64.44 & 12.06 & 2164.1 & 24.55 & 25.76 \\
\hline & 34.06 & 11.78 & 1020.5 & 22.50 & \\
\hline \multirow[t]{5}{*}{ Bradford } & 98.89 & 10.22 & 3914.5 & 22.83 & 24.10 \\
\hline & 58.89 & 10.17 & 2288.1 & 21.58 & 22.10 \\
\hline & 35.00 & 10.37 & 1227.1 & 20.58 & 21.17 \\
\hline & 45.83 & 10.11 & 2012.9 & 18.02 & 18.71 \\
\hline & 36.39 & 10.01 & 1402.1 & 19.23 & 19.76 \\
\hline \multirow[t]{8}{*}{ Butler } & 20.44 & 11.64 & 527.3 & 17.72 & \\
\hline & 35.00 & 11.31 & 1038.5 & 23.50 & 24.20 \\
\hline & 21.39 & 11.06 & 614.2 & 17.70 & 18.07 \\
\hline & 19.78 & 11.70 & 568.5 & 15.02 & 15.38 \\
\hline & 25.39 & 11.92 & 810.2 & 17.28 & 17.60 \\
\hline & 28.78 & 11.81 & 807.7 & 21.84 & 22.21 \\
\hline & 34.72 & 11.22 & 1689.8 & 14.16 & \\
\hline & 51.67 & 11.25 & 2316.5 & 17.68 & c \\
\hline \multirow[t]{13}{*}{ Cambria } & 65.56 & 12.36 & 2468.9 & 21.82 & 22.89 \\
\hline & 34.72 & 12.33 & 1524.0 & 14.99 & 15.69 \\
\hline & 63.89 & 12.17 & 2225.0 & 23.57 & 24.73 \\
\hline & 84.17 & 12.39 & 2718.8 & 26.70 & 17.95 \\
\hline & 60.56 & 12.50 & 2447.8 & 19.88 & \\
\hline & 65.00 & 12.44 & 2923.0 & 18.17 & 19.29 \\
\hline & 66.39 & 12.39 & 2593.8 & 21.07 & 22.10 \\
\hline & 72.50 & 12.39 & 2606.0 & 23.34 & 24.47 \\
\hline & 70.00 & 12.36 & 2781.6 & 20.95 & 22.22 \\
\hline & 73.89 & 12.11 & 2503.6 & 24.98 & 27.17 \\
\hline & 69.72 & 12.11 & 2578.6 & 22.61 & 23.70 \\
\hline & 73.89 & 12.17 & 2432.3 & 25.70 & 26.93 \\
\hline & 86.39 & 12.17 & 2489.9 & 30.18 & 31.58 \\
\hline \multirow[t]{2}{*}{ Cameron } & 59.44 & 11.06 & 2036.1 & 24.13 & 25.02 \\
\hline & 43.33 & 10.97 & 1822.1 & 18.06 & 18.79 \\
\hline
\end{tabular}




\begin{tabular}{|c|c|c|c|c|c|}
\hline County & $\begin{array}{l}\text { BHT } \\
\left({ }^{\circ} \mathrm{C}\right)\end{array}$ & $\underset{\left({ }^{\circ} \mathrm{C}\right) \mathrm{a}}{\mathrm{T}}$ & $\begin{array}{l}\text { Depth } \\
\text { (m) }\end{array}$ & $\mathrm{dT} / \mathrm{dz}$ & $\mathrm{dT} / \mathrm{dz} \mathrm{z}^{\mathrm{b}}$ \\
\hline & 51.11 & 11.14 & 1790.7 & 22.71 & \\
\hline & 50.56 & 11.15 & 1872.4 & 21.39 & \\
\hline & 56.56 & 11.06 & 1976.3 & 23.38 & 24.26 \\
\hline & 66.67 & 11.00 & 1983.0 & 28.51 & 29.53 \\
\hline & 59.61 & 11.06 & 1823.3 & 27.08 & 28.08 \\
\hline & 52.78 & 11.06 & 1984.6 & 21.35 & $c$ \\
\hline & 60.00 & 11.00 & 2048.3 & 24.28 & 25.18 \\
\hline & 16.50 & 11.00 & 914.4 & 6.22 & 6.60 \\
\hline & 58.33 & 11.00 & 1964.4 & 24.47 & 25.38 \\
\hline & 14.17 & 11.00 & 766.3 & 4.30 & \\
\hline \multirow[t]{2}{*}{ Carbon } & 44.17 & 11.39 & 978.4 & 34.58 & 35.51 \\
\hline & 41.11 & 11.42 & 1644.7 & 18.40 & 19.16 \\
\hline \multirow[t]{3}{*}{ Centre } & 58.06 & 11.67 & 2468.9 & 19.02 & 19.98 \\
\hline & 60.00 & 11.61 & 2179.3 & 22.52 & 23.64 \\
\hline & 70.00 & 11.33 & 4773.8 & 12.37 & 13.11 \\
\hline \multirow[t]{2}{*}{ Clinton } & 54.44 & 11.39 & 2580.7 & 16.88 & 17.74 \\
\hline & 21.56 & 11.28 & 608.4 & 17.78 & \\
\hline \multirow[t]{16}{*}{ Clarion } & 25.56 & 11.06 & 696.2 & 21.78 & 22.17 \\
\hline & 14.78 & 11.17 & 693.42 & 5.45 & 5.67 \\
\hline & 19.67 & 11.03 & 557.82 & 16.37 & 16.37 \\
\hline & 24.44 & 11.17 & 960.1 & 14.28 & $c$ \\
\hline & 21.11 & 11.17 & 798.0 & 12.96 & 13.23 \\
\hline & 23.89 & 11.33 & 640.1 & 20.60 & \\
\hline & 29.31 & 11.33 & 896.1 & 20.76 & \\
\hline & 32.22 & 11.33 & 954.6 & 22.60 & \\
\hline & 23.61 & 11.08 & 774.2 & 16.85 & $c$ \\
\hline & 22.00 & 11.22 & 762.0 & 14.73 & \\
\hline & 16.67 & 11.04 & 538.3 & 11.08 & 11.41 \\
\hline & 19.28 & 11.28 & 707.1 & 11.82 & 12.11 \\
\hline & 23.33 & 11.17 & 740.7 & 17.13 & 17.46 \\
\hline & 23.33 & 11.17 & 742.2 & 17.10 & 17.42 \\
\hline & 25.28 & 11.17 & 808.0 & 18.15 & 18.47 \\
\hline & 28.89 & 11.22 & 809.5 & 22.68 & \\
\hline
\end{tabular}




\begin{tabular}{|c|c|c|c|c|c|}
\hline County & $\begin{array}{r}\text { BHT } \\
\left({ }^{\circ} \mathrm{C}\right) \\
\end{array}$ & $\left.{ }^{\mathrm{T} g \mathrm{w}}{ }^{\circ} \mathrm{C}\right)^{\mathrm{a}}$ & $\begin{array}{c}\text { Depth } \\
\text { (m) }\end{array}$ & $\mathrm{dT} / \mathrm{dz}$ & $\mathrm{dT} / \mathrm{dz}{ }^{\mathrm{b}}$ \\
\hline & 23.89 & 11.17 & 869.6 & 15.16 & \\
\hline & 20.83 & 11.17 & 789.4 & 12.74 & \\
\hline & 29.17 & 11.06 & 758.3 & 24.88 & \\
\hline & 23.89 & 11.06 & 574.2 & 23.60 & \\
\hline & 20.56 & 11.31 & 765.0 & 12.58 & \\
\hline & 22.50 & 11.11 & 634.0 & 18.87 & \\
\hline & 21.81 & 11.04 & 865.6 & 12.89 & \\
\hline & 17.36 & 11.03 & 636.4 & 10.45 & \\
\hline & 19.28 & 11.06 & 939.7 & 9.04 & \\
\hline & 28.75 & 11.17 & 634.0 & 29.14 & \\
\hline & 20.56 & 11.10 & 752.9 & 13.09 & \\
\hline & 20.00 & 11.10 & 1525.8 & 5.95 & \\
\hline & 20.28 & 11.17 & 666.0 & 14.34 & \\
\hline & 22.78 & 11.09 & 794.3 & 15.30 & \\
\hline & 31.67 & 11.00 & 749.2 & 28.75 & 29.20 \\
\hline & 21.11 & 10.98 & 792.5 & 13.30 & 13.58 \\
\hline & 17.22 & $10: 97$ & 369.7 & 18.42 & \\
\hline & 28.94 & 10.96 & 912.3 & 20.40 & 20.73 \\
\hline & 68.89 & 11.06 & 2409.7 & 24.31 & 25.47 \\
\hline & 60.14 & 11.06 & 1760.2 & 28.38 & 29.42 \\
\hline & 51.94 & 11.06 & 1767.8 & 23.54 & c \\
\hline & 53.33 & 11.06 & 1699.6 & 25.33 & 26.29 \\
\hline & 56.11 & 11.00 & 2265.6 & 20.18 & 20.69 \\
\hline & 42.78 & 11.00 & 1645.9 & 19.67 & 20.47 \\
\hline & 52.78 & 10.94 & 2966.0 & 21.61 & 22.43 \\
\hline \multirow[t]{8}{*}{ Clearfield } & 67.78 & 12.11 & 2529.8 & 22.27 & 23.36 \\
\hline & 65.56 & 11.28 & 1866.9 & 29.56 & \\
\hline & 70.33 & 11.32 & 2136.6 & 28.02 & \\
\hline & 73.89 & 11.67 & 2392.7 & 26.34 & \\
\hline & 75.56 & 12.00 & 2498.4 & 25.75 & 26.98 \\
\hline & 56.11 & 11.67 & 2254.9 & 19.98 & 20.99 \\
\hline & 63.33 & 11.67 & 2380.5 & 21.99 & 23.06 \\
\hline & 65.56 & 11.67 & 2270.8 & 24.05 & 25.03 \\
\hline
\end{tabular}


County

Crawford

\begin{tabular}{|c|c|c|c|c|}
\hline $\begin{array}{r}\text { BHT } \\
\left({ }^{\circ} \mathrm{C}\right) \\
\end{array}$ & $\begin{array}{l}T_{g w} \\
\left({ }^{\circ} \mathrm{C}\right)^{a}\end{array}$ & $\begin{array}{c}\text { Depth } \\
\text { (m) }\end{array}$ & $\mathrm{dT} / \mathrm{dz}$ & $\mathrm{dT} / \mathrm{dz} \mathrm{b}^{\mathrm{b}}$ \\
\hline 62.22 & 11.67 & 2313.4 & 22.14 & 23.24 \\
\hline 75.56 & 11.39 & 2211.3 & 29.42 & 30.81 \\
\hline 78.33 & 11.89 & 2484.1 & 27.08 & 28.36 \\
\hline 67.22 & 11.78 & 2461.3 & 22.81 & 23.92 \\
\hline 67.22 & 11.48 & 2188.6 & 26.50 & 27.78 \\
\hline 60.00 & 11.32 & 2354.0 & 20.95 & 21.99 \\
\hline 78.33 & 11.44 & 2316.5 & 29.26 & 30.63 \\
\hline 68.11 & 11.28 & 2042.2 & 28.25 & 29.27 \\
\hline 73.33 & 11.67 & 2315.0 & 26.99 & 28.28 \\
\hline 70.28 & 11.30 & 2301.2 & 25.97 & 27.21 \\
\hline 58.33 & 11.17 & 1996.4 & 23.99 & 24.59 \\
\hline 33.33 & 11.03 & 1200.6 & 19.06 & 19.63 \\
\hline 37.78 & 10.89 & 1206.7 & 22.86 & \\
\hline 36.11 & 10.83 & 1323.1 & 19.55 & \\
\hline 38.33 & 10.91 & 1233.2 & 22.80 & 23.44 \\
\hline 35.00 & 10.89 & 1248.5 & 19.80 & 20.37 \\
\hline 33.33 & 10.78 & 1314.3 & 17.57 & 18.09 \\
\hline 36.11 & 10.92 & 1250.0 & 20.66 & 21.25 \\
\hline 31.67 & 10.92 & 1163.1 & 18.32 & 18.87 \\
\hline 34.44 & 10.92 & 1233.2 & 19.56 & 20.13 \\
\hline 43.33 & 11.00 & 1242.7 & 26.67 & 27.39 \\
\hline 34.44 & 10.93 & 1293.6 & 18.62 & 18.16 \\
\hline 36.67 & 10.89 & 1312.2 & 20.11 & 20.68 \\
\hline 38.33 & 10.91 & 1294.2 & 21.70 & 22.31 \\
\hline 43.33 & 10.89 & 1609.6 & 20.55 & 21.37 \\
\hline 45.00 & 10.92 & 1460.3 & 23.84 & c \\
\hline 42.22 & 10.72 & 1006.7 & 19.38 & 20.16 \\
\hline 45.00 & 10.74 & 1553.0 & 22.50 & 23.39 \\
\hline 59.44 & 11.11 & 1874.4 & 6.21 & 27.18 \\
\hline 62.94 & 11.18 & 2194.6 & 23.92 & 24.50 \\
\hline 74.44 & 11.19 & 2127.5 & 30.16 & \\
\hline 48.33 & 11.06 & 1978.2 & 19.14 & 19.88 \\
\hline 56.78 & 11.06 & 1979.3 & 23.46 & 24.33 \\
\hline
\end{tabular}




\begin{tabular}{|c|c|c|c|c|c|}
\hline County & $\begin{array}{l}\mathrm{BHT} \\
\left({ }^{\circ} \mathrm{C}\right)\end{array}$ & 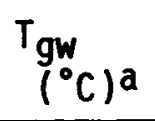 & $\begin{array}{l}\text { Depth } \\
\text { (m) }\end{array}$ & $\mathrm{dT} / \mathrm{dz}$ & $\mathrm{dT} / \mathrm{dz} \mathrm{b}^{\mathrm{b}}$ \\
\hline & 66.67 & 11.22 & 2008.0 & 28.04 & \\
\hline & 54.44 & 11.00 & 1969.0 & 22.41 & 23.25 \\
\hline & 57.22 & 10.97 & 1865.4 & 25.21 & 26.14 \\
\hline & 18.61 & 10.89 & 664.5 & 12.18 & 12.18 \\
\hline & 23.33 & 10.89 & 492.3 & 26.95 & $c$ \\
\hline & 56.44 & 11.14 & 1966.9 & 23.39 & 24.27 \\
\hline & 68.33 & 11.02 & 2471.9 & 23.47 & 24.59 \\
\hline & 59.17 & 11.04 & 1859.3 & 26.32 & 27.29 \\
\hline & 61.11 & 11.11 & 2179.3 & 23.27 & 24.41 \\
\hline \multirow[t]{8}{*}{ Erie } & 44.44 & 10.87 & 1241.1 & 27.73 & 28.46 \\
\hline & 30.56 & 10.83 & 1148.5 & 17.64 & 18.19 \\
\hline & 40.56 & 10.69 & 1361.8 & 22.43 & 23.04 \\
\hline & 22.89 & 10.94 & 1068.6 & 11.51 & \\
\hline & 30.56 & 10.94 & 874.8 & 23.23 & 23.59 \\
\hline & 32.78 & 10.94 & 1001.3 & 22.49 & 23.17 \\
\hline & 20.00 & 10.68 & 378.0 & 26.81 & 27.39 \\
\hline & 43.33 & 10.74 & 1260.3 & 26.50 & 27.20 \\
\hline \multirow[t]{16}{*}{ Fayette } & 39.44 & 12.19 & 1197.3 & 23.35 & c \\
\hline & 74.44 & 13.18 & 2545.7 & 24.36 & 25.54 \\
\hline & 27.61 & 13.33 & 911.4 & 16.21 & 16.52 \\
\hline & 37.78 & 13.33 & 1173.5 & 21.39 & 22.05 \\
\hline & 75.56 & 13.06 & 2011.7 & 31.55 & 32.69 \\
\hline & 24.72 & 13.00 & 701.0 & 17.48 & 17.85 \\
\hline & 74.44 & 13.06 & 2069.6 & 30.11 & 31.20 \\
\hline & 69.44 & 13.06 & 2380.5 & 24.00 & 25.18 \\
\hline & 79.44 & 12.78 & 2816.7 & 23.93 & 25.35 \\
\hline & 70.56 & 12.18 & 2148.8 & 27.56 & \\
\hline & 33.50 & 12.19 & 972.9 & 22.61 & 23.32 \\
\hline & 27.22 & 12.85 & 1219.2 & 12.09 & 12.55 \\
\hline & 65.56 & 12.56 & 2727.4 & 19.65 & 20.62 \\
\hline & 64.44 & 12.91 & 2684.4 & 19.42 & 20.39 \\
\hline & 23.89 & 13.33 & 807.7 & 13.58 & 13.89 \\
\hline & 68.61 & 13.18 & 2427.4 & 23.13 & c \\
\hline
\end{tabular}




\begin{tabular}{|c|c|c|c|c|c|}
\hline County & $\begin{array}{l}\text { BHT } \\
\left({ }^{\circ} \mathrm{C}\right)\end{array}$ & ${ }_{\left({ }^{\circ} \mathrm{C}\right)^{\mathrm{a}}}$ & $\begin{array}{l}\text { Depth } \\
\text { (m) }\end{array}$ & $\mathrm{dT} / \mathrm{dz}$ & $\mathrm{dT} / \mathrm{dz} \mathrm{b}^{\mathrm{b}}$ \\
\hline & 90.00 & 13.24 & 3291.8 & 23.53 & 24.91 \\
\hline & 80.56 & 13.39 & 2910.8 & 23.32 & c \\
\hline & 72.50 & 13.33 & 2407.9 & 24.89 & \\
\hline & 69.44 & 13.33 & 2133.6 & 26.68 & 28.00 \\
\hline & 71.67 & 13.14 & 2407.9 & 24.62 & 25.82 \\
\hline & 103.61 & 13.24 & 3627.1 & 25.13 & 26.57 \\
\hline & 73.33 & 13.19 & 2313.4 & 26.34 & 27.63 \\
\hline & 75.00 & 13.24 & 2417.1 & 25.88 & 17.14 \\
\hline \multirow[t]{5}{*}{ Forest } & 14.11 & 10.89 & 645.0 & 5.24 & 5.47 \\
\hline & 46.11 & 10.83 & 1837.0 & 19.53 & 19.92 \\
\hline & 46.11 & 10.83 & 1870.6 & 19.17 & 19.92 \\
\hline & 17.39 & 10.86 & 314.2 & 23.02 & c \\
\hline & 54.44 & 10.89 & 2086.1 & 21.19 & 21.98 \\
\hline Ful ton & 31.11 & 11.11 & 874.8 & 23.69 & 24.06 \\
\hline \multirow[t]{6}{*}{ Greene } & 26.56 & 13.41 & 910.1 & 14.95 & 15.25 \\
\hline & 32.78 & 13.39 & 993.6 & 20.13 & \\
\hline & 26.67 & 13.33 & 951.0 & 14.48 & \\
\hline & 32.78 & 13.34 & 975.7 & 20.56 & $c$ \\
\hline & 32.89 & 12.59 & 2331.7 & 8.77 & 9.34 \\
\hline & 75.83 & 12.96 & 2639.6 & 24.10 & 25.26 \\
\hline \multirow[t]{13}{*}{ Indiana } & 35.00 & 12.36 & 1164.3 & 19.97 & 20.58 \\
\hline & 75.56 & 12.42 & 2581.7 & 24.75 & 25.93 \\
\hline & 76.67 & 12.25 & 2455.2 & 26.57 & \\
\hline & 80.00 & 12.27 & 2471.9 & 27.74 & 29.05 \\
\hline & 80.83 & 12.36 & 2118.4 & 32.80 & 33.96 \\
\hline & 71.11 & 12.36 & 2285.4 & 26.06 & \\
\hline & 52.22 & 12.33 & 1828.8 & 22.18 & \\
\hline & 28.89 & 12.31 & 960.1 & 17.84 & \\
\hline & 36.67 & 12.14 & 1066.8 & 23.66 & \\
\hline & 21.89 & 12.42 & 678.1 & 12.84 & \\
\hline & 81.67 & 12.42 & 2255.5 & 31.12 & 32.59 \\
\hline & 58.44 & 12.44 & 2286.0 & 20.39 & 21.43 \\
\hline & 26.83 & 12.34 & 1066.8 & 13.98 & 14.50 \\
\hline
\end{tabular}




\begin{tabular}{|c|c|c|c|c|c|}
\hline County & $\begin{array}{r}\text { BHT } \\
\left({ }^{\circ} \mathrm{C}\right) \\
\end{array}$ & 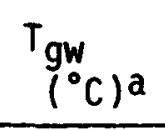 & $\begin{array}{c}\text { Depth } \\
(\mathrm{m})\end{array}$ & $\mathrm{dT} / \mathrm{dz}$ & $\mathrm{dT} / \mathrm{dz} \mathrm{b}^{\mathrm{b}}$ \\
\hline & 54.44 & 12.35 & 2334.2 & 18.27 & 19.22 \\
\hline & 74.44 & 12.50 & 2530.1 & 24.95 & \\
\hline & 73.33 & 12.47 & 2301.2 & 26.80 & \\
\hline & 20.56 & 11.78 & 1001.0 & 9.04 & \\
\hline & 62.78 & 11.94 & 2203.7 & 23.39 & 24.55 \\
\hline & 68.33 & 11.81 & 2329.0 & 24.59 & 25.78 \\
\hline & 68.89 & 11.88 & 2097.9 & 27.58 & 28.58 \\
\hline & 72.22 & 11.83 & 2350.0 & 26.03 & 27.28 \\
\hline \multirow[t]{19}{*}{ Jefferson } & 21.83 & 11.08 & 804.7 & 13.89 & \\
\hline & 28.56 & 11.11 & 911.4 & 19.80 & 20.13 \\
\hline & 23.72 & 11.42 & 417.6 & 31.79 & 32.42 \\
\hline & 42.50 & 11.53 & 1219.2 & 26.06 & 26.77 \\
\hline & 69.72 & 11.53 & 2212.8 & 26.67 & 27.94 \\
\hline & 63.33 & 11.46 & 2171.7 & 24.23 & 25.41 \\
\hline & 44.72 & 11.10 & 917.4 & 37.91 & 38.92 \\
\hline & 66.67 & 11.71 & 2202.2 & 25.31 & 26.54 \\
\hline & 39.17 & 11.58 & 1219.2 & 23.20 & 23.86 \\
\hline & 40.83 & 11.58 & 1219.2 & 24.61 & 25.29 \\
\hline & 71.67 & 11.58 & 2177.8 & 27.98 & 29.32 \\
\hline & 75.56 & 11.56 & 2280.5 & 28.44 & 29.79 \\
\hline & 38.89 & 11.60 & 1100.3 & 25.51 & 26.23 \\
\hline & 53.33 & 11.56 & 2261.6 & 18.72 & 19.68 \\
\hline & 34.28 & 11.69 & 1036.3 & 22.45 & 23.13 \\
\hline & 33.89 & 11.67 & 1103.4 & 20.71 & 21.34 \\
\hline & 29.72 & 11.61 & 1127.8 & 16.51 & 17.05 \\
\hline & 74.72 & 11.69 & 2170.2 & 29.46 & 30.85 \\
\hline & 64.44 & 11.53 & 2234.2 & 24.01 & 25.18 \\
\hline Juniata & 58.89 & 10.91 & 2659.4 & 18.25 & 19.15 \\
\hline Lackawanna & 40.00 & 10.14 & 1648.4 & 18.46 & 19.20 \\
\hline \multirow[t]{2}{*}{ Lawrence } & 60.00 & 11.04 & 1453.9 & 34.39 & 35.24 \\
\hline & 47.78 & 11.08 & 1478.3 & 25.35 & 26.01 \\
\hline \multirow[t]{2}{*}{ Luzerne } & 30.00 & 10.49 & 1118.6 & 17.93 & 18.48 \\
\hline & 24.44 & 10.56 & 1402.1 & 10.13 & 10.48 \\
\hline
\end{tabular}




\begin{tabular}{|c|c|c|c|c|c|}
\hline County & $\begin{array}{r}\text { BHT } \\
\left({ }^{\circ} \mathrm{C}\right)\end{array}$ & $\begin{array}{l}\text { Tgw } \\
\left({ }^{\circ} \mathrm{C}\right)^{a}\end{array}$ & $\begin{array}{c}\text { Depth } \\
(\mathrm{m})\end{array}$ & $d T / d z$ & $\mathrm{dT} / \mathrm{dz} \mathrm{z}^{\mathrm{b}}$ \\
\hline \multirow[t]{8}{*}{ Lycoming } & 55.56 & 10.96 & 2024.5 & 22.36 & \\
\hline & 32.22 & 10.63 & 1187.2 & 18.67 & 19.23 \\
\hline & 61.67 & 11.08 & 2407.9 & 21.28 & 22.32 \\
\hline & 58.89 & 10.99 & 2202.8 & 22.05 & 23.13 \\
\hline & 57.89 & 11.06 & 1813.6 & 26.27 & \\
\hline & 59.17 & 11.03 & 2098.5 & 23.28 & 24.14 \\
\hline & 81.11 & 10.77 & 2474.4 & 28.78 & 29.45 \\
\hline & 54.44 & 11.13 & 2197.6 & 19.99 & 20.99 \\
\hline \multirow[t]{14}{*}{ McKean } & 48.06 & 10.72 & 1264.9 & 30.24 & 31.02 \\
\hline & 75.28 & 10.74 & 3618.0 & 17.99 & 19.04 \\
\hline & 47.78 & 10.73 & 1399.0 & 27.07 & 27.77 \\
\hline & 50.56 & 10.79 & 1720.6 & 23.53 & 24.42 \\
\hline & 62.22 & 10.89 & 2002.5 & 26.03 & 26.98 \\
\hline & 60.00 & 10.83 & 1551.4 & 32.33 & 33.51 \\
\hline & 50.00 & 10.71 & 1438.4 & 27.91 & 28.62 \\
\hline & 10.11 & 10.67 & 1173.5 & -0.49 & -0.31 \\
\hline & 42.78 & 10.66 & 1140.0 & 28.95 & 29.72 \\
\hline & 47.78 & 10.78 & 1659.6 & 22.71 & 23.59 \\
\hline & 40.00 & 10.67 & 1219.5 & 24.67 & 25.34 \\
\hline & 55.56 & 10.86 & 2068.1 & 21.94 & 22.76 \\
\hline & 43.89 & 10.83 & 1492.6 & 22.61 & 23.21 \\
\hline & 24.06 & 10.79 & 585.2 & 23.91 & 24.34 \\
\hline \multirow[t]{11}{*}{ Mercer } & 40.56 & 11.03 & 1537.7 & 19.59 & 20.13 \\
\hline & 43.33 & 11.04 & 1560.6 & 21.11 & 21.96 \\
\hline & 50.00 & 10.96 & 1882.4 & 21.07 & 21.88 \\
\hline & 43.33 & 10.97 & 1618.5 & 20.38 & 21.20 \\
\hline & 35.00 & 11.03 & 1460.6 & 16.86 & \\
\hline & 47.22 & 10.89 & 1661.2 & 22.28 & 23.15 \\
\hline & 40.28 & 10.91 & 1713.9 & 17.45 & 18.17 \\
\hline & 43.33 & 10.94 & 1749.6 & 18.84 & 19.60 \\
\hline & 43.50 & 10.92 & 1757.5 & 18.87 & 19.62 \\
\hline & 46.11 & 10.94 & 1539.2 & 23.31 & 24.23 \\
\hline & 64.44 & 10.92 & 2784.7 & 19.44 & 20.61 \\
\hline
\end{tabular}




\begin{tabular}{|c|c|c|c|c|c|}
\hline County & $\begin{array}{l}\text { BHT } \\
\left({ }^{\circ} \mathrm{C}\right)\end{array}$ & $\begin{array}{l}\text { Tgw } \\
\left({ }^{\circ} \mathrm{C}\right)^{a}\end{array}$ & $\begin{array}{c}\text { Depth } \\
(\mathrm{m})\end{array}$ & $d T / d z$ & $\mathrm{dT} / \mathrm{dz} \mathrm{b}^{\mathrm{b}}$ \\
\hline & 40.56 & 11.02 & 1612.1 & 18.67 & 19.44 \\
\hline Pike & 103.89 & 10.89 & 4239.8 & 22.09 & 23.33 \\
\hline \multirow[t]{16}{*}{ Potter } & 56.67 & 11.00 & 1920.2 & 24.17 & 25.06 \\
\hline & 60.83 & 11.06 & 1941.6 & 26.05 & 27.00 \\
\hline & 46.67 & 10.79 & 1740.1 & 20.99 & 221.80 \\
\hline & 46.94 & 11.04 & 1539.2 & 23.79 & \\
\hline & 60.00 & 10.98 & 1862.3 & 26.76 & 27.74 \\
\hline & 53.33 & 10.89 & 1877.6 & 22.98 & 23.85 \\
\hline & 58.33 & 10.93 & 2363.7 & 20.32 & 21.32 \\
\hline & 55.00 & 11.06 & 2133.0 & 20.90 & 21.69 \\
\hline & 59.44 & 11.06 & 2044.6 & 24.02 & 24.91 \\
\hline & 52.22 & 10.83 & 1566.7 & 26.94 & 27.96 \\
\hline & 47.78 & 10.81 & 1633.7 & 23.06 & 23.95 \\
\hline & 54.44 & 10.81 & 1600.2 & 27.80 & 28.84 \\
\hline & 47.22 & 10.78 & 1608.7 & 23.09 & 23.99 \\
\hline & 46.11 & 10.78 & 1565.1 & 23.02 & 23.92 \\
\hline & 40.56 & 10.78 & 1575.8 & 19.27 & 20.06 \\
\hline & 55.00 & 11.06 & 2088.5 & 21.35 & 22.15 \\
\hline \multirow[t]{13}{*}{ Somerset } & 77.00 & 12.00 & 2776.7 & 23.67 & 25.07 \\
\hline & 71.67 & 13.00 & 2407.9 & 24.68 & \\
\hline & 142.78 & 12.94 & 6521.0 & 19.94 & 20.60 \\
\hline & 62.78 & 12.83 & 2656.3 & 19.02 & \\
\hline & 64.44 & 12.58 & 2612.7 & 20.08 & \\
\hline & 43.33 & 12.67 & 1371.0 & 22.89 & 23.54 \\
\hline & 49.44 & 12.47 & 1959.0 & 19.16 & 19.93 \\
\hline & 72.22 & 12.50 & 2608.5 & 23.17 & 24.29 \\
\hline & 70.00 & 12.66 & 2255.5 & 25.77 & 27.03 \\
\hline & 51.11 & 12.64 & 2407.9 & 16.18 & \\
\hline & 38.89 & 12.44 & 1493.5 & 18.07 & 18.61 \\
\hline & 85.72 & 12.52 & 2743.2 & 26.98 & 28.56 \\
\hline & 76.11 & 12.39 & 2802.0 & 22.99 & 24.36 \\
\hline \multirow[t]{2}{*}{ Sullivan } & 77.78 & 10.52 & 2853.8 & 23.82 & \\
\hline & 60.83 & 10.52 & 2192.7 & 23.27 & \\
\hline
\end{tabular}




\begin{tabular}{|c|c|c|c|c|c|}
\hline County & $\begin{array}{l}\text { BHT } \\
\left({ }^{\circ} \mathrm{C}\right)\end{array}$ & $\begin{array}{l}\text { Tgw } \\
\left({ }^{\circ} \mathrm{C}\right)^{a}\end{array}$ & $\begin{array}{c}\text { Depth } \\
(\mathrm{m})\end{array}$ & $\mathrm{dT} / \mathrm{dz}$ & $d T / d z^{b}$ \\
\hline Susquehanna & 60.00 & 9.89 & 2601.2 & 19.49 & 20.43 \\
\hline \multirow[t]{7}{*}{ Tioga } & 65.56 & 10.92 & 1808.4 & 30.73 & 31.84 \\
\hline & 53.06 & 10.89 & 1661.2 & 25.86 & 26.83 \\
\hline & 79.44 & 10.92 & 3138.5 & 22.05 & 23.33 \\
\hline & 38.33 & 10.80 & 1387.8 & 20.29 & 20.85 \\
\hline & 52.22 & 10.81 & 1584.0 & 26.66 & 27.66 \\
\hline & 52.22 & 10.75 & 1681.0 & 25.13 & 26.08 \\
\hline & 70.00 & 10.94 & 2771.2 & 21.55 & 22.82 \\
\hline \multirow[t]{12}{*}{ Venango } & 48.89 & 10.89 & 1845.6 & 20.94 & 21.74 \\
\hline & 26.17 & 10.91 & 634.0 & 25.29 & 25.72 \\
\hline & 30.00 & 10.91 & 760.2 & 26.16 & 26.57 \\
\hline & 47.78 & 10.94 & 1984.2 & 18.85 & 19.59 \\
\hline & 45.42 & 10.94 & 2002.8 & 17.48 & 18.17 \\
\hline & 53.3 & 10.98 & 2033.6 & 21.14 & 21.94 \\
\hline & 45.56 & 10.96 & 1935.5 & 18.16 & 18.88 \\
\hline & 48.89 & 10.96 & 2048.6 & 18.80 & 19.52 \\
\hline & 21.11 & 10.89 & 312.4 & 36.26 & 37.01 \\
\hline & 16.67 & 10.86 & 211.7 & 32.07 & 32.07 \\
\hline & 30.00 & 10.89 & 659.3 & 30.39 & \\
\hline & 16.67 & 10.79 & 290.2 & 22.63 & \\
\hline \multirow[t]{6}{*}{ Warren } & 40.56 & 10.73 & 1418.5 & 21.56 & 22.14 \\
\hline & 41.67 & 10.65 & 1209.1 & 26.32 & 27.02 \\
\hline & 48.06 & 10.78 & 1770.9 & 21.42 & \\
\hline & 44.44 & 10.78 & 1837.3 & 18.63 & \\
\hline & 63.89 & 10.63 & 2478.0 & 25.84 & 26.05 \\
\hline & 43.33 & 10.74 & 1732.2 & 19.15 & 19.91 \\
\hline \multirow[t]{7}{*}{ Washington } & 73.06 & 11.97 & 2475.0 & 24.99 & 26.18 \\
\hline & 80.56 & 11.97 & 2329.9 & 29.83 & 31.23 \\
\hline & 25.28 & 12.11 & 807.7 & 16.94 & 17.27 \\
\hline & 73.33 & 12.06 & 2590.8 & 23.93 & 25.08 \\
\hline & 17.50 & 11.97 & 723.9 & 7.97 & \\
\hline & 33.33 & 12.17 & 1216.2 & 17.85 & 18.41 \\
\hline & 39.44 & 12.00 & 1338.1 & 20.99 & 21.59 \\
\hline
\end{tabular}




\begin{tabular}{|c|c|c|c|c|c|}
\hline County & $\begin{array}{r}\mathrm{BHT} \\
\left({ }^{\circ} \mathrm{C}\right)\end{array}$ & $\begin{array}{l}\mathrm{T}_{\mathrm{gw}} \\
\left({ }^{\circ} \mathrm{C}\right)^{\mathrm{a}}\end{array}$ & $\begin{array}{l}\text { Depth } \\
\text { (m) }\end{array}$ & $\mathrm{dT} / \mathrm{dz}$ & $\mathrm{dT} / \mathrm{dz} \mathrm{b}^{\mathrm{b}}$ \\
\hline & 50.00 & 12.36 & 2004.1 & 19.07 & \\
\hline & 26.67 & 12.13 & 890.0 & 16.91 & \\
\hline & 26.83 & 12.11 & 813.5 & 18.80 & 19.14 \\
\hline & 50.56 & 12.16 & 1796.8 & 21.74 & \\
\hline \multirow[t]{3}{*}{ Wayne } & 73.89 & 10.13 & 3733.8 & 17.22 & 18.21 \\
\hline & 32.78 & 10.21 & 1511.8 & 15.24 & 15.68 \\
\hline & 32.50 & 10.17 & 1521.0 & 14.98 & 15.42 \\
\hline \multirow[t]{16}{*}{ Wes tmorel and } & 23.50 & 12.00 & 895.5 & 13.29 & 13.57 \\
\hline & 60.00 & 12.13 & 2225.0 & 21.81 & 22.91 \\
\hline & 73.89 & 12.44 & 2274.1 & 27.39 & 28.70 \\
\hline & 66.11 & 12.76 & 2414.0 & 22.39 & 23.49 \\
\hline & 72.22 & 12.47 & 2255.5 & 26.85 & 18.15 \\
\hline & 63.33 & 12.42 & 2171.7 & 23.78 & 24.96 \\
\hline & 60.67 & 12.33 & 2260.7 & 21.67 & 22.76 \\
\hline & 46.39 & 12.25 & 1386.8 & 25.17 & 25.85 \\
\hline & 24.83 & 12.28 & 640.1 & 20.60 & 21.00 \\
\hline & 38.89 & 12.44 & 1097.3 & 24.79 & \\
\hline & 66.67 & 12.37 & 2514.6 & 21.86 & 22.93 \\
\hline & 70.56 & 12.50 & 2340.9 & 25.13 & 26.35 \\
\hline & 84.72 & 12.47 & 2356.9 & 31.04 & 32.50 \\
\hline & 31.11 & 12.08 & 1120.1 & 17.46 & 18.03 \\
\hline & 68.17 & 12.75 & 2539.3 & 22.09 & 23.18 \\
\hline & 68.89 & 12.65 & 2444.5 & 23.30 & 24.44 \\
\hline Wyoming & 46.11 & 10.08 & 1243.0 & 29.72 & 30.48 \\
\hline \multirow[t]{2}{*}{ Maryland } & 34.44 & 11.76 & 1380.7 & 16.80 & \\
\hline & 62.78 & 11.92 & 2167.1 & 23.80 & \\
\hline \multirow[t]{2}{*}{ West Virginia } & 115.00 & 13.39 & 5032.9 & 20.31 & \\
\hline & 78.89 & 11.90 & 3166.0 & 21.36 & \\
\hline
\end{tabular}


APPENDIX B, (cont)

a Ground water temperature at depth of $30.5 \mathrm{~m}$.

b Geothermal gradient correction for the effects of drilling.

Time Between Drilling Completion and Logging

\begin{tabular}{|c|c|}
\hline \multicolumn{2}{|c|}{ Depth (m) } \\
\hline $\begin{array}{r}0 \\
152.4 \\
304.8 \\
914.4 \\
1524.0 \\
2133.6\end{array}$ & $\begin{array}{r}152.4 \\
304.8 \\
914.4 \\
1524.0 \\
2133.6 \\
2743.2\end{array}$ \\
\hline
\end{tabular}

\begin{tabular}{ccc}
$0-1$ day & & 2 days \\
\cline { 1 - 1 }-1 & & 0 \\
0 & & 0 \\
1 & & 0 \\
2 & & 1 \\
3 & 2 \\
4 & & 2 \\
5 & & 3
\end{tabular}

C Borehole logged three or more days after completion of drilling. No temperature correction was applied. 


\section{APPENDIX C \\ DEPTH/TEMPERATURE RECORD FROM WELL 3236 , WASHINGTON COUNTY, OHIO}




\begin{tabular}{|c|c|c|c|}
\hline \multicolumn{2}{|c|}{ DEPTH } & \multicolumn{2}{|c|}{ TEMPERATURE } \\
\hline $\begin{array}{c}\text { Observed } \\
(\mathrm{m})\end{array}$ & $\begin{array}{l}\text { Topography } \\
\text { Corrected } \\
\text { (m) }\end{array}$ & $\begin{array}{c}\text { Observed } \\
\left({ }^{\circ} \mathrm{C}\right)\end{array}$ & $\begin{array}{c}\text { Climate } \\
\text { Corrected } \\
\left({ }^{\circ} \mathrm{C}\right)\end{array}$ \\
\hline 15.2 & & 11.92 & \\
\hline 30.5 & & 12.12 & \\
\hline 45.7 & & 12.35 & \\
\hline 61.0 & & 12.57 & \\
\hline 76.2 & & 12.85 & \\
\hline 91.4 & 76.2 & 13.08 & 13.42 \\
\hline 106.7 & & 13.33 & 13.71 \\
\hline 121.9 & 103.6 & 13.60 & 14.04 \\
\hline 137.2 & & 13.88 & 14.37 \\
\hline 152.4 & 134.1 & 14.18 & 14.73 \\
\hline 167.6 & & 14.52 & 15.12 \\
\hline 182.9 & 161.5 & 14.86 & 15.52 \\
\hline 198.1 & & 15.21 & 15.94 \\
\hline 213.4 & 192.0 & 15.42 & 16.21 \\
\hline 228.6 & & 15.53 & 16.38 \\
\hline 243.8 & 219.5 & 15.82 & 16.72 \\
\hline 259.1 & & 16.22 & 17.18 \\
\hline 274.3 & 249.9 & 16.64 & 17.65 \\
\hline 289.6 & & 16.95 & 18.01 \\
\hline 304.8 & 280.4 & 17.24 & 18.35 \\
\hline 320.0 & & 17.49 & 18.66 \\
\hline 335.3 & 307.8 & 17.77 & 19.00 \\
\hline 350.5 & & 17.99 & 19.27 \\
\hline 365.8 & 338.3 & 18.25 & 19.59 \\
\hline 381.0 & & 18.51 & 19.87 \\
\hline 396.2 & 368.8 & 18.73 & 20.15 \\
\hline 411.5 & & 18.90 & 20.37 \\
\hline 426.7 & 399.3 & 19.06 & 20.58 \\
\hline 442.0 & & 19.23 & 20.81 \\
\hline 457.22 & 426.7 & 19.49 & 21.12 \\
\hline 472.4 & & 19.79 & 21.43 \\
\hline 487.3 & 457.2 & 20.11 & 21.81 \\
\hline
\end{tabular}




\begin{tabular}{|c|c|c|c|}
\hline \multicolumn{2}{|c|}{ DEPTH } & \multicolumn{2}{|c|}{ TEMPERATURE } \\
\hline $\begin{array}{c}\text { Observed } \\
(\mathrm{m})\end{array}$ & $\begin{array}{l}\text { Topography } \\
\text { Corrected } \\
\text { (m) }\end{array}$ & $\begin{array}{c}\text { Observed } \\
\left({ }^{\circ} \mathrm{C}\right)\end{array}$ & $\begin{array}{c}\text { Climate } \\
\text { Corrected } \\
\left({ }^{\circ} \mathrm{C}\right)\end{array}$ \\
\hline 502.9 & & 20.49 & 22.24 \\
\hline 518.2 & 487.7 & 20.89 & 22.69 \\
\hline 533.4 & & 21.32 & 23.18 \\
\hline 548.6 & 518.2 & 21.79 & 23.70 \\
\hline 563.9 & & 21.88 & 23.78 \\
\hline
\end{tabular}




\section{APPENDIX D \\ DEPTH/TEMPERATURE RECORD FROM BARBERTON WELL, SUMMIT COUNTY, OHIO}




\begin{tabular}{|c|}
\hline $\begin{array}{c}\text { Depth } \\
\text { (m) }\end{array}$ \\
\hline 0 \\
\hline 50 \\
\hline 75 \\
\hline 100 \\
\hline 105 \\
\hline 110 \\
\hline 115 \\
\hline 120 \\
\hline 124 \\
\hline 130 \\
\hline 135 \\
\hline 140 \\
\hline 145 \\
\hline 150 \\
\hline 180 \\
\hline 210 \\
\hline 240 \\
\hline 270 \\
\hline 300 \\
\hline 330 \\
\hline 360 \\
\hline 390 \\
\hline 420 \\
\hline 450 \\
\hline 480 \\
\hline
\end{tabular}
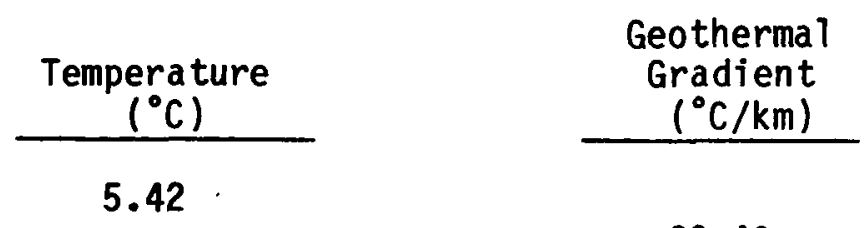

9.83

12.79

12.47

12.61

12.62

12.65

12.69

88.40

118.40

$-12.80$

28.00

2.00

6.00

12.79

12.87

13.00

13.24

13.06

13.50

14.40

8.00

20.00

16.00

26.00

48.00

$-36.00$

88.00

30.00

24.33

15.13

23.00

15.82

16.39

19.00

16.33

16.88

27.00

17.69

24.67

18.43

19.33

30.00

31.33

20.27

12.00

20.63

18.67

21.19

32.00 


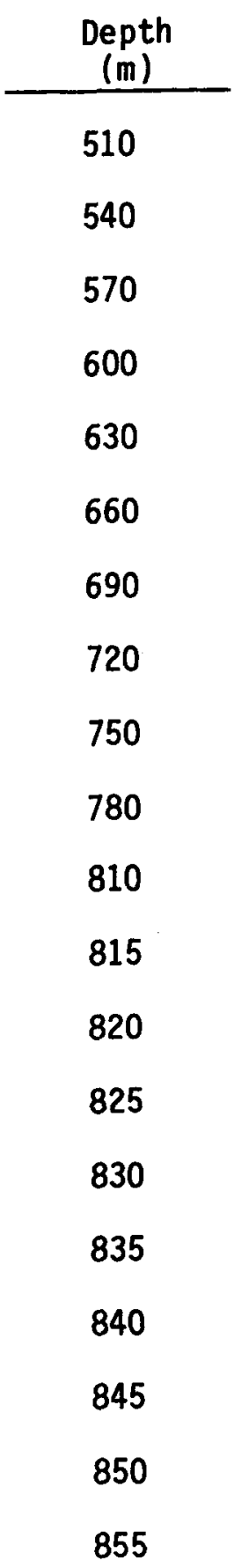
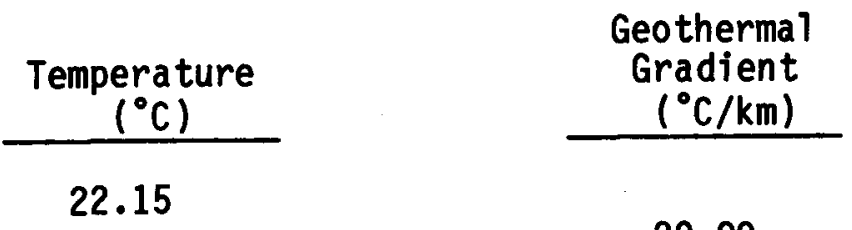

23.02

23.86

25.09

26.51

27.33

28.01

28.01

29.08

29.76

31.17

31.46

31.85

32.14

32.66

32.95

33.02

33.05

33.12

33.19

29.00

28.00

41.00

47.33

27.33

22.67

23.33

12.33

22.67

47.00

58.00

78.00

58.00

104.00

58.00

14.00

6.00

14.00

14.00 


\section{APPENDIX E \\ DEPTH/TEMPERATURE RECORD FROM MORRISON WELL, VENANGO COUNTY, PENNSYLVANIA}




\begin{tabular}{|c|c|c|c|c|c|c|c|c|}
\hline & & & & & \\
\hline $\begin{array}{c}\text { Ob- } \\
\text { served } \\
\text { (m) } \\
\end{array}$ & $\begin{array}{c}\text { Topog. } \\
\text { (m) }\end{array}$ & $\begin{array}{c}\text { ob- } \\
\text { served } \\
\left({ }^{\circ} \mathrm{C}\right) \\
\end{array}$ & $\begin{array}{l}\text { River } \\
\left({ }^{\circ} \mathrm{C}\right)\end{array}$ & $\begin{array}{l}\text { Climate } \\
\left({ }^{\circ} \mathrm{C}\right)\end{array}$ & $\begin{array}{l}\text { Ob- } \\
\text { served } \\
\left.{ }^{\circ} \mathrm{C} / \mathrm{km}\right) \\
\end{array}$ & $\begin{array}{l}\text { River } \\
\text { Corr. } \\
\left({ }^{\circ} \mathrm{C} / \mathrm{km}\right) \\
\end{array}$ & $\begin{array}{l}\text { River \& } \\
\text { Climate } \\
\text { Corr. } \\
\left.0^{\circ} \mathrm{C} / \mathrm{km}\right) \\
\end{array}$ & $\begin{array}{l}\text { RTver, } \\
\text { Climate, } \\
\text { Topogg. } \\
1{ }^{\circ} \mathrm{C} / \mathrm{km}\end{array}$ \\
\hline 10.00 & 0.86 & 5.23 & 5.23 & 5.02 & & & & \\
\hline 20.00 & 10.11 & 5.37 & 5.68 & 5.28 & & 44.00 & 26.00 & \\
\hline 30.00 & 19.36 & 6.18 & 6.20 & 5.67 & & & 9.00 & \\
\hline 40.00 & 28.63 & 6.38 & 6.40 & 5.81 & 31.00 & .00 & 3 & 34.48 \\
\hline 50.00 & 37.91 & 6.69 & 6.72 & 6.13 & 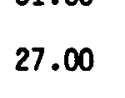 & 2.00 & 33 & 5.48 \\
\hline & .2 & 0.90 & 99 & & 14.00 & 15.00 & 24.00 & 25.72 \\
\hline 70.00 & 56.54 & 7.10 & .14 & 6.70 & 20.00 & 20.00 & 31.00 & 33.19 \\
\hline 80.00 & 65.88 & 7.62 & & 47 & 00 & 3.00 & 6.00 & 9.04 \\
\hline 20.00 & 84.6 & 7.9 & & & 33.00 & 34.00 & 46.00 & 48.94 \\
\hline 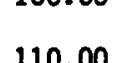 & 4.08 & & & & 19.00 & 20.00 & 32.00 & 33.97 \\
\hline 110.00 & 4.08 & 019 & & & 28.00 & 28.00 & 38.00 & 40.21 \\
\hline 120.0 & 113.01 & $0.4<$ & 8 & & 14.00 & 15.00 & 25.00 & 26.37 \\
\hline 140.00 & 122.51 & 8.81 & 8.90 & 9.22 & .00 & 5.00 & 34.00 & 35.79 \\
\hline 150.00 & 132.04 & 9.13 & 9.23 & 9.63 & 2.00 & 34.00 & 41.00 & 43.02 \\
\hline 160.00 & 141.60 & 9.35 & 9.46 & 9.92 & 22.00 & 23.00 & 29.00 & 30.33 \\
\hline 170.00 & 151.17 & 9.53 & 9.65 & 10.17 & & & & 2 \\
\hline 180.00 & 160.77 & 9.68 & 9.81 & 10.38 & $n$ & 0 & 00 & .88 \\
\hline 190.00 & 170.39 & 9.89 & 10.03 & 10.64 & & 22.00 & 26.00 & 27.03 \\
\hline 200.00 & 180.03 & 10.11 & 10.26 & 10.91 & & 3.00 & 7.000 & 28.01 \\
\hline 210.00 & 189.67 & 10.33 & 10.49 & 11.18 & & 0 & 2700 & 28.01 \\
\hline 220.00 & 199.36 & 10.51 & 10.68 & 11.40 & & 19.00 & 2 & 22.70 \\
\hline 230.00 & 209.06 & 10.77 & 10.95 & 11.71 & 25.00 & 27.00 & 30.00 & .93 \\
\hline 240.00 & 218.76 & 11.02 & 11.22 & 12.01 & 20.00 & 21.00 & 24.00 & 24.67 \\
\hline 250.00 & 228.49 & 11.22 & 11.43 & 12.25 & 29.00 & 30.00 & 33.00 & 33.88 \\
\hline 260.0 & 238.2 & 11.51 & 11.73 & 12.58 & 18.00 & 19.00 & 22.00 & 22.56 \\
\hline & 98 & 11.69 & 11.92 & 12.80 & 18.00 & 19.00 & 22.00 & 22.54 \\
\hline 280.00 & 257.74 & 11.87 & 12.11 & 13.02 & 78.00 & 81.00 & 84.00 & 85.89 \\
\hline 290.00 & 267. & 12. & 12.92 & 13.86 & 76.00 & 79.00 & 82.00 & 83.76 \\
\hline $300 \mathrm{~m}$ & 277 & 1349 & 1371 & 14.68 & 12.00 & 12.00 & 14.00 & 14.31 \\
\hline 305.00 & 282.20 & 13.47 & 13.77 & 14.75 & & & & \\
\hline
\end{tabular}




\section{APPENDIX F}

DEPTH/TEMPERATURE RECORD FROM BOWSER WELL, CLARION COUNTY, PENNSYLVANIA 


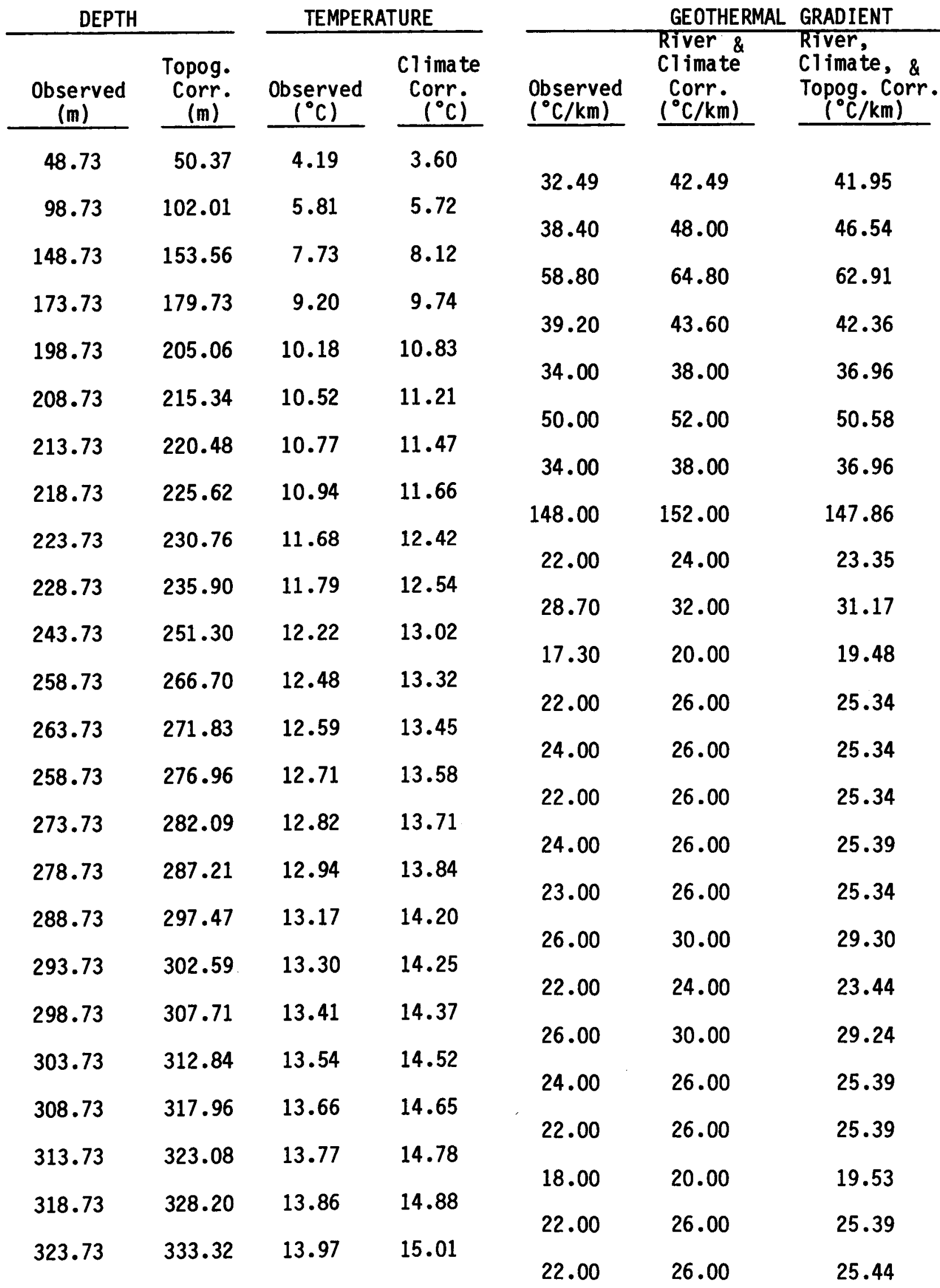




\begin{tabular}{|c|c|c|c|c|c|c|}
\hline \multicolumn{2}{|c|}{ DEPTH } & \multicolumn{2}{|c|}{ TEMPERATURE } & \multicolumn{2}{|c|}{$\begin{array}{l}\text { GEOTHERMAL } \\
\text { River \& }\end{array}$} & \multirow{2}{*}{$\begin{array}{l}\text { GRADIENT } \\
\text { River, } \\
\text { Climate, \& } \\
\text { Topog. Corr } \\
\left({ }^{\circ} \mathrm{C} / \mathrm{km}\right) \\
\end{array}$} \\
\hline $\begin{array}{c}\text { Observed } \\
\text { (m) }\end{array}$ & $\begin{array}{c}\text { Topog. } \\
\text { Corr. } \\
(\mathrm{m}) \\
\end{array}$ & $\begin{array}{l}\text { Observed } \\
\left({ }^{\circ} \mathrm{C}\right)\end{array}$ & $\begin{array}{c}\text { Climate } \\
\text { Corr. } \\
\left({ }^{\circ} \mathrm{C}\right) \\
\end{array}$ & $\begin{array}{l}\text { Observed } \\
\left({ }^{\circ} \mathrm{C} / \mathrm{km}\right) \\
\end{array}$ & $\begin{array}{l}\text { River } 8 \\
\text { Climate } \\
\text { Corr. } \\
\left({ }^{\circ} \mathrm{C} / \mathrm{km}\right) \\
\end{array}$ & \\
\hline 328.73 & 338.43 & 14.08 & 15.14 & $27 \quad 15$ & $20 \wedge 0$ & 0070 \\
\hline 333.83 & 343.65 & 14.22 & 15.29 & & & \\
\hline 338.73 & 348.67 & 14.30 & 15.39 & 10.00 & 20.70 & 19.92 \\
\hline 343.73 & 353.78 & 14.37 & 15.47 & 14.00 & 10.00 & 15.66 \\
\hline 348.73 & 358.89 & 14.51 & 15.63 & 30.00 & 34.00 & 33.20 \\
\hline 353.73 & 364.01 & 14.66 & 15.80 & 28.00 & 31.00 & 30.33 \\
\hline 363.73 & 374.23 & 14.94 & 16.11 & 27.00 & 30.00 & 29.35 \\
\hline 373.73 & 384.45 & 15.21 & 16.41 & 28.67 & 32.00 & 31.33 \\
\hline 388.73 & 399.77 & 15.64 & 16.89 & 30.00 & 34.00 & 33.29 \\
\hline 403.73 & 415.09 & 16.09 & 17.40 & 26.00 & 29.30 & 28.76 \\
\hline 418.73 & 430.39 & 16.48 & 17.84 & 27.50 & 31.00 & 30.39 \\
\hline 438.73 & 450.79 & 17.03 & 18.46 & 28.00 & 31.30 & 30.74 \\
\hline 453.73 & 466.08 & 17.45 & 18.93 & & & \\
\hline
\end{tabular}




\author{
APPENDIX G \\ THERMAL CONDUCTIVITY OF CORE SAMPLES \\ FROM WELLS IN WASHINGTON, NOBLE, \\ AND MORGAN COUNTIES, OHIO
}




\begin{tabular}{|c|c|c|c|c|}
\hline \multirow[t]{2}{*}{$\begin{array}{r}\text { Depth } \\
(\mathrm{m})\end{array}$} & Lithology & \multicolumn{2}{|c|}{$\begin{array}{c}\text { Thermal Conductivity } \\
\text { R(dry) K(wet) } \\
\text { (mcal } / \text { cmsec }^{\circ} \mathrm{C} \text { ) } \\
\end{array}$} & \multirow[t]{2}{*}{$\begin{array}{c}\text { Porosity } \\
(\%)\end{array}$} \\
\hline & We11 238 & hington & $y$, Ohio & \\
\hline 34.1 & Ls & 5.53 & 5.73 & 1.46 \\
\hline 108.6 & Ss & 5.95 & 7.95 & 8.54 \\
\hline 130.2 & Ss & 6.44 & 7.16 & 3.05 \\
\hline 169.5 & Sh & 2.80 & 2.88 & 5.36 \\
\hline 175.4 & Sh & 3.54 & 3.47 & 2.86 \\
\hline 192.9 & Sh & 4.22 & 4.22 & 2.07 \\
\hline 196.0 & Ss & 8.56 & 10.41 & 9.28 \\
\hline 196.7 & Sh & 3.53 & 3.52 & 3.34 \\
\hline $2-6.3$ & Ls & 5.11 & 5.22 & 0.58 \\
\hline 234.1 & sitst & 4.14 & 4.01 & 3.19 \\
\hline 250.6 & Ls & 7.18 & 7.69 & 1.04 \\
\hline
\end{tabular}

Well 2181, Washington County, Ohio

$\begin{array}{rlrrr}57.1 & \text { Ss } & 6.64 & 9.39 & 8.27 \\ 58.6 & \text { Ls } & 4.13 & 4.98 & 2.83 \\ 64.4 & \text { Ss } & 7.00 & 8.51 & 4.15 \\ 72.3 & \text { Mdst } & 6.44 & 6.88 & 2.09 \\ 152.7 & \text { Ss } & 7.85 & 10.14 & 3.40 \\ 154.2 & \text { Sh } & 3.78 & 3.83 & 3.68 \\ 158.4 & \text { Sh } & 4.51 & 4.74 & 1.86 \\ 165.7 & \text { S1 tst } & 3.82 & 4.10 & 2.48 \\ 165.8 & \text { S1 tst } & 3.75 & 4.09 & 3.46 \\ 172.9 & \text { Ss } & 6.98 & 8.19 & 2.71 \\ 175.8 & \text { Sh } & 4.96 & 5.19 & --- \\ 217.3 & \text { Coal } & 0.93 & 0.98 & 3.53 \\ 217.3 & \text { Coal } & 1.13 & 1.19 & 2.58 \\ 217.3 & \text { Coal } & 0.77 & 0.812 & 3.51 \\ 217.5 & \text { Mdst } & 4.82 & 4.93 & 2.78 \\ 227.0 & \text { Sh } & 3.48 & 3.53 & ---\end{array}$




\begin{tabular}{|c|c|c|c|c|}
\hline \multirow[t]{2}{*}{$\begin{array}{r}\text { Depth } \\
(\mathrm{m})\end{array}$} & Lithology & \multicolumn{2}{|c|}{$\begin{array}{l}\text { Thermal Conductivity } \\
\text { R(dry) K(wet) } \\
\left.\text { (mcal } / \mathrm{cmsec}^{\circ} \mathrm{C}\right) \text {. }\end{array}$} & \multirow[t]{2}{*}{$\begin{array}{c}\text { Porosity } \\
(\%)\end{array}$} \\
\hline & \multicolumn{3}{|c|}{ Wel1 2387, Noble County, Ohio } & \\
\hline 106.2 & s1tst & 4.84 & 5.25 & $-\cdots$ \\
\hline \multirow[t]{2}{*}{129.4} & s1tst & 5.93 & 6.29 & 1.74 \\
\hline & \multicolumn{3}{|c|}{ Well 2176, Noble County, Ohio } & \\
\hline 53.6 & Ls & 7.11 & 7.36 & 1.94 \\
\hline 59.7 & Ls & 5.65 & 5.73 & 0.60 \\
\hline 89.3 & s1 tst & 5.00 & 6.01 & 6.00 \\
\hline 117.9 & Ss & 4.72 & 5.40 & 4.60 \\
\hline 127.3 & Mdst & 3.53 & 3.42 & 5.11 \\
\hline 139.3 & Ss & 7.81 & 10.29 & 10.65 \\
\hline 140.1 & Ss & 8.23 & 10.47 & 9.36 \\
\hline 152.7 & Ss & 7.81 & 9.85 & 11.36 \\
\hline 163.1 & Ss & 4.68 & 5.52 & 4.15 \\
\hline 164.9 & Mdst & 4.58 & 4.53 & -- \\
\hline 165.6 & sitst & 5.15 & 5.54 & 2.61 \\
\hline 171.7 & Ss & 8.05 & 10.20 & 8.68 \\
\hline 178.3 & Sh & 3.62 & 3.52 & 4.82 \\
\hline 184.4 & s1tst & 4.38 & 5.01 & 4.24 \\
\hline 194.1 & Sh & 4.06 & 4.16 & 3.62 \\
\hline 229.3 & Sh & 4.20 & 4.46 & 2.22 \\
\hline 229.3 & Sh & 4.31 & 4.53 & 2.57 \\
\hline 231.2 & Ss & 8.00 & 9.02 & 2.82 \\
\hline
\end{tabular}

Well 2177, Noble County, Ohio

$\begin{array}{rlrrr}100.0 & \text { Sh } & 4.34 & 4.82 & 3.77 \\ 122.2 & \text { Ss } & 7.06 & 9.39 & 10.82 \\ 163.4 & \text { Ss } & 5.88 & 7.23 & 3.87 \\ 183.8 & \text { S1 tst } & 5.96 & 6.28 & 2.88 \\ 219.7 & \text { Ss } & 9.53 & 11.70 & 20.24\end{array}$




Depth
$(\mathrm{m})$$\quad$ Lithology $\quad \begin{aligned} & \text { K(dry) } \\ & \left.\text { (mcal } / \mathrm{cmsec}^{\circ} \mathrm{C}\right)\end{aligned}$

Well 2178, Morgan County, Ohio

69.4
78.6
124.6
155.0
174.9
182.9
200.2
214.1
217.9
242.0
267.9

Sh

5.15

5.95

Sh

4.14

4.40

1.13

Sh

3.67

3.76

Ss

7.67

9.72

12.14

Ss

8.09

9.70

10.96

Mdst

4.30

4.32

3.97

S1 tst

6.20

6.36

1.84

S1 tst

4.77

4.83

3.31

Ss

7.04

8.11

2.82

Sh

4.60

4.68

2.51

S1tst

4.86

4.98

We11 2180, Morgan County, Ohio

70.7
85.6
93.6
104.1
168.2
187.7
200.6
222.4

Mdst

4.19

4.44

3.80

S1 tst

4.42

4.74

5.15

LS

5.54

5.50

2.33

Ss

8.30

9.24

2.72

S1tst

3.41

3.41

3.77

Sh

3.15

3.35

Sh

3.78

4.04

2.57

Sitst

6.02

6.08

4.42

Well 2182, southeastern Ohio

232.9
234.8
244.8
247.2
248.3
251.2

Sh

4.09

4.12

2.40

S1tst

4.33

4.38

2.42

Ss

9.25

11.05

10.76

Mdst

5.92

5.92

2.41

S1 tst

6.80

6.97

2.01

Mdst

6.12

6.24

2.82 


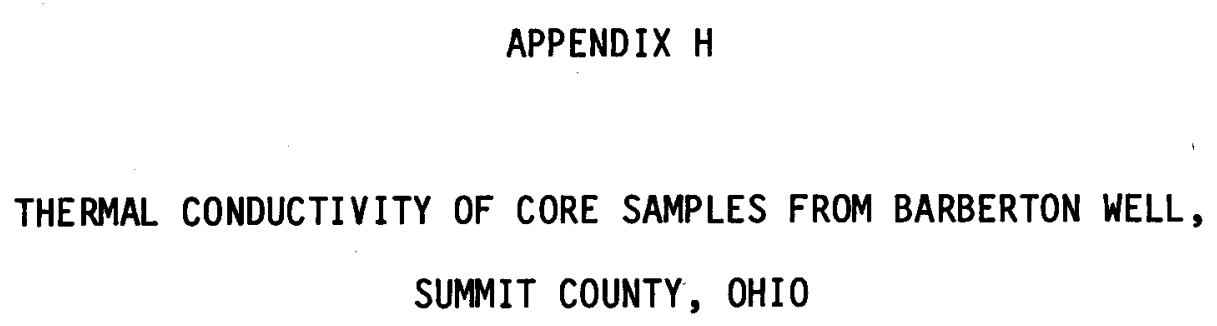

SUMMIT COUNTY, OHIO 


\begin{tabular}{|c|c|c|c|c|}
\hline $\begin{array}{r}\text { Depth } \\
(\mathrm{m})\end{array}$ & Lithology & $\begin{array}{r}\text { Therma } \\
\text { K(dry) } \\
\text { (mc } \\
\end{array}$ & $\begin{array}{l}\text { tivity } \\
\text { K(wet) } \\
\left.{ }^{\circ} \mathrm{C}\right)\end{array}$ & $\begin{array}{c}\text { Porosity } \\
(\%) \\
\end{array}$ \\
\hline 113.9 & Sh & 1.38 & --- & --- \\
\hline 117.4 & Sh & 3.00 & 4.43 & 1.36 \\
\hline 118.3 & Sh & 3.22 & 3.91 & 1.09 \\
\hline 121.1 & Sh & 2.25 & 2.93 & 1.74 \\
\hline 123.5 & Sh & 2.46 & 2.94 & 1.41 \\
\hline 126.9 & Sh & 2.63 & --- & -- \\
\hline 129.6 & Sh & 2.35 & -- & -- \\
\hline 132.7 & Sh & 2.83 & 3.14 & 1.99 \\
\hline 135.7 & Sh & 2.00 & --- & --- \\
\hline 138.8 & Sh & 1.37 & --- & --- \\
\hline 142.1 & Sh & 1.25 & --- & --- \\
\hline 147.6 & Sh & 1.64 & 3.40 & 1.26 \\
\hline 782.6 & Ls & 5.64 & 5.64 & 2.03 \\
\hline 786.9 & Ls & 5.45 & 5.55 & 21.45 \\
\hline 791.8 & Ls & 6.12 & 5.90 & .74 \\
\hline 796.7 & Ls & 5.24 & 6.74 & .69 \\
\hline 801.5 & Ls & 3.50 & 5.00 & .48 \\
\hline 806.1 & Ls & 5.30 & 7.10 & .78 \\
\hline 813.7 & Ls & 3.84 & 3.91 & 5.18 \\
\hline 816.2 & Ls & 4.89 & 4.73 & 1.91 \\
\hline 820.2 & Ls & 4.56 & 4.66 & 1.66 \\
\hline 825.9 & Ls & 5.46 & 5.87 & .95 \\
\hline 830.8 & Ls & 6.06 & 6.47 & .69 \\
\hline 835.7 & Ls & 5.67 & 6.02 & 2.17 \\
\hline 840.3 & Ls & 6.23 & 6.63 & 1.62 \\
\hline 846.4 & Ls & 5.33 & 5.46 & 1.11 \\
\hline 850.3 & Ls & 5.90 & 6.15 & 1.33 \\
\hline 855.2 & Ls & 5.81 & 6.21 & 1.42 \\
\hline
\end{tabular}




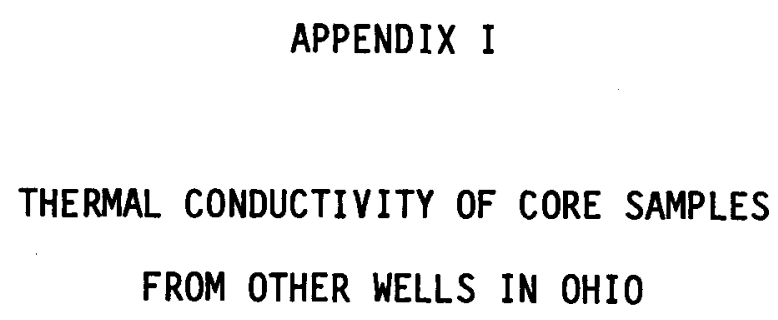


Thermal Conductivity

Depth

(m)

Lithology

$\underset{\left(\text { mcal } / \text { cmsec }^{\circ} \mathrm{C}\right)}{K(\text { wet })^{a}}$

Porosity

$(\%)$

Wilson well, Fayette County, Ohio

394.9

398.0

401.1

550.5

556.6

557.2

838.8

927.2

930.3

930.3

931.8

936.4

LS

5.21

7.01

1.90

LS

4.75

8.96

2.39

LS

4.32

5.06

1.32

Do 1

5.60

9.96

4.13

Do1

6.82

8.18

9.94

Dol

7.47

7.59

4.97

Sh

2.67

3.32

1.33

Ss

5.31

7.23

10.73

Ss

3.98

7.83

11.20

Ss

3.75

7.59

9.30

Ss

5.45

7.30

10.30

LS

7.84

10.24

5.082

Heston well, Morrow County, Ohio

1217.6

LS

8.45

9.16

5.48

1218.5

LS

7.01

8.17

6.72

1220.0

LS

8.53

9.72

8.08

1221.2

LS

6.82

9.03

2.24

1223.1

Ls

6.82

9.03

2.24

1223.1

LS

6.77

8.07

5.13

1224.6

Ls

7.21

8.92

6.10

1226.1

LS

6.05

8.20

3.58

1227.6

LS

8.24

9.42

3.29

1220.2

LS

8.46

28.76

2.95

1231.0

LS

7.16

7.22

5.02 


\section{Thermal Conductivity}

\begin{tabular}{|c|c|c|c|}
\hline$\underset{(m)}{\text { Depth }}$ & Lithology & $\underset{\left(\mathrm{mcal} / \mathrm{cmsec}^{\circ} \mathrm{C}\right)}{K(\text { wet })^{\mathrm{a}}}$ & $\begin{array}{l}\text { Porosity } \\
(\%)\end{array}$ \\
\hline
\end{tabular}

U. S. Gypsum wel1, Ottawa County, Ohio

$\begin{array}{rlrrr}37.9 & \text { Dol } & 12.58 & 13.49 & 4.84 \\ 46.1 & \text { Dol } & 8.84 & 11.92 & 5.62 \\ 51.5 & \text { Dol } & 9.13 & 10.55 & 9.06 \\ 61.1 & \text { Dol } & 12.27 & 13.17 & 5.88 \\ 68.6 & \text { Dol } & 12.02 & 12.80 & 3.56 \\ 76.3 & \text { Dol } & 10.04 & 12.26 & 10.33 \\ 82.6 & \text { Dol } & 10.50 & 12.832 & 7.86 \\ 99.1 & \text { Dol } & 10.37 & 12.90 & 9.74 \\ 107.1 & \text { Dol } & 9.17 & 9.70 & 9.89 \\ 113.5 & \text { Sh } & 2.55 & --- & --- \\ 114.1 & \text { Sh } & 2.60 & --- & -- \\ 129.3 & \text { Dol } & 10.77 & 12.27 & 5.64 \\ 137.6 & \text { Dol } & 10.68 & 11.60 & 3.58 \\ 143.0 & \text { Sh } & 2.56 & --- & 1.33\end{array}$

aseveral green shales disaggregated during the vacuum-saturation process. Another was destroyed during pressurized-conductivity measurement. Paraffin bindings did not keep these shales from being destroyed. 


\section{APPENDIX J}

THERMAL CONDUCTIVITY OF CORE SAMPLES

FROM THE WELLS IN CLARION AND

VENANGO COUNTIES, PENNSYLVANIA 


\begin{tabular}{|c|c|c|c|c|c|c|}
\hline \multirow[b]{2}{*}{$\begin{array}{l}\text { Depth } \\
\text { (m) }\end{array}$} & \multirow[b]{2}{*}{ Lithology } & \multirow[b]{2}{*}{$K($ dry $)$} & Thermal Conductivity & \multicolumn{2}{|c|}{ Porositya } & \multirow{2}{*}{$\begin{array}{l}\text { Sonic Velocityb } \\
(\mathrm{m} / \mathrm{sec})\end{array}$} \\
\hline & & & $\begin{array}{c}K(\text { wet }) \\
\text { Vacuum satur. } \\
\text { (mcal } / \mathrm{cmsec}^{\circ} \frac{16-\text { day atm. satur. }}{} \\
\end{array}$ & $\begin{array}{l}\text { Vacuum } \\
\text { satur. } \\
(x) \\
\end{array}$ & $\begin{array}{l}\text { 16-day atm. } \\
\text { satur. } \\
\text { (q) }\end{array}$ & \\
\hline & & & \multicolumn{2}{|c|}{ Bankson well, Venango County, Pennsylyania } & & \\
\hline 241.4 & Ss & 7.36 & 8.78 & 2.75 & & \\
\hline 244.4 & Ss & 9.38 & 10.49 & 5.98 & & \\
\hline 247.3 & Ss & 9.37 & 10.44 & 13.95 & & \\
\hline 250.0 & Ss & 6.48 & 7.24 & 13.95 & & \\
\hline 351.2 & Sh & 3.46 & --- & $\cdots$ & & \\
\hline 251.9 & Sh & 3.42 & -- & $-\cdots$ & & \\
\hline 286.7 & Ss & 8.342 & 9.28 & 8.67 & & \\
\hline 290.3 & Cgl & 9.50 & 11.27 & 10.65 & & \\
\hline
\end{tabular}

Marsh wel1, Venango County, Pennsylvania

\begin{tabular}{|c|c|c|c|c|c|c|c|}
\hline 258.9 & Ss & 8.77 & 10.24 & & 7.41 & & \\
\hline 287.1 & Ss & 8.44 & 9.39 & 9.55 & 2.78 & 3.42 & 4063.9 \\
\hline 293.8 & Ss & 6.94 & 8.35 & & 15.32 & & 4417.5 \\
\hline 298.1 & Ss & 9.24 & 10.40 & & 7.93 & & 4354.4 \\
\hline 299.3 & Ss & 7.99 & 10.07 & & 9.02 & & 4175.5 \\
\hline 301.1 & Ss & 5.78 & 8.49 & & 6.94 & & 4293.1 \\
\hline
\end{tabular}

Hazlett well, Yenango County, Pennsylvanfa

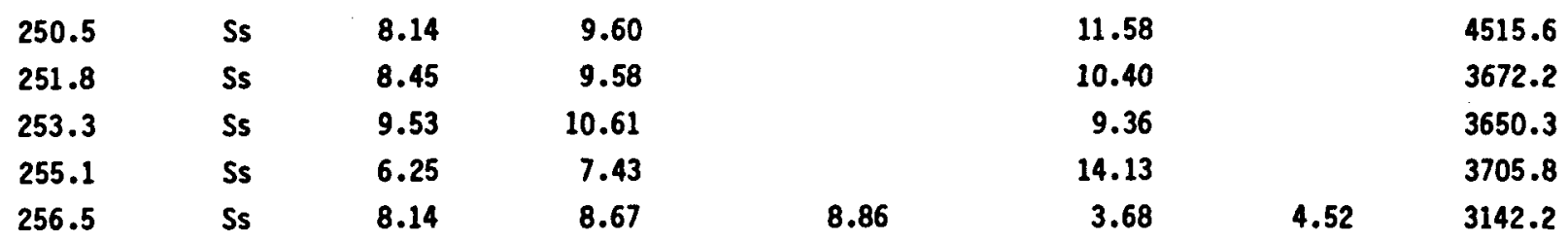

Reed well, Yenango County, Pennsylvania

$\begin{array}{llrrrr}226.3 & \text { Cg1 } & 11.58 & 11.79 & 4.39 & 4262.9 \\ 248.7 & \text { Sh } & 3.89 & 4.67 & 4.28 & 3907.8 \\ 263.9 & \text { Sh } & 4.30 & 5.25 & 4.18 & 4354.4 \\ 264.7 & \text { Sh } & 4.94 & 3.71 & 2.86 & 3907.8 \\ 267.9 & \text { Ss } & 6.25 & 7.35 & 4.58 & 4532.4\end{array}$




\begin{tabular}{|c|c|c|c|c|c|c|c|}
\hline \multirow[b]{2}{*}{$\begin{array}{c}\text { Depth } \\
\text { (m) }\end{array}$} & \multirow[b]{2}{*}{ Lithology } & \multirow[b]{2}{*}{ K(dry) } & \multicolumn{2}{|c|}{ Thermal Conductivity } & \multicolumn{2}{|c|}{ Porositya } & Sonic Velocityb \\
\hline & & & $\frac{\begin{array}{c}k(\text { wet }) \\
\text { Vacuum satur. }\end{array}}{(\mathrm{mca}) / \mathrm{cm}}$ & $\begin{array}{c}K \text { (wet) } \\
16-\text { day a atm. satur. } \\
e c^{\circ} \mathrm{C} \text { ) }\end{array}$ & $\begin{array}{c}\text { Vacuum } \\
\text { satur. } \\
(\%) \\
\end{array}$ & $\begin{array}{c}\text { 16-day atm. } \\
\text { satur. } \\
(\%) \\
\end{array}$ & $(\mathrm{m} / \mathrm{sec})$ \\
\hline \multicolumn{8}{|c|}{ Bowser well, Clarion County, Pennsylvania } \\
\hline 219.5 & Sh & 4.67 & 4.63 & $\cdots$ & 1.86 & 1.94 & 4063.9 \\
\hline 222.8 & Cgl & 11.14 & 12.99 & & 6.00 & & 4629.9 \\
\hline $224.1 \cdots$ & Sgl & 10.32 & 11.29 & & 6.40 & & 4493.4 \\
\hline 269.0 & Ss & 7.92 & 10.38 & & 7.83 & & 3825.8 \\
\hline 271.0 & Ss2 & 7.68 & 7.77 & 7.77 & 0.71 & 2.41 & 4313.2 \\
\hline 272.0 & Ss & 5.91 & 6.84 & & 4.99 & & 4594.9 \\
\hline 280.9 & Ss & 6.60 & 6.65 & -- & 2.26 &.- & 4063.9 \\
\hline 282.1 & Sitst & 7.57 & 8.03 & --- & 1.27 & 1.27 & 4701.2 \\
\hline 283.1 & s1tst & 5.36 & $\ldots$ & -- & 4.44 & --- & 4618.3 \\
\hline 285.1 & Sh & 3.85 & 3.83 & 3.37 & 3.20 & 4.69 & 4313.2 \\
\hline 286.2 & Sh & 3.48 & 3.52 & 3.48 & 1.99 & 3.92 & 4375.1 \\
\hline 287.4 & Ss & 7.32 & 9.27 & & 4.19 & & 4417.5 \\
\hline 288.8 & Ss & 6.59 & 7.58 & & 2.66 & & 4406.8 \\
\hline 290.0 & Ss & 6.85 & 8.23 & & 5.53 & & 4375.1 \\
\hline 291.4 & Ss & 5.51 & 6.40 & & 2.75 & & 4537.9 \\
\hline 293.2 & Ss & 5.32 & 5.76 & 5.88 & 1.77 & 2.97 & 4549.1 \\
\hline 294.4 & Ss & 6.37 & 7.00 & 7.20 & 2.09 & 3.34 & 4526.6 \\
\hline 296.3 & Ss & 6.58 & 7.86 & & 4.68 & & 4471.4 \\
\hline 308.3 & s1tst & 8.25 & 8.59 & 8.32 & 0.89 & 2.31 & 4375.1 \\
\hline 310.0 & Cg1 & 7.85 & 8.91 & -.- & 1.20 & 1.20 & 5080.1 \\
\hline 323.8 & Sh & 5.43 & 5.63 & 5.71 & 2.00 & 3.67 & 4629.9 \\
\hline 326.5 & Ss & 8.55 & 10.08 & 10.06 & 1.99 & 3.74 & 465.3 \\
\hline 334.2 & S1 tst & 7.42 & 8.52 & & 3.30 & & 4665.3 \\
\hline 340.2 & Sltst & 8.21 & 8.27 & 8.37 & 1.70 & 3.39 & 4493.4 \\
\hline 346.3 & Cgl & 9.98 & 11.94 & & 6.58 & & 4812.5 \\
\hline 349.3 & Sh & 4.72 & 4.82 & 4.84 & 0.67 & 2.85 & 4460.4 \\
\hline 586.2 & Sh & 3.33 & 3.31 & 3.31 & 3.72 & 5.42 & 4174.8 \\
\hline 589.2 & sltst & 7.48 & 7.91 & 7.81 & 1.69 & 2.30 & 4495.5 \\
\hline
\end{tabular}




\begin{tabular}{|c|c|c|c|c|c|c|c|}
\hline \multirow[b]{2}{*}{$\begin{array}{l}\text { Depth } \\
\text { (m) }\end{array}$} & \multirow[b]{2}{*}{ Lithology } & \multirow[b]{2}{*}{$K($ dry $)$} & \multicolumn{2}{|c|}{ Thermal Conductivity } & \multicolumn{2}{|c|}{ Porositya } & Sonic Velocityb \\
\hline & & & $\begin{array}{c}K(\text { wet }) \\
\text { Vacuum satur. } \\
\text { (mcal } / \mathrm{cm}\end{array}$ & $\begin{array}{c}K(\text { wet) } \\
\text { 16-day atm. satur. } \\
\left.e c^{\circ} \mathrm{c}\right)\end{array}$ & $\begin{array}{c}\text { Vacuum } \\
\text { satur. } \\
(\%) \\
\end{array}$ & $\begin{array}{l}\text { 16-day atm. } \\
\text { sa tur. } \\
\text { (\%) }\end{array}$ & $(\mathrm{m} / \mathrm{sec})$ \\
\hline & & Bowse & we11, Clarion & County, Pennsylvania & Icontinu & & \\
\hline & & & Wile well, $\mathrm{Cl}$ & rion County, Pennsyl & vania & & \\
\hline 257.6 & sitst & 8.28 & 8.72 & 8.99 & 0.92 & 2.24 & 4293.1 \\
\hline 260.9 & Ss & 8.91 & 11.17 & & 8.08 & & 4010.6 \\
\hline 279.2 & Sh & 3.53 & 3.46 & 3.47 & 1.15 & 3.34 & 4449.8 \\
\hline 283.8 & Ss & 7.56 & 8.87 & & 3.15 & $\cdots$ & 4354.4 \\
\hline 294.6 & $\mathrm{Cg} 1$ & 10.02 & 11.40 & & 4.30 & & 5277.9 \\
\hline 295.4 & Ss & 9.63 & 10.17 & & 2.57 & & 2902.9 \\
\hline 291.1 & $\mathrm{Cg} 1$ & 7.62 & 8.35 & -- & 1.22 & 1.22 & 2930.7 \\
\hline 311.5 & Cg1 & 12.69 & 12.81 & & 3.24 & & 4827.1 \\
\hline 312.7 & Cgl & 10.78 & 11.84 & 11.71 & 2.10 & 3.12 & 4876.8 \\
\hline 315.0 & Ss & 9.92 & 11.63 & & 5.83 & & 4618.3 \\
\hline 334.7 & Ss & 7.79 & 8.53 & 8.56 & 2.76 & 3.53 & 4218.7 \\
\hline 337.1 & Sh & 4.73 & 4.75 & --- & 5.55 & -- & 4800.0 \\
\hline
\end{tabular}

aThe cut-off porosity with the vacuum-saturation method is $2.5 \%$ Fourteen of the 18 samples having porosities of less than $2.5 \%$ showed a mean increase in porosity of $2.87 \%$ when saturated under atmospheric pressure for 16 days.

bThe mean of the 1-ft and 3-ft spacing values on the sonic-velocity logs was used. 


\section{APPENDIX $K$}

\section{RADIOGENIC ELEMENTS AND HEAT PRODUCTION IN CORE AND OUTCROP SAMPLES FROM OHIO, PENNSYLVANIA, AND NEW JERSEY}




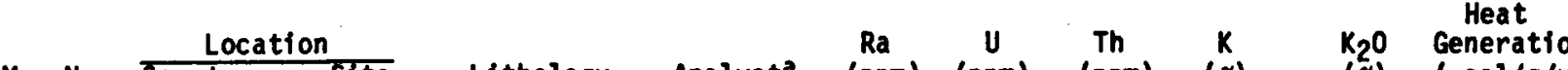

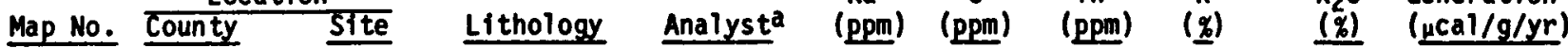

OHIO

\begin{tabular}{|c|c|c|c|c|c|c|c|c|c|c|}
\hline \multirow[t]{5}{*}{1} & Summit & Barberton & Shale & 1 & & 2.10 & 11.4 & 4.98 & & 3.83 \\
\hline & & & Shale & 1 & & 1.00 & $<0.9$ & 8.19 & & $<0.93$ \\
\hline & & & Shale & 1 & & 2.58 & 13.4 & 5.07 & & 4.58 \\
\hline & & Shale & 1 & & 2.80 & 9.8 & 3.28 & & 4.01 & \\
\hline & & & Shale & 1 & & 1.48 & 8.5 & 7.48 & & 2.80 \\
\hline 2 & Fayette & & Amphibolite & 1 & & 1.60 & 1.0 & & 1.46 & 1.76 \\
\hline 3 & Morrow & Granite & & 1 & & 2.11 & 15.6 & & 5.42 & 6.12 \\
\hline 4 & Morrow & & Pegmatite & 1 & & 3.54 & 1.06 & & 2.03 & 3.34 \\
\hline
\end{tabular}

PENNSYLVANIA

\begin{tabular}{|c|c|c|c|c|c|c|c|c|c|c|}
\hline \multirow[t]{6}{*}{5} & Clarion & Bowser & Shale & 1 & & 4.41 & 16.3 & 2.23 & & 7.10 \\
\hline & & & Shale & 1 & & 3.75 & 16.8 & 2.62 & & 6.81 \\
\hline & & & Shale & 1 & & 2.97 & 12.3 & 2.37 & & 5.27 \\
\hline & & & Shale & 1 & - & 3.62 & 14.5 & 2.79 & & 6.29 \\
\hline & & & Shale & 1 & & 4.01 & 17.3 & 3.13 & & 7.23 \\
\hline & & & Silt & & & 4.52 & 20.3 & 2.04 & & 7.91 \\
\hline 6 & Venango & Bankson & Shale & 1 & & 3.67 & 16.3 & 2.92 & & 6.73 \\
\hline \multirow[t]{2}{*}{7} & & Reed & Shale & 1 & & 3.82 & 14.9 & 2.82 & & 6.53 \\
\hline & & & Shale & 1 & & 4.10 & 15.4 & 2.87 & & 6.85 \\
\hline \multirow[t]{2}{*}{8} & Clarion & Wile & Shale & 1 & & 3.73 & 15.5 & 2.48 & & 6.49 \\
\hline & & & & & & 3.41 & 14.5 & 3.05 & & 6.21 \\
\hline 9 & Erie & & $\begin{array}{r}\text { Quartz-mica } \\
\text { schist }\end{array}$ & 1 & & 3.55 & 11.12 & & 8.90 & 7.22 \\
\hline \multirow[t]{2}{*}{10} & Berks & Fleetwood & Igneous & 2 & 0.97 & & 7.54 & 3.58 & & 3.18 \\
\hline & & & Igneous & 2 & 1.63 & & 7.04 & 1.91 & & 3.11 \\
\hline 11 & & Birdsboro & Igneous & 1 & & 1.83 & 7.63 & & 5.45 & 4.33 \\
\hline \multirow[t]{3}{*}{12} & & Birdsboro & Igneous & 2 & 0.95 & & 1.27 & 4.57 & & 2.18 \\
\hline & & & Igneous & 2 & 2.87 & & 2.17 & 1.47 & & 1.93 \\
\hline & & & Igneous & 2 & 1.06 & & 0.85 & 0.47 & & 1.07 \\
\hline 13 & & Boyertown & Igneous & 2 & 0.35 & & 0.32 & 1.82 & & 0.81 \\
\hline \multirow[t]{3}{*}{14} & & Mana towny & Igneous & 2 & 1.78 & & 1.36 & 4.21 & & 2.71 \\
\hline & & & Igneous & 2 & 1.09 & & 7.31 & 3.87 & & 3.30 \\
\hline & & & Igneous & 2 & 5.38 & & 13.55 & 0.12 & & 6.67 \\
\hline 15 & $\begin{array}{l}\text { North- } \\
\text { ampton }\end{array}$ & Easton & Igneous & 1 & & 4.26 & 12.2 & & 6.43 & 7.29 \\
\hline 16 & & Easton & Igneous & 1 & & 34.67 & 15.1 & & 5.84 & 29.9 \\
\hline \multirow[t]{4}{*}{17} & & Easton & I gneous & 2 & 0.93 & & 0.06 & 0.98 & & 1.08 \\
\hline & & & Igneous & 2 & 4.01 & - & 9.32 & 2.68 & & 5.51 \\
\hline & & & Igneous & 2 & 7.92 & & 24.86 & 6.01 & & 12.38 \\
\hline & & & Igneous & 2 & 4.28 & & 12.43 & 4.60 & & 6.85 \\
\hline
\end{tabular}


-

Map No Location County Site Lithology

Analysta

$\mathrm{Ra}$

U

Th

$\mathrm{k}$

Heat

18 Bucks Riegels-

19

ville
Riegels-
ville

Igneous

1

$0.86<1.0$

$5.84<2.38$

Igneous

0.67

\begin{tabular}{ll}
$0.36 \quad 3.23$ \\
\hline
\end{tabular}

1.43

Igneous

0.30

$0.34 \quad 1.59$

0.72

Igneous

0.22

$0.27 \quad 3.40$

1.13

New Jersey

\begin{tabular}{|c|c|c|c|c|c|c|c|c|c|}
\hline \multirow[t]{7}{*}{20} & \multirow[t]{7}{*}{ Sussex } & \multirow[t]{7}{*}{ Franklin } & \multirow[t]{7}{*}{ Igneous } & 2 & 0.09 & 0.07 & 0.7 & & 0.27 \\
\hline & & & & 2 & 2.17 & 4.54 & 2.09 & & 3.06 \\
\hline & & & & 2 & 5.51 & 15.88 & 3.81 & & 8.23 \\
\hline & & & & 2 & 3.02 & 4.28 & 6.34 & & 4.77 \\
\hline & & & & 2 & 1.52 & 0.97 & & 2.26 & 1.91 \\
\hline & & & & 2 & 0.89 & 0.46 & & 4.71 & 2.01 \\
\hline & & & & 2 & 0.42 & 0.19 & & 4.50 & 1.56 \\
\hline 21 & \multirow[t]{11}{*}{ Morris } & Dover & Igneous & 2 & 9.22 & 28.93 & 4.44 & & 13.72 \\
\hline 22 & & Mendham & Igneous & 2 & 0.10 & 0.15 & 1.51 & & 0.51 \\
\hline \multirow[t]{9}{*}{23} & & Boonton & Igneous & 2 & 3.15 & 14.92 & 3.86 & & 6.33 \\
\hline & & & Igneous & 2 & 3.65 & 26.15 & 3.25 & & 8.77 \\
\hline & & & Igneous & 2 & 1.00 & 9.07 & 2.38 & & 3.19 \\
\hline & & & Igneous & 2 & 0.13 & 3.76 & 0.84 & & 1.07 \\
\hline & & & Igneous & 2 & 0.94 & 1.49 & 4.91 & & 2.31 \\
\hline & & Blue & Igneous & 2 & 0.61 & 0.45 & & 4.70 & 1.80 \\
\hline & & & Igneous & 2 & 3.00 & 6.89 & & 3.69 & 4.56 \\
\hline & & & Igneous & 2 & 1.09 & 11.66 & & 3.78 & 4.15 \\
\hline & & & Igneous & 2 & 0.87 & 4.24 & & 1.83 & 1.98 \\
\hline
\end{tabular}

$a_{1}=$ Los Alamos Mational Laboratory

$2=U$. S. Geological Survey 